\title{
THE DEEP STRUCTURE AND PALEOGEODYNAMICS OF SIBERIA AND CENTRAL ASIA IN STUDIES OF THE INSTITUTE OF THE EARTH'S CRUST, SB RAS (2009-2013)
}

\author{
D. P. Gladkochub, E. Kh. Turutanov \\ Institute of the Earth's Crust SB RAS, Irkutsk, Russia
}

\begin{abstract}
The deep structure and paleogeodynamics of the Siberian craton and the Central Asian folded belt are studied by two specialized laboratories of the Institute of the Earth's Crust, SB RAS - the Laboratory of Complex Geophysics and the Laboratory of Paleogeodynamics. A variety of modern geophysical methods is applied. Surface wave tomography is focused on determination of 3D velocity structure of the upper mantle. Seismic, gravimetric and electrical surveys are aimed at studies of structures of the crust and the upper mantle. Geothermic parameters of the lithosphere in Central Asia are measured. In search for mineral resources, new geophysical prospecting technologies are developed. Quality paleogeodynamics reconstructions require a proper understanding of the structural evolution of the Siberian craton and the Central Asian folded belt. Researches in this scientific field are conducted by the Laboratory of Paleogeodynamics. Besides, the Laboratory studies new minerals and conditions of their formation. Some of the scientific research projects are jointly implemented by the two laboratories, and research results are regularly published in Russia and abroad.
\end{abstract}

Key words: deep structure, tectonics, paleogeodynamics, Siberian craton, Central Asian folded belt, upper mantle, crust, surface wave tomography, gravimetric method, electrical survey, geodynamic reconstructions.

Citation: Gladkochub D.P., Turutanov E.Kh. 2014. The deep structure and paleogeodynamics of Siberia and Central Asia in studies of the Institute of the Earth's Crust, SB RAS (2009-2013). Geodynamics \& Tectonophysics 5 (1), 41-80. doi:10.5800/GT-2014-5-1-0117.

\section{ГЛУБИННОЕ СТРОЕНИЕ И ПАЛЕОГЕОДИНАМИКА СИБИРИ И ЦЕНТРАЛЬНОЙ АЗИИ В РАБОТАХ ИНСТИТУТА ЗЕМНОЙ КОРЫ СО РАН (2009-2013 ГГ.)}

\author{
Д. П. Гладкочуб, Е. Х. Турутанов
}

Институт земной коры СО РАН, Иркутск, Россия

Аннотация: Изучением глубинного строения и палеогеодинамики Сибирского кратона и Центрально-Азиатского складчатого пояса занимаются две специализированные лаборатории ИЗК СО РАН: лаборатория комплексной геофизики и лаборатория палеогеодинамики. Использование геофизических методов в рамках данной тематики ориентировано на определение трехмерной скоростной структуры верхней мантии методом поверхностно-волновой томографии, изучение строения земной коры и верхней мантии сейсмическими, гравиметрическими и электроразведочными методами, измерение геотермических параметров литосферы Центральной Азии и разработку новых технологий поиска месторождений полезных ископаемых. Выполнение качественных палеогеодинамических реконструкций требует расшифровки сценария становления структуры Сибирского кратона и Центрально-Азиатского складчатого пояса. Исследованием этой проблемы занимаются сотрудники лаборатории палеогеодинамики. Отдельным направлением в данной лаборатории является изучение новых минералов и выяснение условий их образования. Сотрудни- 
D.P. Gladkochub, E.Kh. Turutanov: The deep structure and paleogeodynamics of Siberia and Central Asia...

ки лабораторий ведут скоординированные научные исследования, результаты которых активно публикуются в ведущих российских и зарубежных научных изданиях.

Ключевые слова: глубинное строение, тектоника, палеогеодинамика, Сибирский кратон, Центрально-Азиатский складчатый пояс, верхняя мантия, земная кора, поверхностно-волновая томография, гравиметрический метод, электроразведка, геодинамические реконструкции.

\section{1. ВВЕДЕНИЕ}

Объединение научных коллективов двух лабораторий в рамках общей научной тематики продиктовано тем обстоятельством, что современное глубинное строение земной коры, наблюдаемое в геофизических полях, во многом обусловлено тектоническими процессами далекого геологического прошлого, которые являются предметом изучения специалистов в области палеогеодинамики.

Успешное научное сотрудничество двух этих лабораторий реализуется в рамках общей тематики (проекта) НИР, обозначенной как «Глубинное строение и геодинамическая эволюция южного фланга Сибирского кратона и прилегающих областей Центрально-Азиатского складчатого пояса», финансируемой из госбюджета. В общероссийском плане эти исследования отвечают Приоритетному направлению развития фундаментальной науки в РФ № VIII.66. «Геодинамические закономерности вещественно-структурной эволюции твердых оболочек Земли».

Каждая лаборатория, вовлеченная в общую тематику, имеет свою историю, основные научные направления, методы исследования и наиболее значимые научные достижения. Сотрудники лабораторий ведут скоординированную научно-организационную деятельность и имеют определенные заслуги, признаваемые на уровне как региона, так и всей страны. Эти вопросы будут детально рассмотрены далее в тексте статьи.

\section{2. ГЛУБИННОЕ СТРОЕНИЕ СИБИРИ И ЦЕНТРАЛЬНОЙ АЗИИ (ЛАБОРАТОРИЯ КОМПЛЕКСНОЙ ГЕОФИЗИКИ)}

Лаборатория комплексной геофизики создана в 1970 г. для выполнения научно-исследовательских работ с целью изучения строения коры и мантии центральной части Азии комплексом геофизических методов, включая сейсмические, гравиметрические, электро-, магнитометрические и геотермические. Основателем и руководителем лаборатории с 1970 по 2008 г. был д.г.-м. н., профессор, заслуженный деятель науки РФ Ю.А. Зорин (рис. 1). Основными задачами лаборатории являются получение новых фундаментальных знаний по теме: «Строение и термический режим зем- ной коры и мантии под тектонически активными регионами центральной части Азии» и применение их в практике. Коллектив лаборатории - 17 человек, в том числе 3 доктора и 7 кандидатов наук (рис. 2).

Основные направления деятельности лаборатории:

- определение трехмерной скоростной структуры верхней мантии центральной части Азии методом поверхностно-волновой томографии;

- изучение строения земной коры и верхней мантии Байкало-Монгольского региона комплексом геофизических методов;

- изучение геотермических параметров литосферы центральной части Азии;

- разработка новых технологий поиска месторождений полезных ископаемых.

Аппаратурно-приборная база лаборатории состоит из гравиметров ГНУ-К2, оптических микробарометров, измерителей теплофизических свойств горных пород и минералов, кондуктометра «Эксперт-002», вольтметров, сейсмометров.

Далее представлены основные научные достижения лаборатории за 2009-2013 гг. (по направлениям).

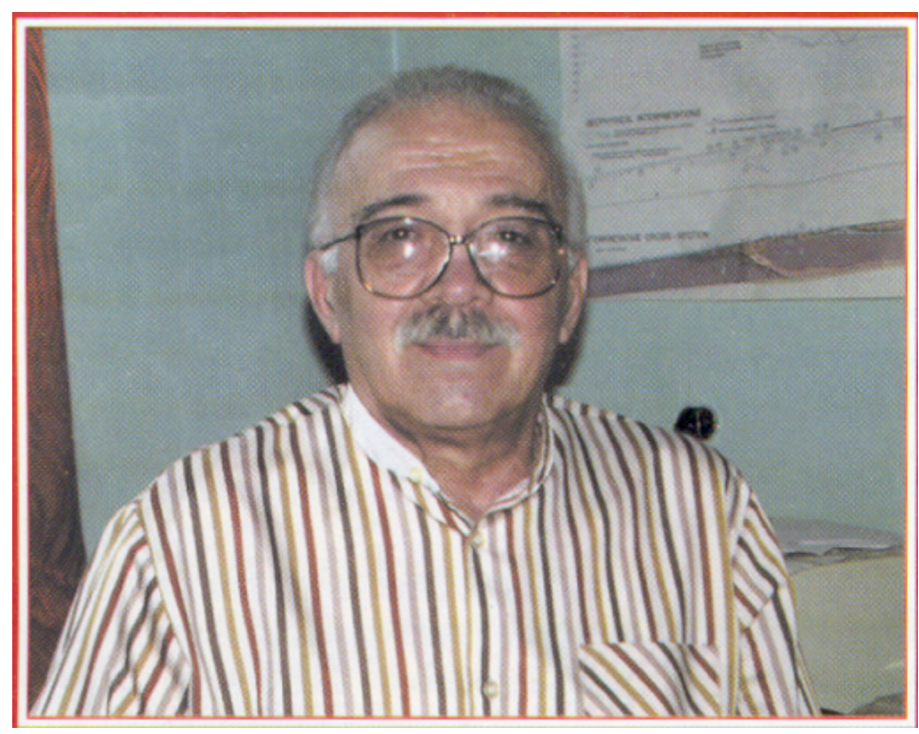

Рис. 1. Профессор Ю.А. Зорин.

Fig. 1. Prof. Yu.A. Zorin. 


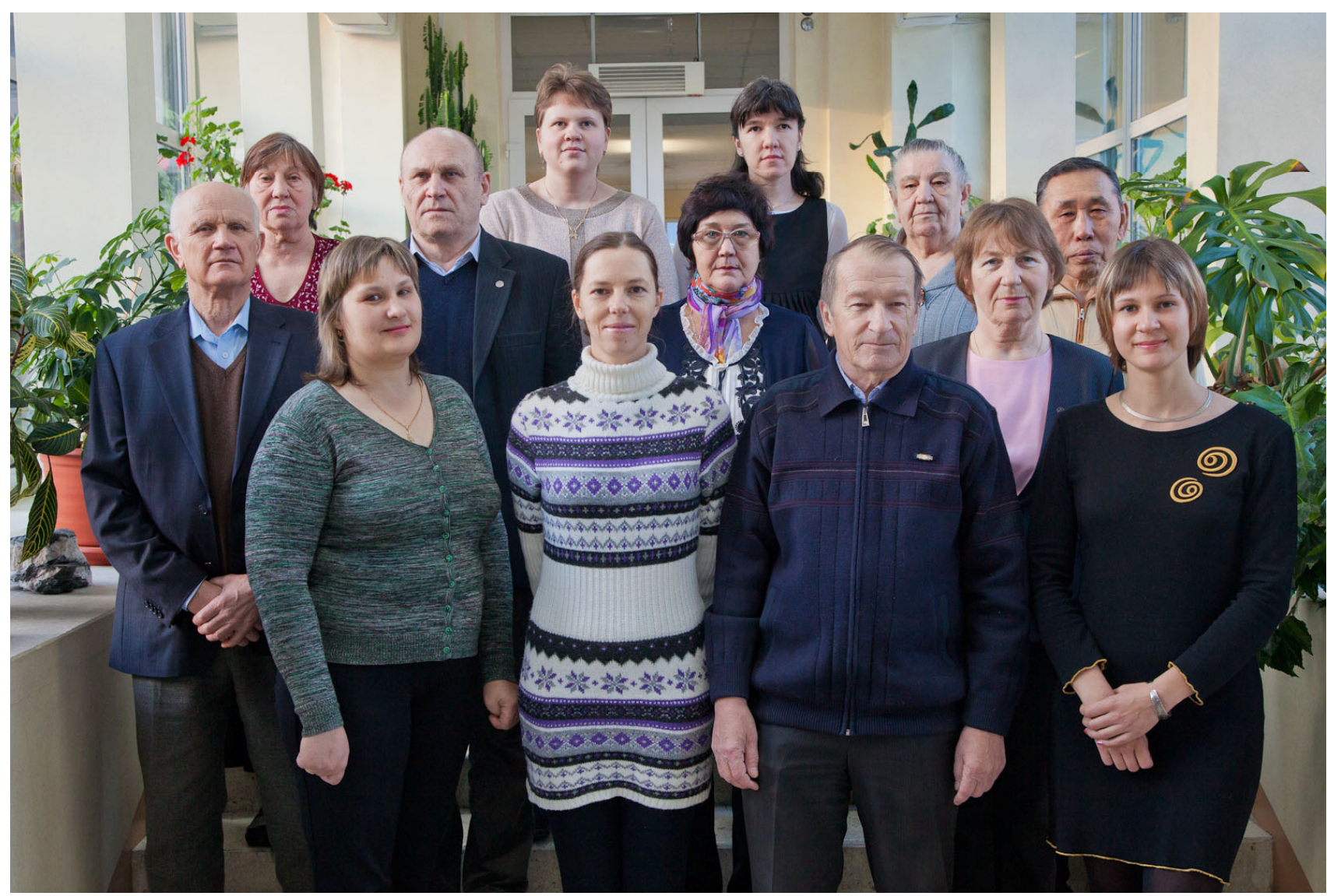

Рис. 2. Сотрудники лаборатории комплексной геофизики.

Нижний ряд (слева направо): Н.В. Татомир, к.ф.-м.н. О.А. Соловей, к.ф.-м.н. В.М. Кожевников, к.ф.-м.н. А.И. Середкина; средний ряд: д.г.-м.н. В.А. Голубев, Л.Р. Шеломенцева, к.г.-м.н. Е.Х. Турутанов - заведующий лабораторией, д.Г.-м.н. В.И. Мельникова, к.ф.-м.н. В.А. Рогожина, д.г.-м.н. В.В. Мордвинова, А.Б. Бадуев; верхний ряд: М.А. Хритова, к.г.-м.н. Н.А. Радзиминович.

Fig. 2. The Laboratory of Complex Geophysics.

$1^{\text {st }}$ row - N.V. Tatomir, O.A. Solovei, A.I. Seredkina; $2^{\text {nd }}$ row - V.A. Golubev, L.R. Shelomentseva, E.Kh. Turutanov (Head of the Laboratory), V.I. Mel'nikova, V.A. Rogozhina, V.V. Mordvinova, A.B. Baduev; $3^{\text {rd }}$ row - M.A. Khritova, N.A. Radziminovich.

\section{1. ОПРЕДЕЛЕНИЕ ТРЕХМЕРНОЙ СКОРОСТНОЙ СТРУКТУРЫ ВЕРХНЕЙ МАНТИИ ЦЕНТРАЛЬНОЙ ЧАСТИ АЗИИ МЕТОДОМ ПОВЕРХНОСТНО-ВОЛНОВОЙ ТОМОГРАФИИ}

Эти исследования выполнены по данным дисперсии фазовых скоростей основной моды волн Рэлея на участках между парами регистрирующих станций. Исходными материалами при этом служили записи волн Рэлея от землетрясений каналами LHZ широкополосных станций GSN азиатских сетей IRIS с цифровой регистрацией сейсмических сигналов. Эпицентры выбранных землетрясений с магнитудами, равными 6.0 и более, в подавляющем большинстве случаев располагались на значительном удалении от регистрирующих станций - в пределах бассейнов и на островах Тихого, Индийского и Атлантического океанов, а также в прибрежных зонах Северной, Центральной и Южной Америки. Эпицентральные расстояния при этом изменялись от 7000 до 15000 км, и глубина исследований сре- ды, соответственно, близка к 600-650 км [Кожевников, Соловей, 2010]. Полученные дисперсионные кривые групповых и фазовых скоростей были использованы в качестве исходных данных при восстановлении трехмерной скоростной структуры верхней мантии Азии методом поверхностно-волновой томографии. В общем случае всего было получено 12 карт для глубин от 50 до 600 км с шагом по глубине 50 км и двумерные скоростные разрезы, пересекающие основные тектонические структуры исследуемой области. Некоторые карты распределения скоростей волн $\mathrm{S}$ приведены на (рис. 3). На основе полученных трехмерных моделей распределения скоростей поперечных волн в верхней мантии Азии были построены двумерные скоростные разрезы, пересекающие основные тектонические структуры континента и отражающие особенности глубинного строения верхней мантии региона (рис. 4).

На основании анализа результатов картирования и двумерных скоростных разрезов сделано заключение, 

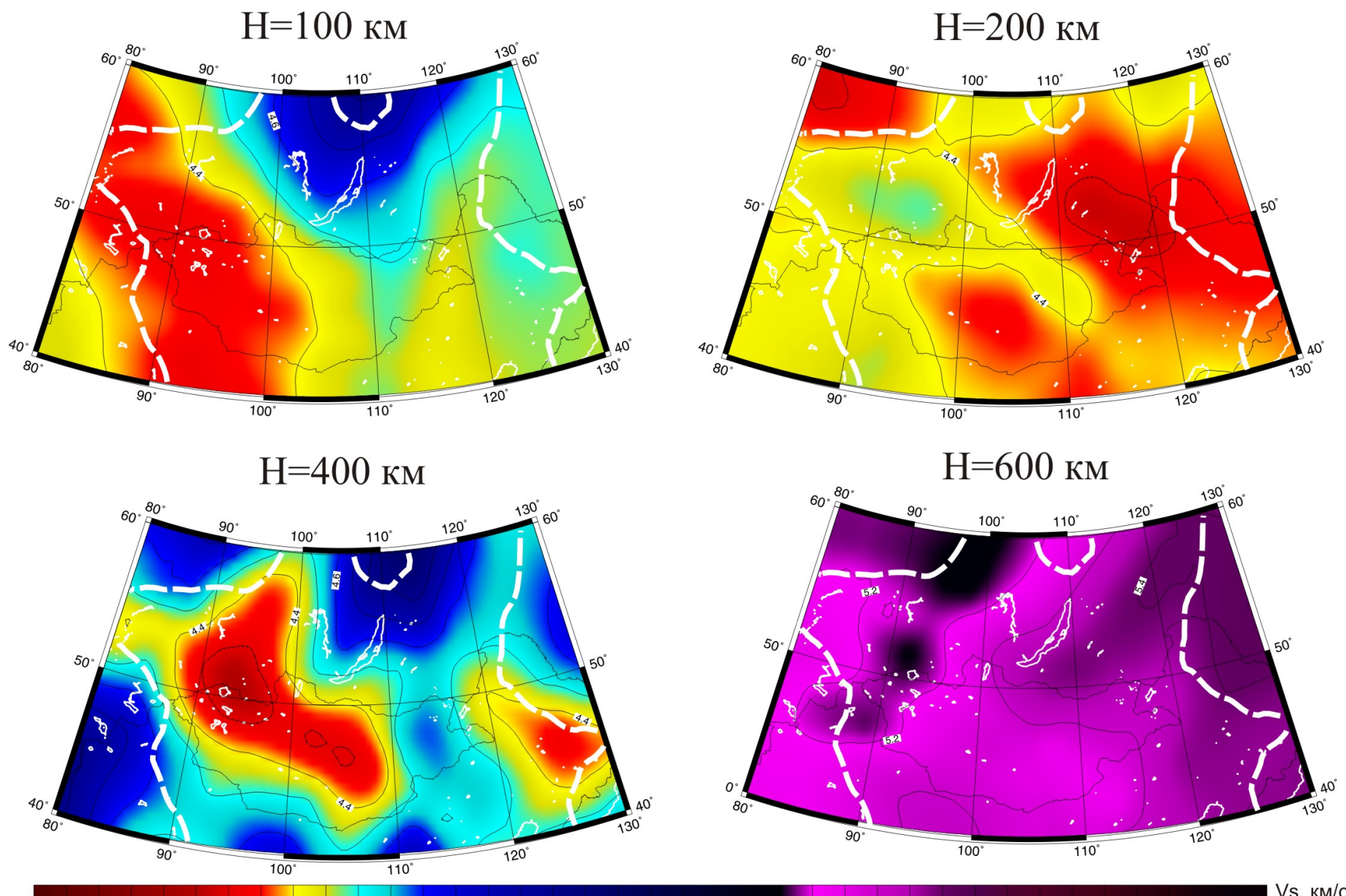

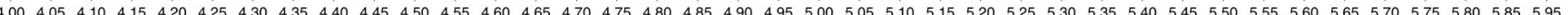

Рис. 3. Некоторые карты распределения скоростей поперечных сейсмических волн в мантии области исследования.

Н - глубина соответствующей сферической поверхности, белый пунктир - границы области исследований.

Fig. 3. Sample maps showing patterns of transversal seismic wave velocities in the mantle in the area under study.

$\mathrm{H}$ - depth of the corresponding spherical surface. The area under study is marked by the white contour.

что верхняя мантия центральной части Азии характеризуется неоднородностью глубинного строения на всем интервале исследуемых глубин. Наиболее существенные по перепаду сейсмических скоростей неоднородности наблюдаются в пределах верхних 400 км мантии. Толщина литосферы при этом варьируется в широких пределах - от приблизительно 50-60 км под тектонически активными высокогорными регионами Южной Сибири и Западной Монголии до 200-250 км под Сибирской платформой. Наличие низкоскоростных слоев и включений на глубинах порядка 400 км, а также высокоскоростных включений в пределах транзитной зоны на востоке и юго-востоке области исследования может быть обусловлено совокупностью эндогенных процессов, проявившихся в мантии центральной части Азии, включая воздействие глубинных плюмов [Кожевников, Соловей, 2010]. В пользу такого вывода свидетельствуют и результаты глобальной сейсмической томографии, базирующиеся на невязках времен пробега продольных сейсмических волн, полученные другими исследователями.

\section{2. ИЗУЧЕНИЕ СТРОЕНИЯ ЗЕМНОЙ КОРЫ И ВЕРХНЕЙ МАНТИИ БАЙКАЛО-МОНГОЛЬСКОГО РЕГИОНА КОМПЛЕКСОМ ГЕОФИЗИЧЕСКИХ МЕТОДОВ}

\subsection{1. Исследования с помощью телесейсмических записей}

Данные исследования выполнены с использованием сейсмической сети эксперимента PASSCAL 1991-1992 и MOBAL-2003 [Мордвинова, Артемьев, 2010]. Для каждой сейсмостанции рассчитаны одномерные скоростные модели $V s(h)$ от поверхности до глубины 70 км, а на их базе построены три скоростных разреза, пересекающие Байкальскую впадину (рис. 5), и модель трехмерной скоростной структуры Южно-Байкальского района. Построенные модели свидетельствуют о локальном утонении земной коры под Южной Байкаль- 


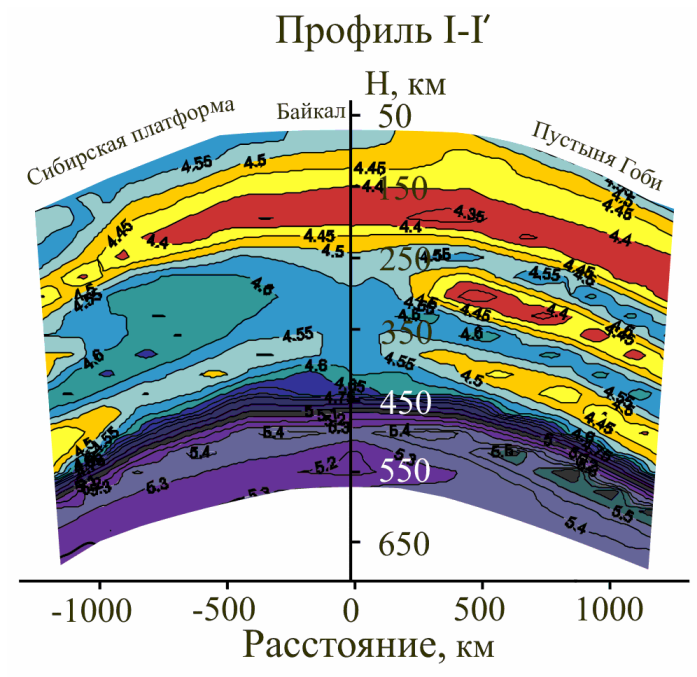

Профиль III-III'

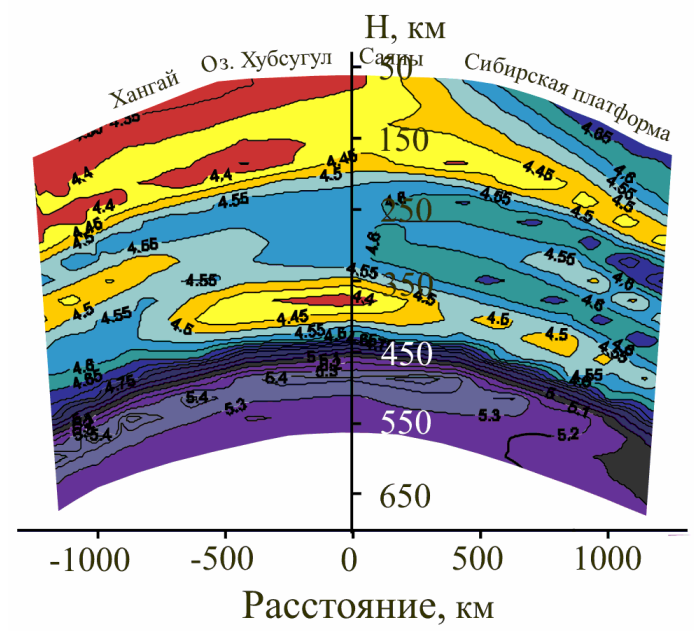

Профиль II-II'

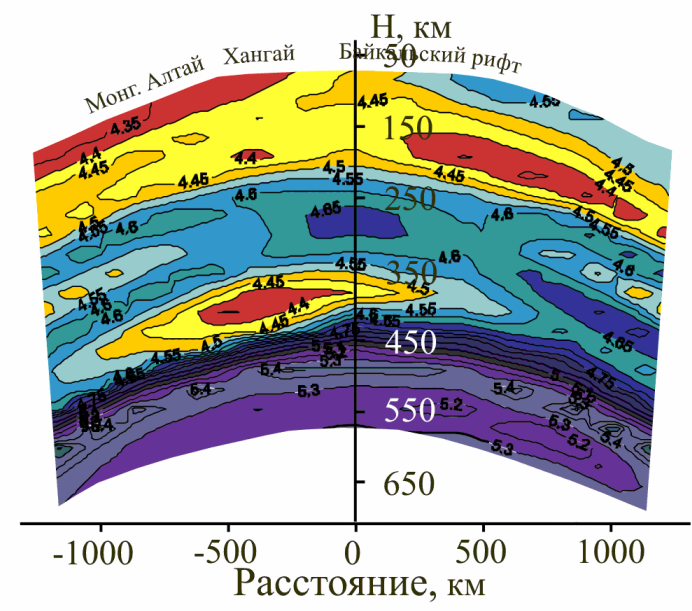

Профиль IV-IV'

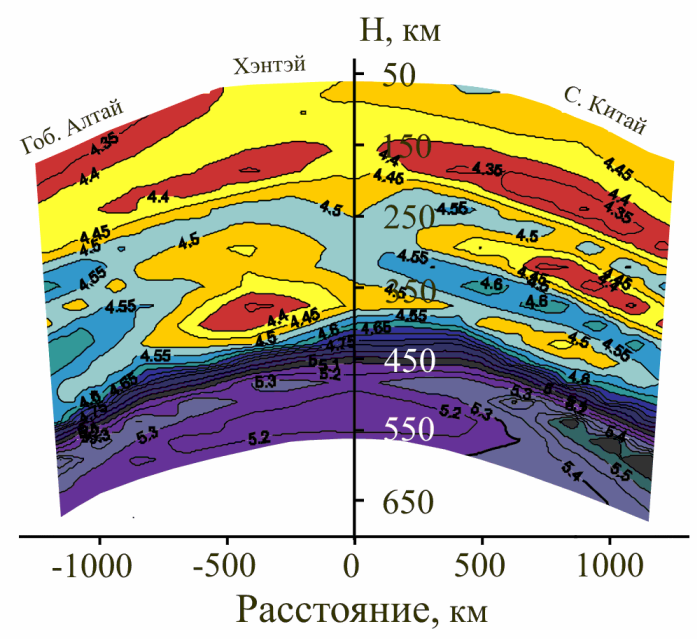

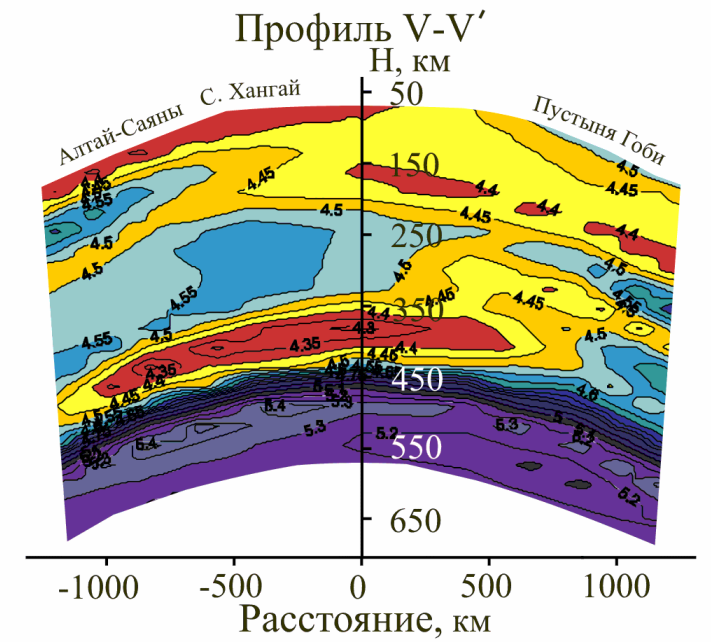

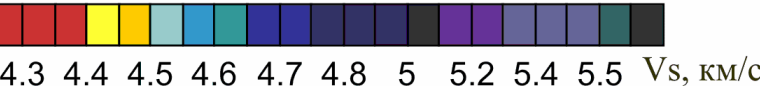

Рис. 4. Скоростные разрезы волн S.

$\mathrm{H}$ - расстояние от земной поверхности, горизонтальная ось - расстояние от средних точек профилей.

Fig. 4. Profiles of wave velocity, S.

$\mathrm{H}$ - distance to the ground surface. Distances from medium points of the profile are shown at the horizontal axis. 

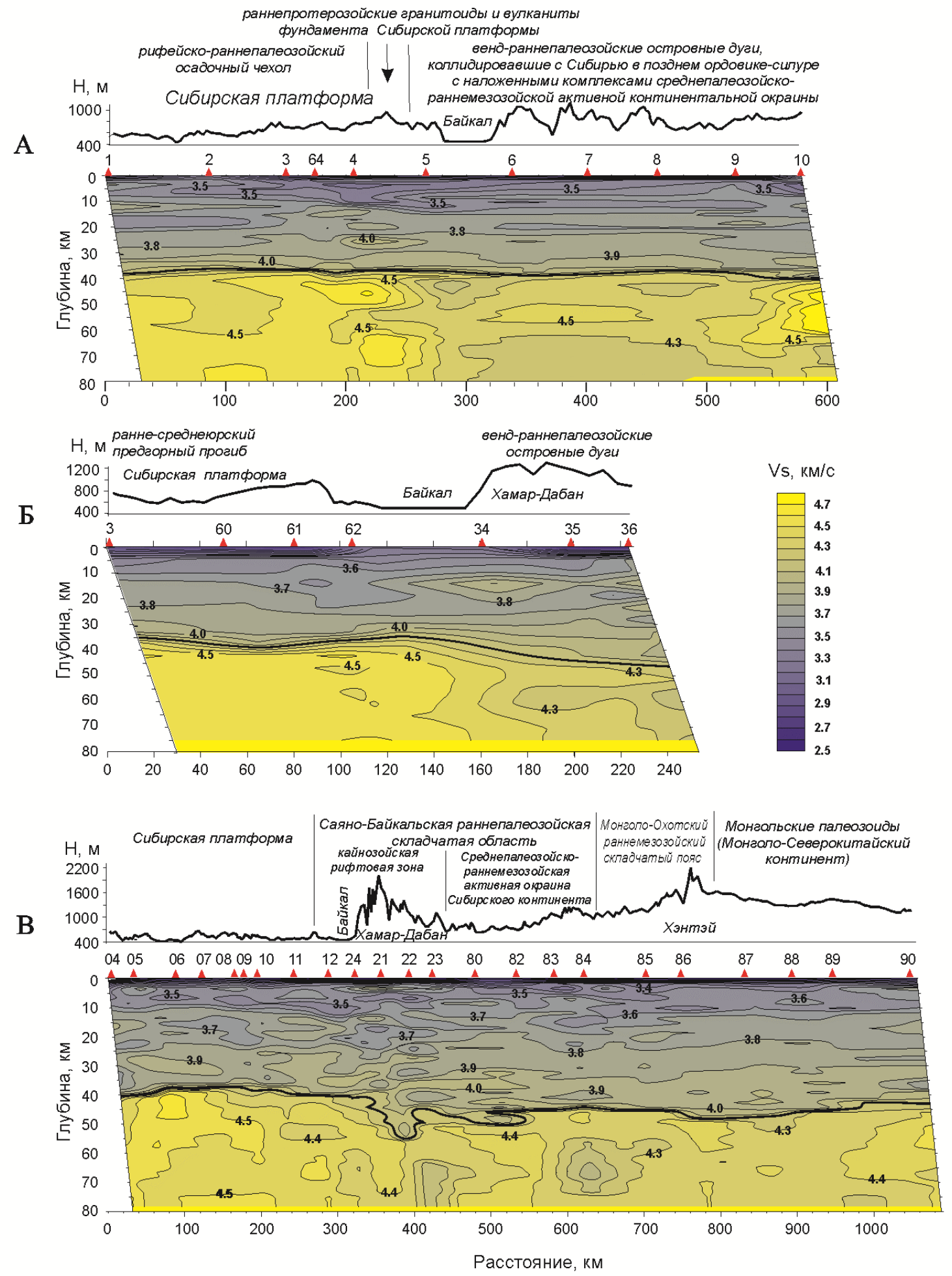

Рис. 5. Двумерные скоростные разрезы, построенные по результатам инверсии приемных функций для района Байкальского рифта и смежных регионов.

A - субширотный профиль; Б - субмеридиональный профиль по 7 станциям (1992 г.); В - субмеридиональный профиль БратскИркутск-Улан-Батор-Ундуршил. Наклон разрезов, учитывающий горизонтальный масштаб, равен углу падения (20 град.) сейсмических лучей в зондируемой толще.

Fig. 5. 2D velocity cross-sections constructed from results of receiving function inversion for the Baikal rift and neighbouring regions.

A - sublatitudinal profile; $\bar{E}$ - submeridional profile (7 stations, 1992); $B$ - submeridional profile Bratsk-Irkutsk-Ulaan Baatar-Undurshil. The cross-sections are inclined with regard to the horizontal scale at the dip angle of seismic waves in the sounded beds (20 degrees). 

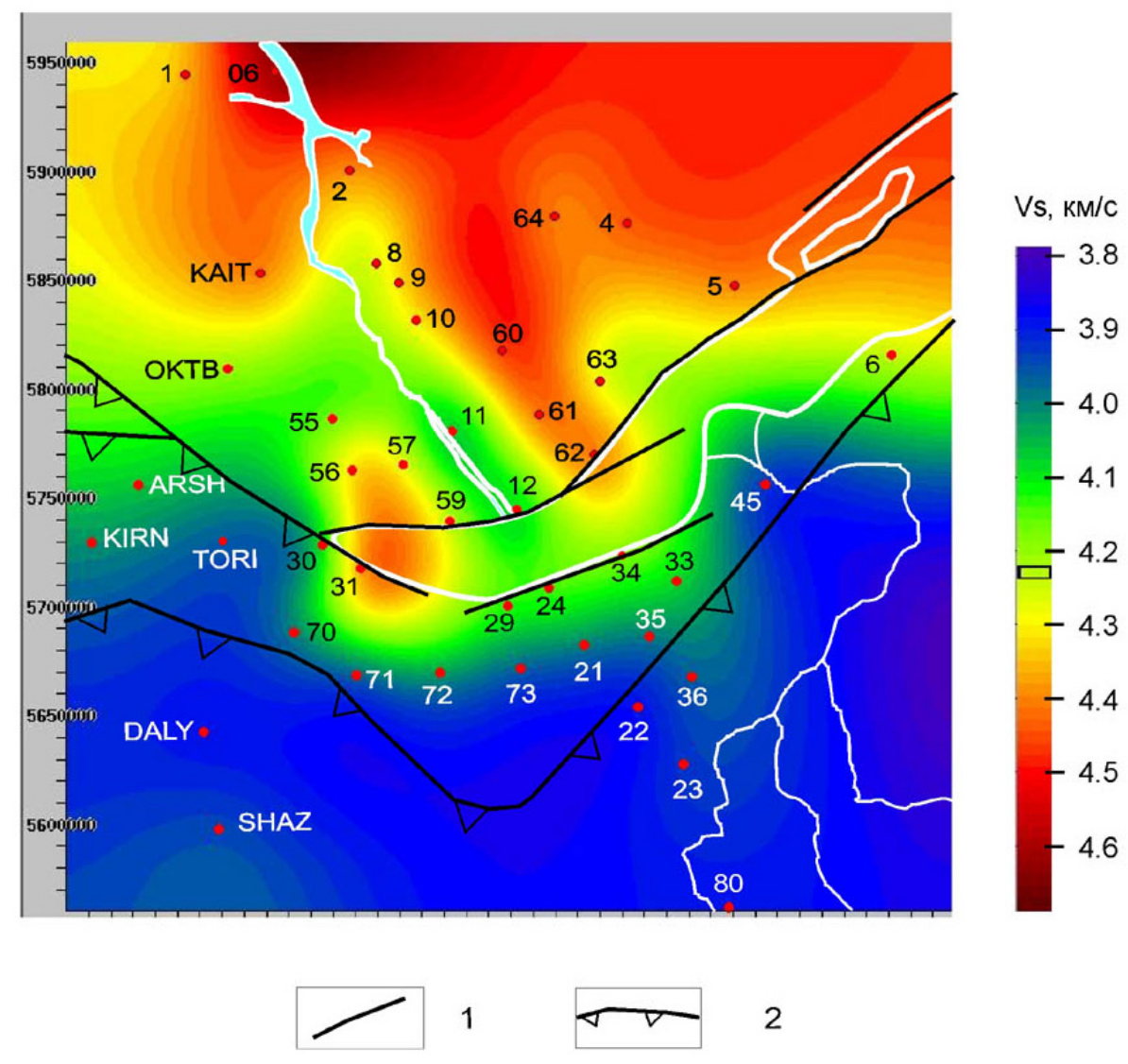

Рис. 6. Связь поверхностных геологических структур с распределением скорости S волн на глубине 39 км.

1 - сбросы, 2 - надвиги.

Fig. 6. Relationship between surface geological structure and the pattern of wave velocity, S at the depth of $39 \mathrm{~km}$.

1 - normal faults; 2 - thrusts.

ской впадиной до 34-36 км (рис. 5, станция 62), в то время как толщина коры под ее горным окружением достигает 46-50 км и даже более (под хребтами Хамар-Дабан). Понижение скоростей сейсмических волн в верхах мантии, которое обычно связывают с подъемом астеносферы, в основном приурочено к областям с наиболее толстой корой. Судя по полученным двумерным и трехмерным моделям, астеносферные выступы достигают подошвы коры не под Байкальской впадиной, а юго-восточнее, под горными хребтами, высота которых превышает 1000 м (рис. 5). Слои пониженной скорости обнаружены как под Байкальской рифтовой зоной, так и под складчатыми областями Забайкалья и Монголии, а также под Сибирской платформой. На рис. 6 показан горизонтальный срез (карта) распределения скоростей для глубины 39 км. Именно на этой глубине под Сибирской платформой и озером Байкал, судя по результатам исследований, начинается мантия, скорости которой существенно выше коровой, а южнее, под складчатыми областями, низкими скоростями проявляет себя утолщенная кора.
Исследования показали, что в земной коре скорости растут неравномерно, обнаруживая структуру с явно выраженными слоями пониженной скорости. Глубина коры на северо-западе БР3 - 36-37 км, при этом четко проявляется контрастность коромантийной границы. Южнее, под Саянами и Тункинскими гольцами, подошва коры заглубляется примерно до 50 км. Ближе к Байкалу мантия поднимается до 39 км. А восточнее и севернее выявляется утонение коры до 36 км. Модель среды под Байкалом является самой сложной на всех глубинах. Здесь высокоскоростные включения подобны набору линз несколько меньшей кривизны, чем подъем подошвы коры под Байкалом. Неоднородность коры и мантии еще более резко проявляется в аномалиях скоростей $\left(V_{S}-V_{\text {Sref }}\right) / V_{\text {Sref }}$ (рис. 7), рассчитанных в процентах по отношению к референтному скоростному разрезу $V_{\text {Sref }}(h)$. Наиболее интенсивные аномалии указывают на отличие от 40-километровой мощности коры референтной модели: положительные подкоровые аномалии подчеркивают относительно тонкую кору, отрицательные аномалии в низах коры принад- 


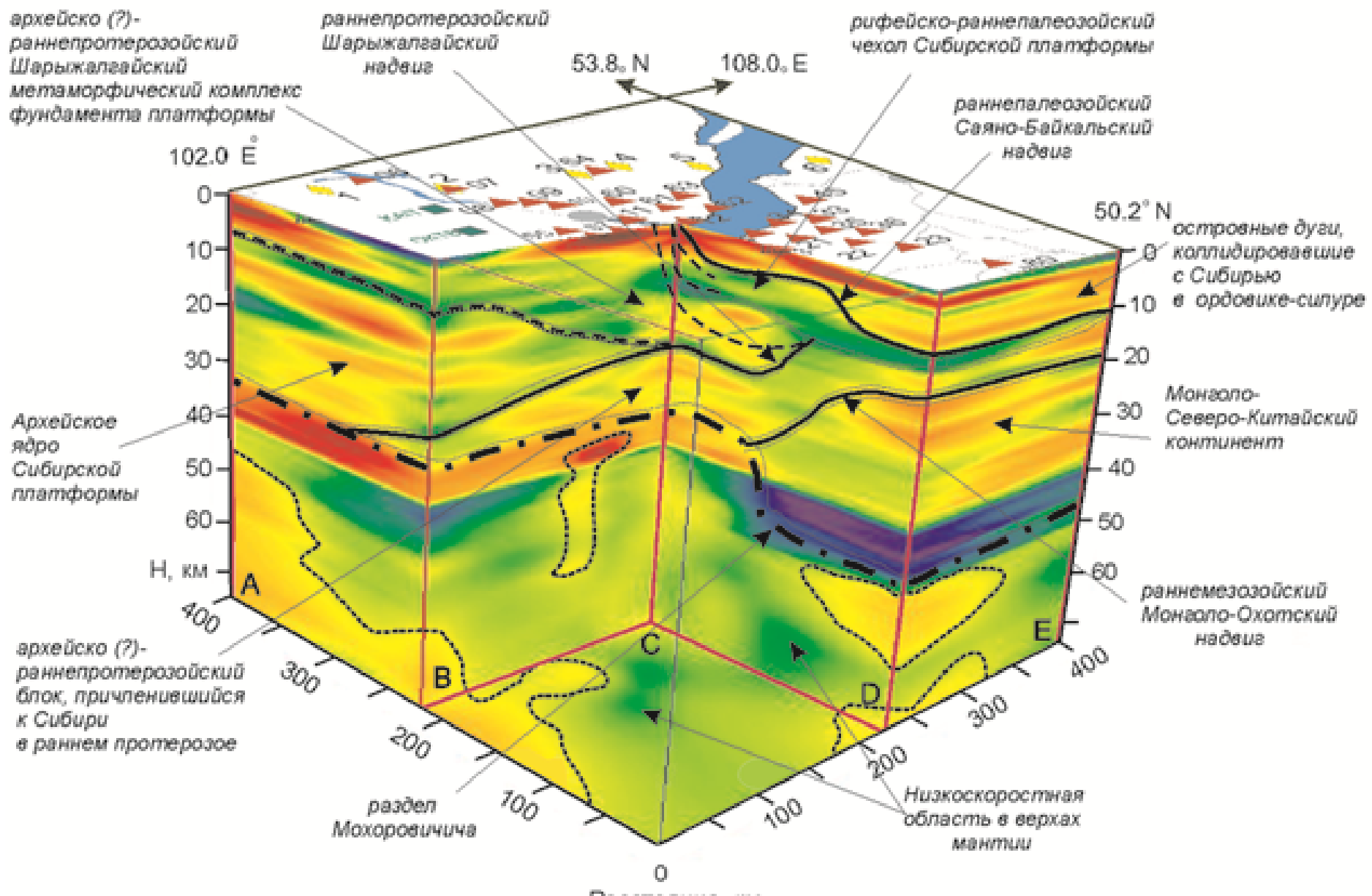

Расстояние, км

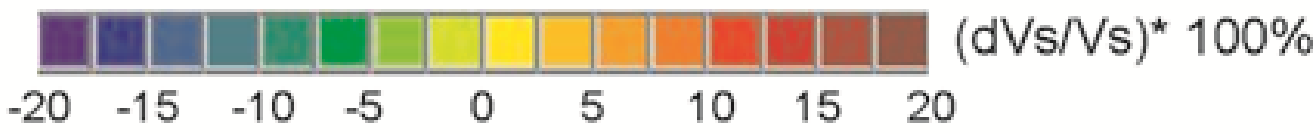

Рис. 7. Аномалии скорости распространения S волн в среде и их геологическая интерпретация: сплошными линиями обозначены надвиги первого порядка; штрихами - надвиги второго порядка; пунктиром - границы различных блоков в коре; штрих-пунктиром - раздел Мохо; тонкими штрихами оконтурена низкоскоростная область в мантии.

Fig. 7. Anomalies in propagation of wave velocity, S in the medium, and geological interpretation of such anomalies. Solid lines show the $1^{\text {st }}$ order thrusts; dotted lines show the $2^{\text {nd }}$ order thrusts; the dot-and-dash line shows the Moho discontinuity; the lowvelocity zone in the mantle is contoured by the thin dotted line.

лежат районам с земной корой толще 40 км.

Установлено, что скоростная структура земной коры БР3 неравномерна, состоит из явно выраженных слоев пониженной скорости. Неоднородность коры и мантии наиболее резко проявляется в аномалиях скоростей $\left(V_{S}-V_{\text {Sref }}\right) / V_{\text {Sref. }}$ Скоростное строение мантии тоже сложное, величина аномалий варьируется от +5 до $-5 \%$ относительно стандартной модели Земли IASP91. Положительные значения соответствуют Сибирской платформе, отрицательные значения проявляются в мантии юго-восточной части исследуемого объема.

\subsection{2. Исследования скоростной структуры по данным стационарной Байкальской сети}

Для большинства станций Байкальской сети вдоль простирания Байкальской рифтовой системы рассчитаны одномерные $\mathrm{V}_{S}$ модели до глубины 70 км, на основании которых построены соответствующие скоростные разрезы (рис. 8). Верхний разрез состоит из блоков $\mathrm{AB}, \mathrm{BC}$ и $\mathrm{CD}$, нижний - из блоков $\mathrm{ABE}$ и EFD. Блоки сформированы одномерными Vs моделями для станций, наименее удаленных от направления простирания блока. Разрешение двумерной модели меняется 


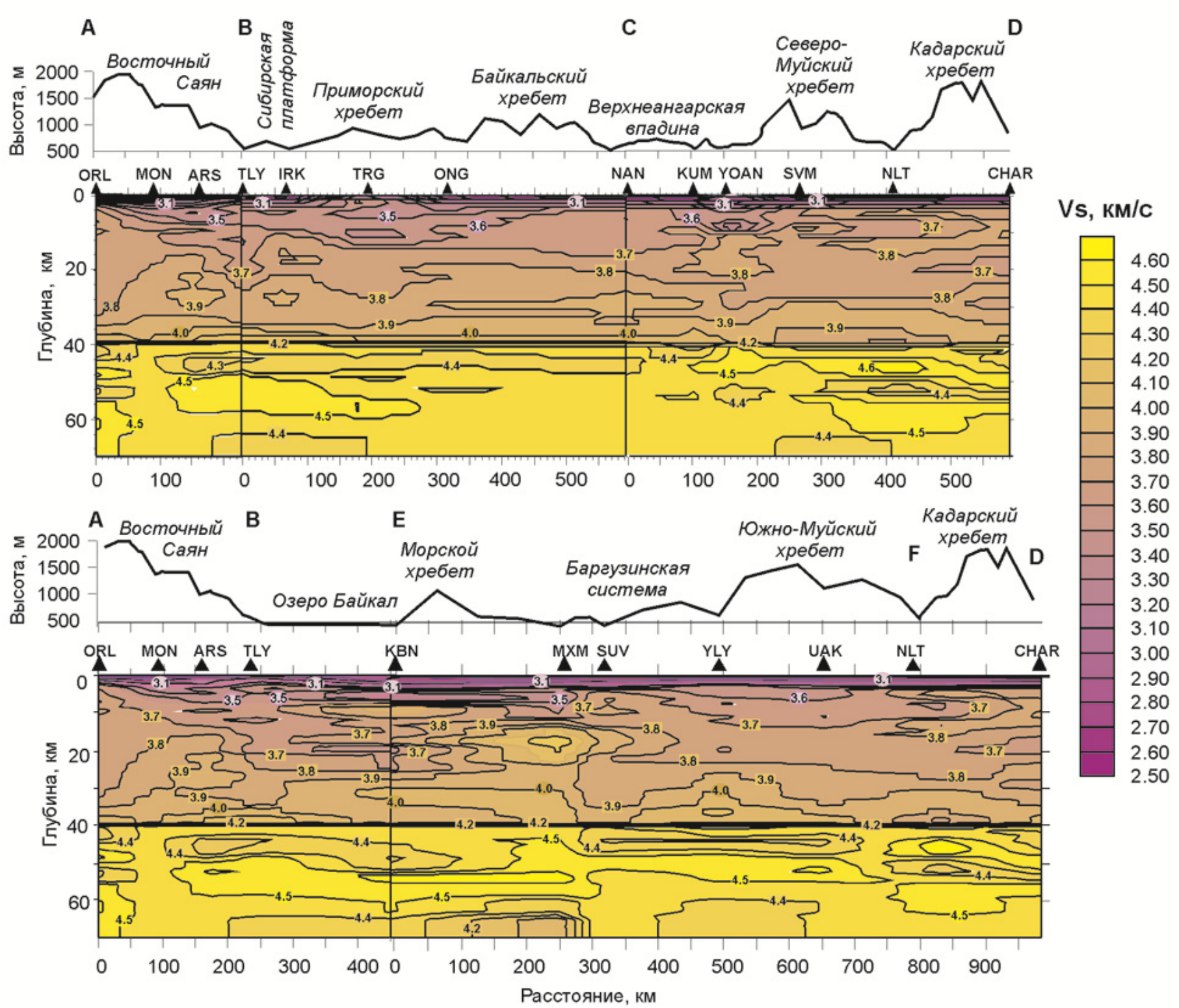

Рис. 8. Двумерный Vs разрез вдоль Байкальской рифтовой зоны.

Треугольниками отмечены позиции сейсмостанций. Изолинии в интервале скоростей от 2.0 до 4.6 км/с проведены с шагом 0.1 км/с.

Fig. 8. 2D profile Vs along the Baikal rift zone.

Triangles show locations of seismic survey stations. In the velocity range from 2.0 to $4.6 \mathrm{~km} / \mathrm{sec}$, isolines are spaced at $0.1 \mathrm{~km} / \mathrm{sec}$.

вдоль профиля в зависимости от межстанционного расстояния. В верхнем горизонте моделей низкие скорости соответствуют провисшей кровле земной коры во впадинах, заполненных осадками. Более высокие скорости относятся к межвпадинным перемычкам. Мощные низкоскоростные линзы до глубины 15 км и более могут соответствовать гранитоидам, развитым практически повсеместно вдоль рифта. Наиболее низкоскоростной является верхняя половина земной коры под Восточным Саяном (блок АВ). Обращает на себя внимание высокоскоростной блок в средней части коры в районе Уояна (YOAN, блок CD), контактирую- щий с низкоскоростным, сложным по структуре блоком в верхней части коры. Участок Кумора-Уоян-Северомуйск - это один из редких пока случаев, когда относительная густота расположения стационарных сейсмостанций и направление используемых сейсмических лучей позволяют сравнить в деталях скоростные модели, полученные телесейсмическим и локальным методами (функции приемника и ГСЗ). В верхних 20 км изолинии $V_{S}$ разреза практически повторяют изолинии $V_{P}$ по ГСЗ. На глубине, где по серии отражающих площадок по данным ГСЗ-ОГТ предполагается довольно крутопадающий разлом, на Vs разрезе 


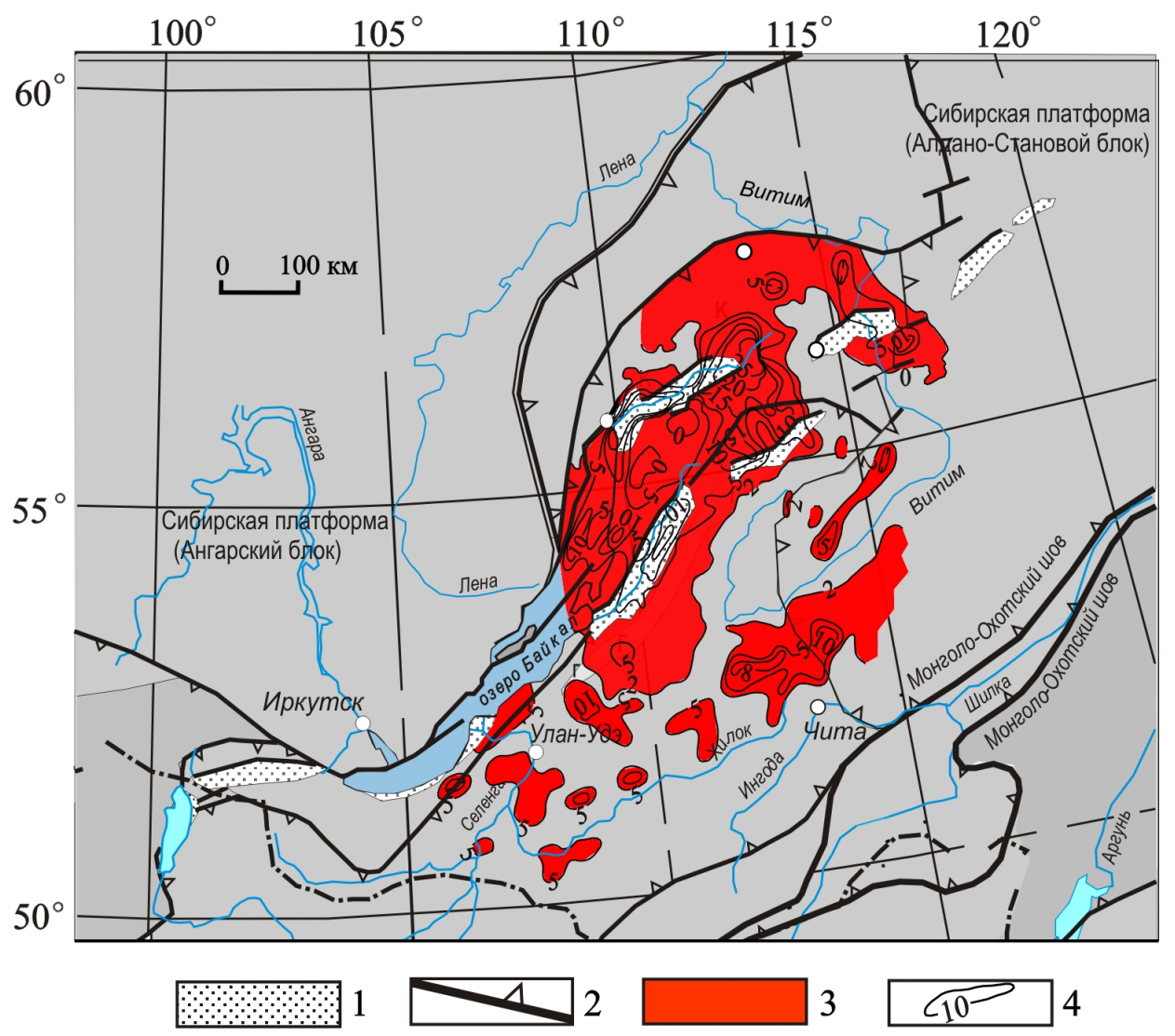

Рис. 9. Карта толщины Ангаро-Витимского плутона.

1 - позднекайнозойские рифтовые впадины; 2 - надвиги; 3 - гранитоиды Ангаро-Витимского плутона; 4 - изолинии толщины гранитоидов.

Fig. 9. The Angara-Vitim pluton thickness map.

1 - Late Cenozoic rift basins; 2 - thrusts; 3 - granitoids of the Angara-Vitim pluton; 4 -granitoid thickness isolines.

блока CD есть соответствующий излом изолинии «3.6 км». Общей чертой в моделях $V p$ (ГСЗ) и Vs (функции приемника) является и выпуклый по направлению к дневной поверхности коромантийный раздел с пониженной скоростью под ним в первых километрах кровли мантии.

Вдоль интерпретационных профилей получена практически ровная граница Мохо (на глубине 40 км). При существующем расположении станций вдоль рифтовой зоны использованные сейсмические волны, как правило, не пересекают границы Мохо ни под плечами рифта с утолщенной корой, ни под рифтовыми впадинами, под которыми вероятны и утонение коры, и градиентный переход от мантии к коре [Ананьин и др., 2009].

\subsection{3. Исследования строения земной коры Байкало- Монгольского региона по гравиметрическим данным}

Гравиметрическим методом исследованы отдельные рифтовые впадины региона и ряд интрузий кисло- го и основного состава [Турутанов, 2010, 2011a, 2011б, 2012a, 2012б]. В качестве примера рассмотрим объемную модель верхней части литосферного блока (см. рис. 7), в пределах которого расположена крупнейшая в мире позднепалеозойская-раннемезозойская Баргузино-Витимская внутриплитная магматическая область, известная как Ангаро-Витимский гранитоидный батолит [Турутанов, 2011б].

По результатам исследований, с юга и востока (рис. 9) плутон обрамлен зоной гранитизации в форме пластины со средней мощностью (толщиной) около 2-3 км, вертикальные размеры которой лишь на отдельных участках достигают 10 км. Площадь проекции плутона на земную поверхность составляет около 200 тыс. км². При ширине, достигающей 250 км, он протягивается на расстояние около 750 км. Его вертикальная мощность (толщина) составляет в среднем 8-10 км, а у истоков рек Конкудеры и Мамакана достигает 30 км.

Конфигурация плутона в какой-то мере подчиняется сети крупных разломов, которые ограничивают тела гранитоидов. К участкам пересечения разломов тяготеют утолщения плутона, которые, как правило, имеют 
линейно вытянутую форму. Последние можно рассматривать как магмоподводящие каналы, уходящие на различную глубину. В целом же глубинная форма Ангаро-Витимского плутона в первом приближении может быть сопоставима с огромной пластиной со сложнопостроенной подошвой и субгоризонтальной кровлей. Отнесение плутона к какой-то определенной форме интрузивных тел затруднительно, хотя, судя по интерпретационным разрезам, она близка к лополитообразной. Изучение глубинной геометрии Ангаро-Витимского поля гранитоидов показало, что на фоне средней толщины земной коры рассматриваемого района в 40-45 км доля гранитоидов в ее вертикальном разрезе оказывается не столь существенной, как это можно предположить из геологических данных.

\subsection{4. Исследование сейсмичности и напряженно- деформированного состояния земной коры сейсмоактивных территорий}

Были изучены крупные последовательности землетрясений (магнитуды главных толчков $M w=4.3-6.3$ ) в районах Хойтогольской, Южнобайкальской, Кичерской, Верхнеангарской и Чарской рифтовых впадин, а также редкое и достаточно сильное Балейское землетрясение $(M \mathrm{w}=4.5)$ в Восточном Забайкалье [Мельникова и др., 2009, 2011, 2013а, 2013б; Радзиминович и др., 2012; Имаева и др., 2012a, 2012б]. Распределение в земной коре гипоцентров этих сейсмических событий еще раз подтвердило сейсмогенерирующую роль средней коры (16-18 км), а разрядка напряжений в очагах осуществлялась в соответствии с сейсмотектонической обстановкой районов их локализации и господствующего деформационного режима.

Для повышения качества оценок фокальных механизмов в Байкальском регионе внедрена и протестирована методика расчета тензора сейсмического момента по амплитудным спектрам поверхностных волн [Ceредкина, Мельникова, 2013]. В дальнейшем эта методика использовалась при изучении особенностей напряженно-деформированного состояния земной коры Азиатского континента, закономерностей в проявлении сейсмичности и исследовании его глубинной структуры.

Проведенными исследованиями установлено, что большинство сильных коровых землетрясений Южной Сибири, Западной Монголии и Северного Китая происходят при пониженных скоростях поперечных волн в нижней части коры и в верхней мантии этих регионов. Сильные землетрясения на северо-востоке Байкальской рифтовой зоны приурочены к районам с высоким (около 2 \%) горизонтальным градиентом вариаций скоростей. Результаты комплексирования данных о глубинной структуре центральной части Азии и сейсмичности впервые показали, что в областях с низкоскоростной структурой верхней мантии преобладают сжимающие усилия, а в районах высокоградиент- ных скоростных аномалий - растягивающие [СередкиHa, 2013].

\subsection{5. Сейсмогравиметрические исследования земной коры}

Полученные результаты показали, что сейсмичность в регионе вызвана не физическими полями как таковыми, а непосредственно физико-геологической средой, в частности крупными плотностными неоднородностями, генерирующими эти поля. Плотностные же неоднородности характеризуются в основном вещественным составом и геометрическими особенностями слагающих их литологических комплексов, поэтому и искомые связи необходимо выявлять между сейсмичностью и указанными параметрами физикогеологической среды [Турутанов, 2011, 2012]. Достоверность предложенного подхода была проверена следующим образом (рис. 10). По результатам интерпретации гравиметрических и магнитометрических данных для Приольхонья составлена схема глубинного строения. Оказалось, что породы основного состава, геологические выходы которых картируются на побережье оз. Байкал, на глубине образуют крупный плутон, протяженность которого превышает 100 км при ширине, изменяющейся от 5 до 20 км. Плутон имеет сложную форму, а его нижняя граница расположена на глубине 4.0-7.5 км. По геофизическим данным [Турутанов, 2010, 2012б], юго-восточная часть этого тела сброшена в акваторию озера на 0.5-5.0 км при формировании Байкальской впадины и скрыта под осадками и водой. На рассматриваемую схему нанесены эпицентры землетрясений начиная с восьмого энергетического класса. Для построения карты поля эпицентров землетрясений Приольхонья использованы также данные Байкальского филиала ГС СО РАН (http://www.seisbykl.ru). Кроме того, учтены эпицентры землетрясений, выявленные по палеосейсмическим данным, и по данным локальной сети сейсмических станций Бурятского филиала ГС СО РАН [Турутанов, 2012б]. Если рассматривать ту часть основного плутона, которая по магнитометрическим данным располагается в фундаменте озера Байкал (рис. 10), то увидим, что от сопредельных участков фундамента Байкала она отличается минимальной сейсмичностью. Действительно, к юговостоку от контура проекции базитовых тел количество эпицентров значительно возрастает, а размеры участков «молчания» малы и соизмеримы с точностью определения местоположения эпицентров. К югозападу от предполагаемого окончания базитового плутона сейсмичность остается выше, чем в его пределах, хотя уровень ее несколько ниже, чем на юго-востоке.

На основе изучения глубинной геометрии интрузивных тел можно утверждать, что в распределении очагов землетрясений в Приольхонье наблюдается тенденция к уменьшению их числа на участках развития базитовых тел на побережье и под рыхлыми осадками на акватории озера Байкал. Предположительно 


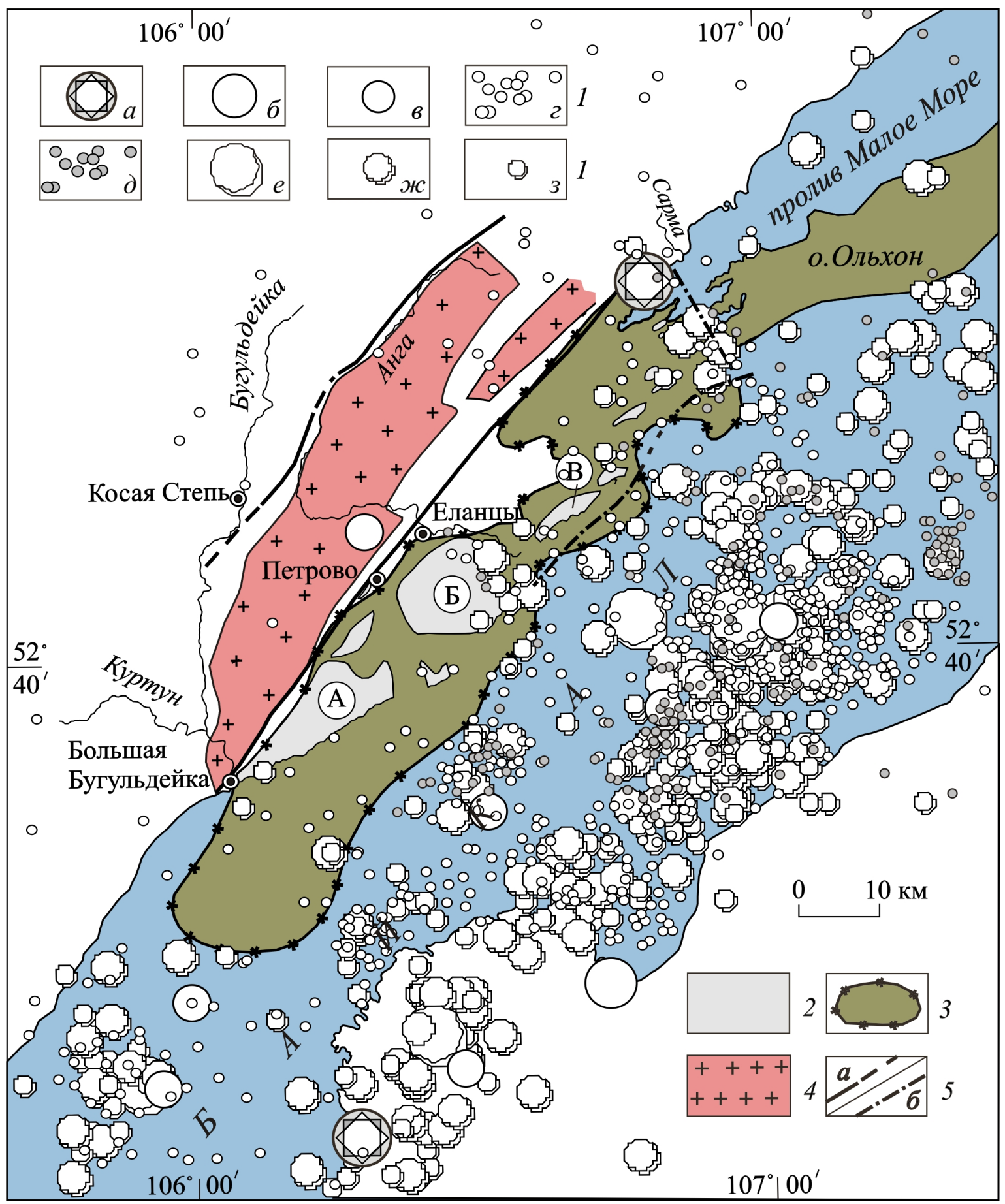

Рис. 10. Схема расположения эпицентров землетрясений и палеосейсмодислокаций Приольхонья.

1 - эпицентры землетрясений: a - K=16-14 по палеосейсмическим данным. Эпицентры землетрясений, зарегистрированных с 1962 по 1976 г.: б - K=17, в - K=16-14, г - K=13-8. Эпицентры землетрясений, зарегистрированных с 1994 по 2011 г.: д - K=13-8. Эпицентры землетрясений, зарегистрированных с 1962 по 1999 г.: е - K=13-10.5, ж - K=10.5-7.5, з - K=7.5-6.5; 2 - выходы на поверхность: А - Бугульдейского (Крестовского), Б - Бирхинского (Озёрского), В - Тажеранского (Улан-Нурского) и других массивов базитового состава; 3 - площадь проекции геологических тел базитового состава (по гравиметрическим данным) на земную и водную поверхности (по [Турутанов, 2010, 2012]); 4 - выходы гранитов; 5 - крупные разломы по геолого-геофизическим данным: а - на поверхности Земли, б - под водой.

Fig. 10. Locations of earthquake epicentres and paleoseismodislocations of the Priolkhonie, Irkutsk region, Russia.

1 - earthquake epicentres: a $-\mathrm{K}=16-14$ according to paleoseismic data. Earthquake epicentres recorded from 1962 to 1976: 6 - K=17, в $-\mathrm{K}=16-$ 14, г - K=13-8. Earthquake epicentres recorded from 1994 to 2011: д - K=13-8. Earthquake epicentres recorded from 1962 to 1999: e - K=1310.5, ж - K=10.5-7.5, з - K=7.5-6.5; 2 - outcrops: A - Bugeldeika (Krestovsky), Б - Birkha (Ozersky), B - Tazheran (Ulan Nursky) and other massifs of basic rocks; 3 - square projections of geological bodies composed of basic rocks (according to gravimetric data) to the ground and water surfaces, according to [Турутанов, 2010, 2012]); 4 - granite outcrops; 5 - large faults according to geological and geophysical data: a - at surface faults, $\sigma$ - underwater faults. 
это можно объяснить увеличением прочностных свойств коры при внедрении высокотемпературных магм основного состава.

\section{3. ИССЛЕДОВАНИЯ ТЕПЛОВОГО ПОЛЯ ЗЕМНОЙ КОРЫ БАЙКАЛЬСКОЙ РИФТОВОЙ ЗОНЫ И ЕГО СВЯЗЬ С ГЛУБИНАМИ ОЧАГОВ ЗЕМЛЕТРЯСЕНИЙ}

Проведено сопоставление глубин гипоцентров с геотермическими данными для трех районов БРЗ, два из которых являются участками Байкальской впадины, третий находится к северо-востоку от нее в пределах Северо-Муйского хребта. Установлено, что глубины гипоцентров землетрясений в сравниваемых районах можно считать одинаковыми, так как они находятся в узких пределах - 2.0-21.2 км. Наблюдаемая в других частях Земли устойчивая взаимосвязь глубин землетрясений и теплового состояния глубинных недр позволяет надеяться, что и в сравниваемых районах БРЗ температура на глубинах 2.0-21.2 км должна быть одинаковой. Сделан вывод о несостоятельности геотермических моделей БРЗ, построенных путем экстраполяции на глубину близповерхностных (измеренных) значений теплового потока, не учитывающих перераспределение тепла подземными водами. Согласно ранее разработанным геотермическим моделям, крупная позднекайнозойская неглубокозалегающая базальтовая интрузия предполагалась и под Байкальской впадиной в районе дельты р. Селенга. Для проверки этой гипотезы было выполнено сопоставление тепловых и сейсмических данных по этому району. Результат использования двух сравниваемых геофизических полей доказал отсутствие этой гипотетической остывающей интрузии.

Результаты сопоставления геотермического и сейсмического полей БРЗ свидетельствуют, что кондуктивное тепловое поле верхней половины земной коры здесь, по-видимому, сильно искажено тепломассопереносом подземными водами. Это указывает на несостоятельность ранних геотермических моделей БРЗ, построенных путем экстраполяции на глубину измеренных близповерхностных величин теплового потока, содержащих эти искажения.

Кроме этого, в рамках «геотермального» направления завершены исследования термальной эволюции и современной геотермальной активности литосферы Центральной и Юго-Восточной Азии, по материалам которых составлены карты теплового потока и современной геотермальной активности литосферы [Лысак, 2009]. Показано, что разновозрастные геологические структуры изученной территории характеризуются различными этапами термальной эволюции и современной геотермальной активностью. Величины теплового потока варьируются от 25 до $150 \mathrm{MBT} / \mathrm{M}^{2}$ и более со средним значением $58 \pm 11 \mathrm{MBT} / \mathrm{m}^{2}$. Его аномально повышенные величины характерны для рифтовых зон, областей динамического влияния активных разломов, а также других структур растяжения, реже сжатия, земной коры. В западных и центральных районах Юго-Восточной Азии аномальные величины тепловых потоков наиболее вероятно связаны с вертикально поднимающимися литосферными и мантийными диапирами. Вариации геотермальной активности контролируются в основном «вращением» Ордосского блока, а также разрывами, подвижки по которым связаны с взаимодействием Индостанской и Евразийской литосферных плит. Показано, что интенсивность современной геотермальной активности в восточных районах Юго-Восточной Азии вызвана субдукцией Тихоокеанской плиты.

\section{4. РАЗРАБОТКА НОВЫХ ТЕХНОЛОГИЙ ПОИСКА МЕСТОРОЖДЕНИЙ ПОЛЕЗНЫХ ИСКОПАЕМЫХ}

Разрабатываемая в последние годы в лаборатории комплексной геофизики технология метода электромагнитного зондирования и вызванной поляризации (ЭМЗВП) предназначена для решения широкого круга задач малоглубинной рудной и нефтяной геофизики, таких, которые традиционными геофизическими методами в настоящее время решить почти невозможно [Агеенков и др., 2012; Давыденко и др., 2013]. Экспериментальный образец аппаратно-программного электроразведочного комплекса «Марс» (АПЭК «Марс») прошел успешную апробацию в Якутии, Приольхонье, и Монголии. Во время полевых испытаний в Якутии по восстановленным из первичных данных переходным процессам рядом с выходящей на дневную поверхность эталонной трубкой взрыва (объект 1) была обнаружена под мерзлыми озерными отложениями заверенная бурением трубка (объект 2), не выделявшаяся ранее (рис. 11). Технология ЭМЗВП и программное обеспечение для АПЭК «Марс» защищены патентом и двумя авторскими свидетельствами, полученными за последние два года.

Метод ЭМЗВП может быть использован в поиске и разведке кимберлитовых алмазоносных трубок, перекрытых излившимися базальтами (траппами), для выделения рудных тел (золото, платина, полиметаллы) в высокоомных средах, а также исследования криолитозоны в решении инженерных задач, в том числе изысканиях при строительстве трубопроводов применительно к условиям Крайнего Севера. Кроме этого, метод может быть востребован в поисках залежей углеводородов, комплексно с технологиями ЭМЗВП с 3D сейсморазведкой.

Перспективы развития исследований в лаборатории комплексной геофизики связываются с использованием записей сейсмических волн на цифровых сейсмических станциях в комплексе с данными гравиметрии и геотермии с целью построения моделей глубинного строения литосферы и астеносферы центральной части Азии для выяснения механизма тектонических (в том числе сейсмогенерирующих) движений. 


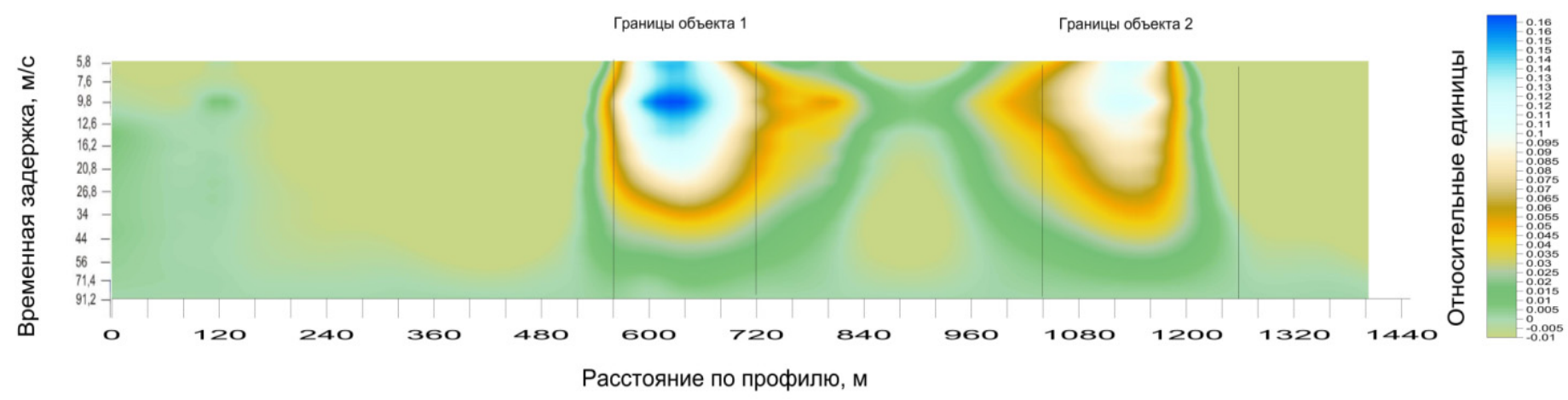

Рис. 11. Псевдоразрезы по электромагнитным данным вдоль линии, проходящей через две трубки взрыва.

Fig. 11. Pseudo-profiles according to electromagnetic data along the line (crossing two breccia pipes).

Для получения практических рекомендаций по выделению потенциально опасных в сейсмическом отношении зон и решения задач сейсмического районирования планируется дополнить традиционные методы изучения сейсмичности и напряженно-деформированного состояния земной коры сейсмоактивных территорий гравиметрическими данными. Изучение соотношения кондукции и конвекции в передаче тепла из глубоких недр Земли к ее поверхности внесет существенный вклад в определение термического режима литосферы и оценку роли глубинного тепла в тектонической активности конкретных регионов. Предполагается продолжить разработку новых перспективных электроразведочных методов поиска и разведки месторождений полезных ископаемых.

\section{3. ПАЛЕОГЕОДИНАМИКА СИБИРИ И ЦЕНТРАЛЬНОЙ АЗИИ (ЛАБОРАТОРИЯ ПАЛЕОГЕОДИНАМИКИ)}

Свое современное название лаборатория палеогеодинамики получила 1986 г., после того как в единое научное подразделение были объединены две уже существовавшие в институте лаборатории: лаборатория тектоники (зав. лабораторией С.М. Замараев, 19681984 гг., В.Г. Беличенко, 1984-1986 гг.) и лаборатория геологии и металлогении докембрия (зав. лабораторией А.П. Шмотов, 1971-1986 гг.). Однако истоки лаборатории палеогеодинамики прослеживаются более чем на 60 лет в глубь истории института: сначала (1962 г.) в лабораторию тектоники и структурной геологии (зав. лабораторией Н.А. Флоренсов), далее (1955-1961 гг.) - в отдел региональной геологии (рук. Н.А. Флоренсов) и практически к моменту основания института (1951 г.), когда в его структуре был создан отдел общей геологии и полезных ископаемых (рук. Е.В. Павловский).

К наиболее значимым достижениям лаборатории во второй половине ХХ в. можно отнести обоснование рудной специфики обширных территорий Прибайка- лья, разработку методики геологического картирования древних метаморфических толщ, составление серии литолого-палеогеографических карт и карт метаморфизма для территории Сибирской платформы и Центрально-Азиатского складчатого пояса (ЦАСП), открытие крупноамплитудных надвигов на юге Сибирского кратона, разработку модели террейновой структуры Забайкалья, обнаружение на площади Сибирского кратона фрагментов древней (2.0 млрд лет) океанической коры (офиолитов и эклогитов), выявление в структуре забайкальского сегмента ЦАСП комплексов метаморфических ядер (КМЯ) и многое другое. Результаты этих исследований вошли в такие фундаментальные научные издания, как «Стратиграфия СССР» (1963г.), «Геология СССР» (1961-1964 гг.), восьмитомная монография «Геология и сейсмичность зоны БАМ» (1983-1985 гг.), «Комплексы метаморфических ядер кордильерского типа» (1997 г.) и др.

В начале XXI в. при определяющей роли сотрудников лаборатории в рамках Федеральной целевой программы «Интеграция науки и высшей школы» была подготовлена и опубликована целая серия учебных пособий для вузов, включающая следующие издания: «Интерпретация геохимических данных», «Метаморфизм и тектоника», «Минералогия Восточной Сибири на пороге XXI века», «Методы структурного анализа полиметаморфических комплексов», «Геодинамические режимы формирования Центрально-Азиатского складчатого пояса». Один из этих учебников («Интерпретация геохимических данных») в последующем был переведен и издан в Монголии.

В настоящее время (начало 2014 г.) в лаборатории работает 26 человек, в том числе 1 член-корреспондент РАН, 7 докторов и 6 кандидатов наук (рис. 12).

Основные научные направления исследований лаборатории:

- процессы формирования континентальной литосферы Центральной Азии и их геодинамический контроль; 


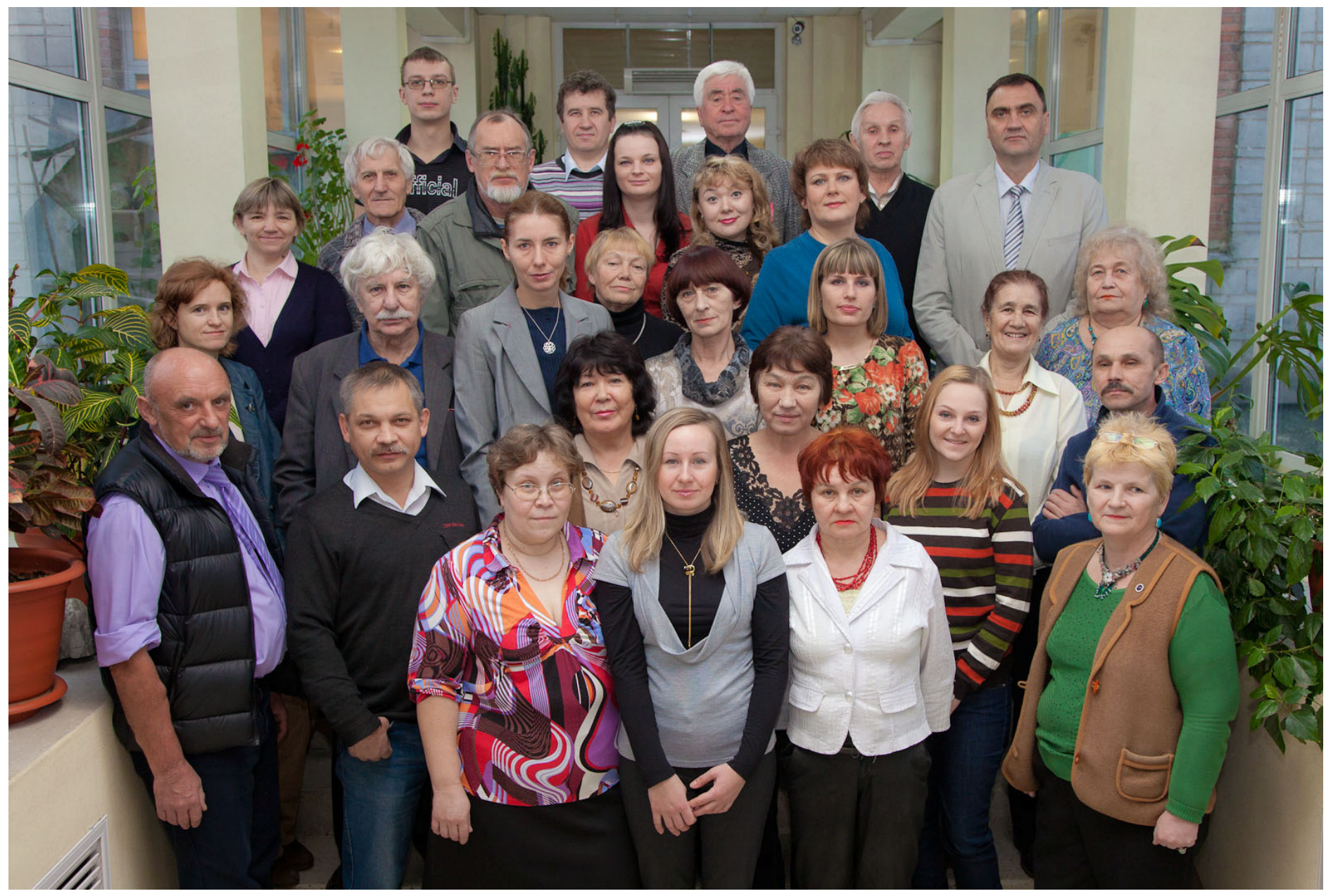

Рис. 12. Сотрудники лаборатории палеогеодинамики.

Первый ряд (слева направо): чл.-корр. РАН Е.В. Скляров, И.Г. Бараш, Т.В. Ляхова, Р.М. Ивченко, Е.Е. Бадашкова, Э.В. Бидаева, В.П. Киямова, А.В. Щербак, Т.А. Корнилова; второй ряд: к.г.-м.н. Е.И. Демонтерова, к.г.-м.н. Л.З. Резницкий, к.г.-м.н. Т.В. Донская, Н.А. Садовникова, к.г.-м.н. Н.К. Гелетий, Е.Н. Федерягина, Л.В. Фивейская, В.И. Конорев; третий ряд: к.г.-м.н. С.И. Школьник, д.г.-м.н. А.М. Мазукабзов д.г.-м.н. А.М. Станевич, З.Л. Мотова, к.г.-м.н. С.А. Анисимова, А.В. Коптева, д.г.-м.н. Д.П. Гладкочуб - зав. лабораторией, Е.А. Некрасова, четвертый ряд: И.К. Константинов, д.г.-м.н. А.В. Иванов, д.г.-м.н. В.К.Лапердин, В.П. Юрков.

Fig. 12. The staff of the Laboratory of Paleogeodynamics.

$1^{\text {st }}$ row - E.V. Sklyarov, I.G. Barash, T.V. Lyakhova, R.M. Ivchenko, E.E. Badashkova, E.V. Bidaeva, V.P. Kiyamova, A.V. Shcherbak, T.A. Kornilova; $2^{\text {nd }}$ row - E.I. Demonterova, L.Z. Reznitsky, T.V. Donskaya, N.A. Sadovnikova, N.K. Gelety, E.N. Federyagina, L.V. Fiveiskaya, V.I. Konorev; $3^{\text {rd }}$ row - S.I. Shkol'nik, A.M. Mazukabzov, A.M. Stanevich, Z.L. Motova, S.A. Anisimova, A.V. Kopteva, D.P. Gladkochub (Head of the Laboratory), E.A. Nekrasova; $4^{\text {th }}$ row - I.K. Konstantinov, A.V. Ivanov, V.K. Laperdin, V.P. Yurkov.

- становление структуры Сибирского кратона и Центрально-Азиатского складчатого пояса;

- геодинамика области сочленения Сибирского кратона и Центрально-Азиатского складчатого пояса;

- новые минералы и их роль в реконструкции геодинамических режимов.

Сотрудники лаборатории, для выполнения исследований используют целый комплекс современных методов анализа минералов и горных пород, выполняя аналитические измерения как в Иркутске - на базе Байкальского аналитического ЦКП ИНЦ СО РАН, так и за рубежом - в Германии, Австралии, США, Китае и других странах.
В лаборатории успешно эксплуатируется многоканальный газовый масс-спектрометр ARGUS VI. Этот специализированный прибор нового поколения используется для исследований изотопного состава аргона (природных - ${ }^{40} \mathrm{Ar},{ }^{38} \mathrm{Ar},{ }^{36} \mathrm{Ar}$ и образуемых при облучении образца быстрыми нейтронами в ядерном реакторе - ${ }^{39} \mathrm{Ar},{ }^{37} \mathrm{Ar}$ ). Масс-спектрометр может использоваться для изучения более легких газов, например изотопов азота, и определения концентраций гелия-4. В эксплуатации прибор находится с мая 2012 г., и к настоящему времени на нем $\mathrm{Ar} / \mathrm{Ar}$ методом было датировано более 100 геологических образцов, включая природные стандарты. 


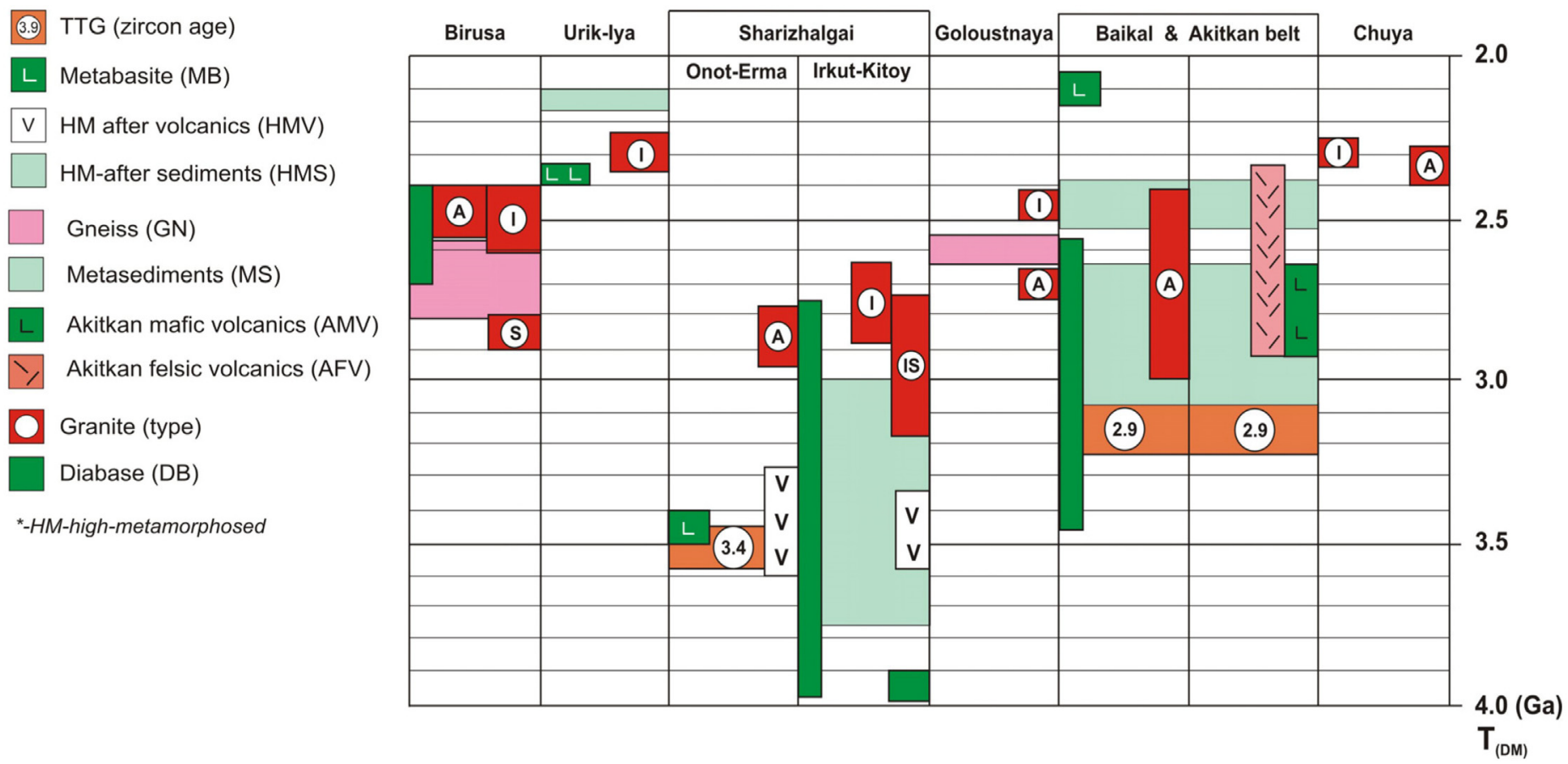

Рис. 13. Схема проявления корообразующих процессов в пределах основных структур южного фланга Сибирского кратона [Gladkochub et al., 2009].

Fig. 13. The scheme of the crust formation within the limits of the main structures comprising the southern flank of the Siberian craton [Gladkochub et al., 2009].

Основные научные достижения лаборатории за 2009-2013 гг. (по направлениям):

\section{1. ПРОЦЕССЫ ФОРМИРОВАНИЯ КОНТИНЕНТАЛЬНОЙ ЛИТОСФЕРЫ ЦЕНТРАЛЬНОЙ АЗИИ И ИХ ГЕОДИНАМИЧЕСКИЙ КОНТРОЛЬ}

3.1.1. Проведены исследования изотопных систем $\mathrm{Nd}$ в интрузивных и метаморфических породах, слагающих основные террейны южной части Сибирского кратона. На основе полученных материалов сделан вывод об изотопной гетерогенности изученной территории и выделены основные рубежи проявления корообразующих процессов. Сделано предположение о том, что ранние (палео- и мезоархейские) уровни корообразующих процессов отражают стадию становления протоконтинентальных платформ (фрагментов протосиаля) (рис. 13), на которых в последующем накапливались неоархейские вулканогенно-осадочные и осадочные образования.

Таким образом, структура южной части кратона может быть охарактеризована как мозаика отдельных террейнов с архейским основанием, каждый из которых имеет собственную уникальную историю становления и раннего развития.

Объединение этих разрозненных террейнов в единую общую структуру кратона произошло в палеопро- терозое (2.0-1.9 млрд лет), о чем свидетельствуют реликты палеопротерозойской ювенильной коры, обнаруженные в изученном регионе [Gladkochub et al., 2009].

3.1.2. Впервые доказано присутствие архейских пород в пределах Акитканского складчатого пояса Сибирского кратона, разделяющего Алданский и Анабарский супертеррейны. Ранее считалось, что породы Акитканского складчатого пояса были сформированы исключительно на палеопротерозойском ювенильном основании. Мезоархейские разгнейсованные гранитоиды были изучены в пределах Байкальского выступа фундамента кратона (район мыса Хибелен). Исследованные гранитоиды представлены и гранитами. U-Pb датирование по циркону тоналитов показало, что они

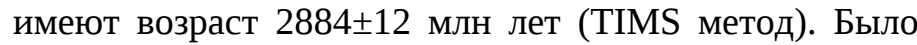
предложено два возможных варианта эволюции Акитканского складчатого пояса до коллизии Анабарского и Алданского супертеррейнов. Согласно первому варианту, Анабарский супертеррейн на временном рубеже 2.0-2.1 млрд лет мог развиваться в режиме активной континентальной окраины, палеопротерозойские комплексы могли формироваться вдоль активной окраины, а мезоархейские гранитоиды в этом случае могли являться частью Анабарского супертеррейна. Согласно второму варианту, палеопротерозойские и архейские комплексы пород, выделяющиеся в Акит- 


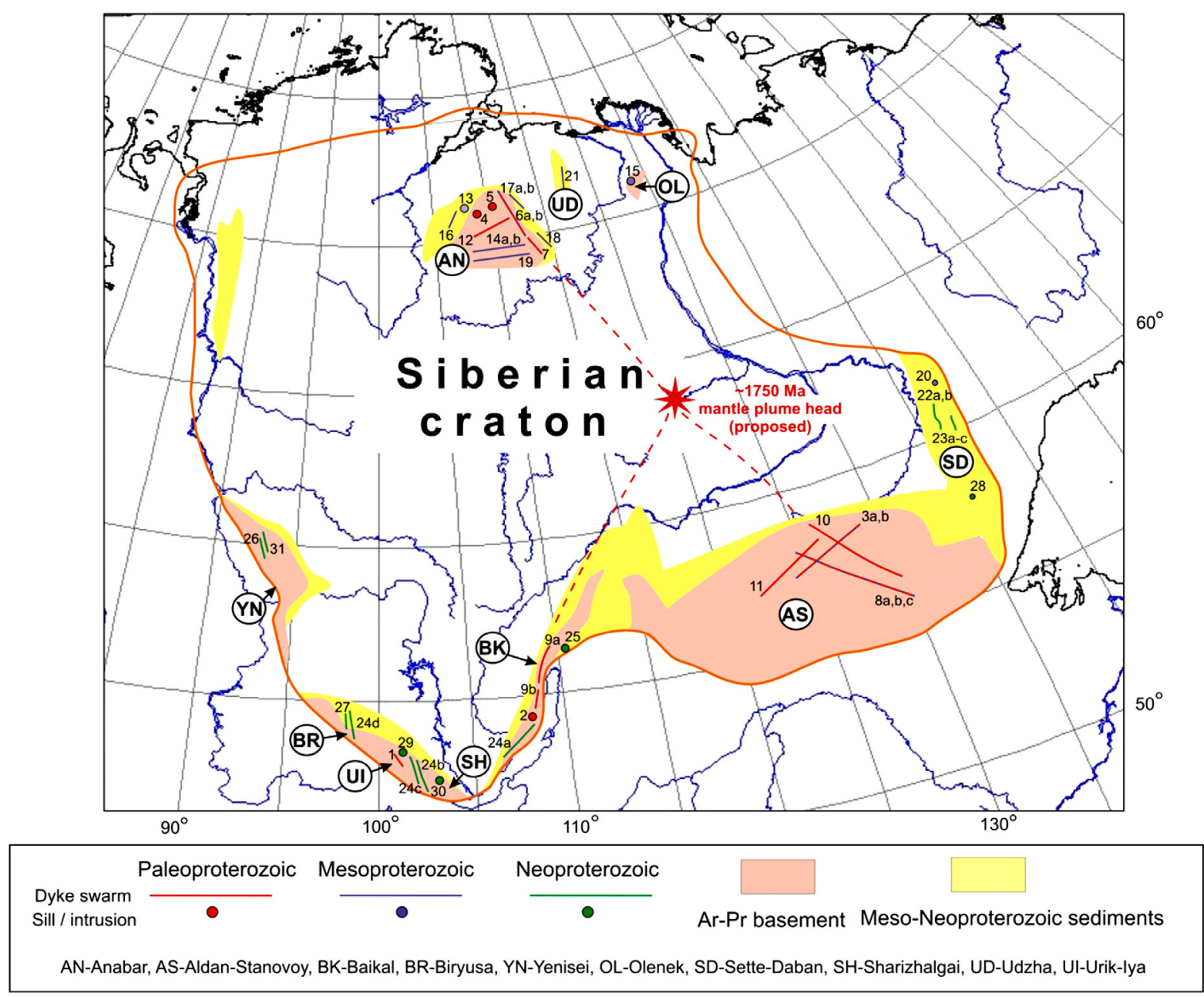

Рис. 14. Карта размещения базитовых интрузий на площади Сибирского кратона [Gladkochub et al., 2010].

Fig. 14. The map of basic rock intrusions in the territory of the Siberian craton [Gladkochub et al., 2010].

канском складчатом поясе, до момента объединения Анабарского и Алданского супертеррейнов имели полностью автономное развитие и были вовлечены в единую структуру только в результате коллизии. Коллизия Анабарского и Алданского супертеррейнов произошла на временном рубеже $\sim 1.9$ млрд лет. Завершающей стадией этой коллизии явилось формирование постколлизионных образований с возрастом 1.87-1.84 млрд лет, широко представленных в структуре Акитканского складчатого пояса [Donskaya et al., 2009].

3.1.3. Создана карта докембрийского базитового магматизма Сибирского кратона (рис. 14) [Gladkochub et al., 2010]. В ходе работы над картой были получены следующие основные результаты:

1. Установлено, что в истории протерозойского базитового магматизма Сибири могут быть выделены три основных импульса (рис. 14), отвечающие позднему палеопротерозою, раннему мезопротерозою и неопротерозою.
2. Проявленный повсеместно на площади Сибирского кратона палеопротерозойский базитовый магматизм с возрастом около 1850 млн лет был обусловлен процессами постколлизионного растяжения, сменившего коллизионно-аккреционную стадию, ответственную за объединение разрозненных террейнов и супертеррейнов в единую структуру кратона.

3. Новые геохронологические данные, полученные для базитовых дайковых роев Байкальского выступа, Алдано-Станового и Анабарского щитов, позволили обосновать присутствие на площади Сибирского кратона крупной магматической провинции (КМП), возраст которой близок к 1750 млн лет [Гладкочуб и др., 2010].

4. Мезопротерозойский базитовый магматизм, проявленный на севере кратона (Анабарский щит $1384 \pm 2$ млн лет, Оленекский выступ - $1473 \pm 24$ млн лет), по-видимому, был обусловлен широким развитием процессов внутриплитного растяжения, наиболее ярким проявлением (результатом) которых стало 
D.P. Gladkochub, E.Kh. Turutanov: The deep structure and paleogeodynamics of Siberia and Central Asia...

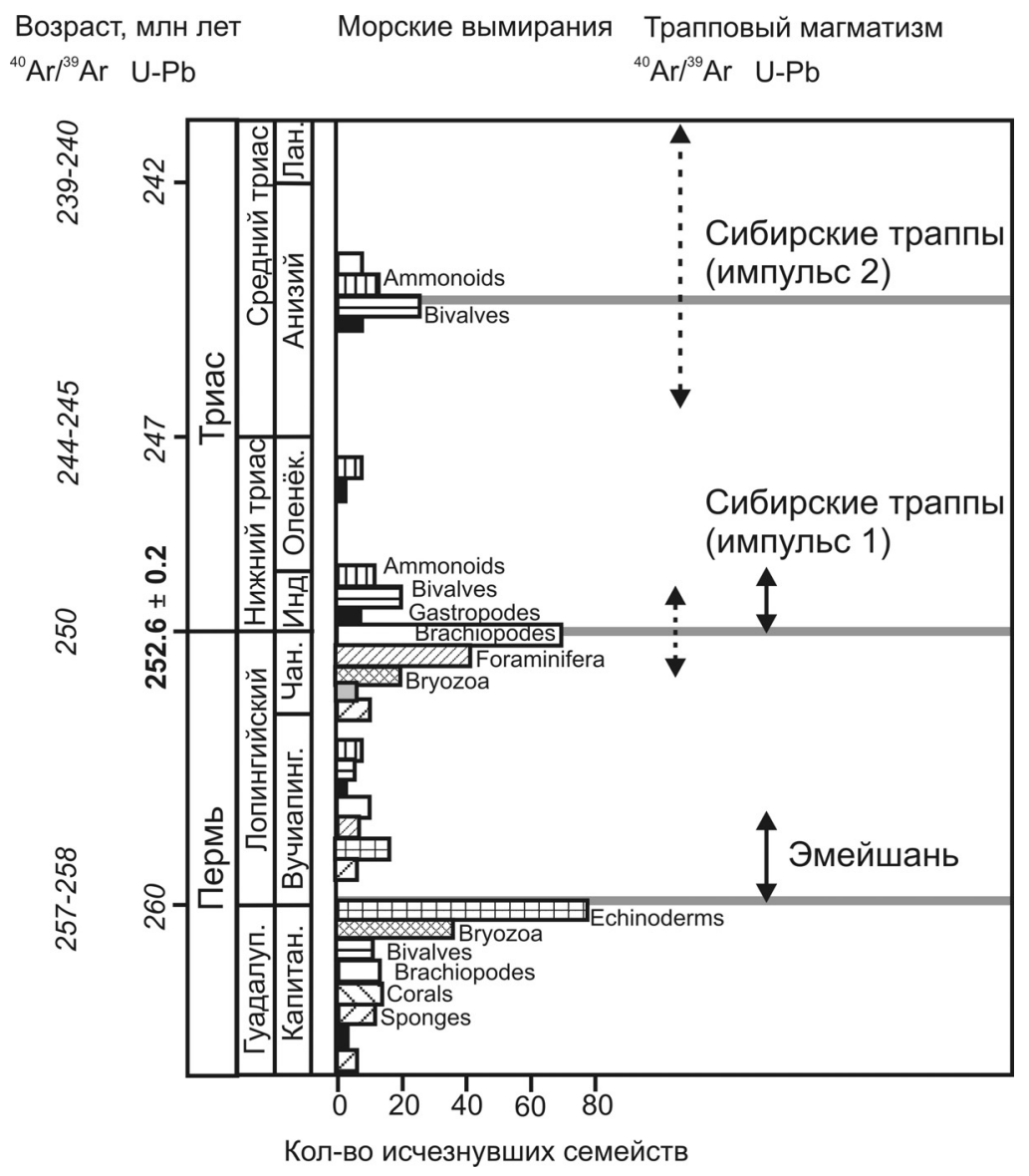

Рис. 15. Сопоставление времени вымирания морских организмов (горизонтальные серые полосы) с временем траппового магматизма в провинциях Эмейшань и Сибирских траппов.

Жирными и пунктирными вертикальными стрелками показаны интервалы базальтового магматизма в пределах этих провинций, установленные по данным U-Pb и ${ }^{40} \mathrm{Ar} /{ }^{39} \mathrm{Ar}$ датирования, соответственно. Столбиками показано количество вымерших семейств морских организмов во время каждого из трех событий массового вымирания.

Fig. 15. The marine organisms extinction time (grey horizontal lines) versus the trapp magmatism time in Emeishan Province, China and the Siberian trapps, Russia.

Thick and dotted vertical arrows show basalt magmatism intervals within the limits of the provinces under study, as established from U-Pb and ${ }^{40} \mathrm{Ar} /{ }^{39} \mathrm{Ar}$ datings, respectively. Columns show the number of extinct marine organisms during each of the three events of mass extinction.

заложение и раскрытие Уджинского авлакогена.

5. Присутствие мезопротерозойского базитового магматизма на востоке кратона (Сетте-Дабан) подтверждается единственной надежной датировкой (1339 \pm 54 млн лет), полученной Sm-Nd методом по апатиту, клинопироксену и валу породы, отражая локальный характер проявления базитовых комплексов мезопротерозоя на рассматриваемой территории.

6. Наиболее ранние процессы растяжения в неопротерозое ( 1000 млн лет) проявились на востоке Алданской провинции (Учуро-Майский район), где они фиксируют ранние стадии рифтогенного раскола Родинии.

7. Наиболее масштабно процессы растяжения неопротерозойского времени проявлены на южном фланге кратона дайковыми роями с возрастом 740-800 млн лет. Эти базитовые интрузии являются свидетельствами продвинутой стадии рифтогенеза.
8. Индикаторов предвендского растяжения в Сибири значительно меньше. Эти события фиксируются, в частности, позднерифейскими ультраосновными щелочными породами Белозиминского (642 млн лет), Жидойского (632 млн лет) и Ингилийского (647 млн лет) массивов. Этот рубеж может рассматриваться как верхний возрастной предел рифтогенеза, закончившегося отделением Сибирского кратона от Родинии [Gladkochub et al., 2010].

3.1.4. На основании анализа новых и ранее опубликованных ${ }^{40} \mathrm{Ar} /{ }^{39} \mathrm{Ar}$ датировок, полученных для Провинции Сибирских траппов, показано, что базальты и их интрузивные аналоги внедрялись в результате двух коротких импульсов: в раннем (249-252 млн лет) и среднем (240 млн лет) триасе (рис. 15). Эти же пики характерны для внедрения других типов магм (меймечитов, лампроитов, сиенитов и гранитоидов). 


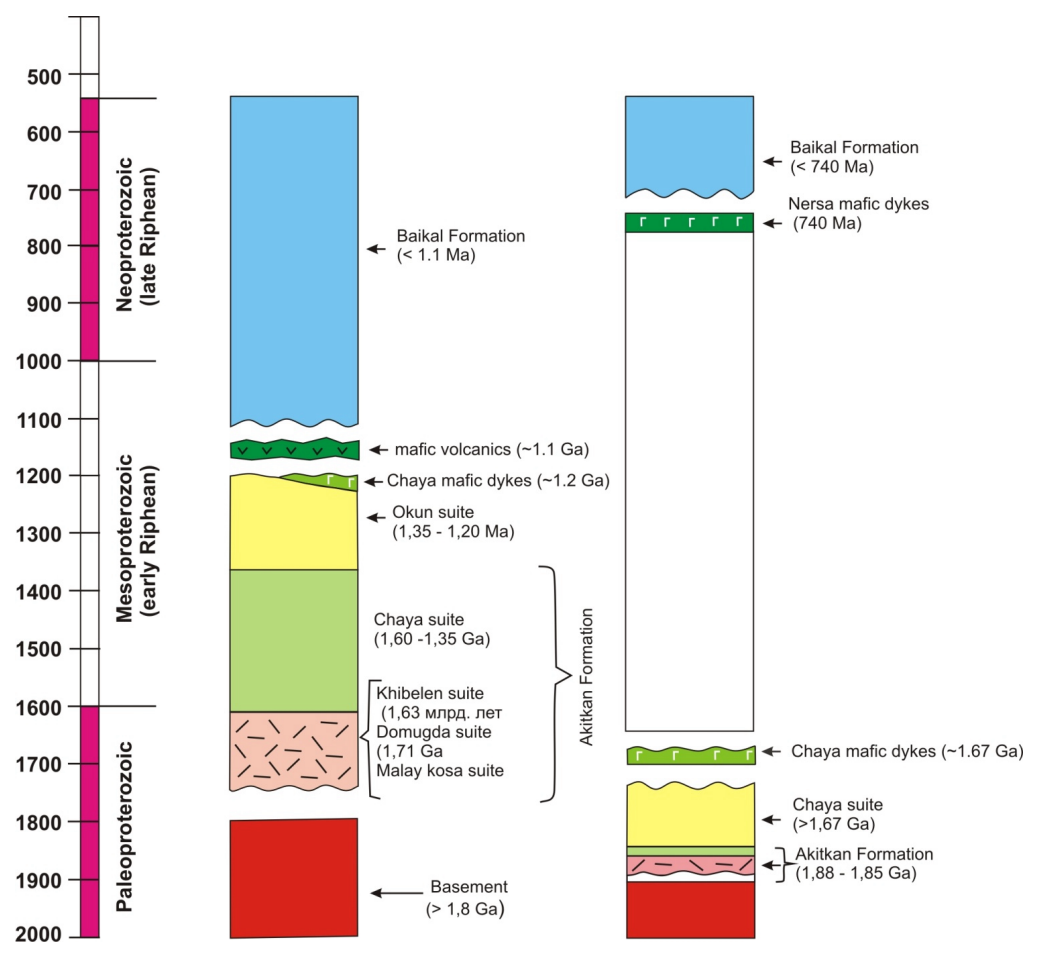

Рис. 16а. Схемы хронологической последовательности геологических событий на площади Прибайкальского поднятия: ранее допускаемая и пересмотренная с учетом новых геохронологических данных.

Fig. 16a. Schemes of the chronological sequence of geological events in the territory of the Pribaikalian uplift (assumed earlier and reviewed with account of new geochronological data).

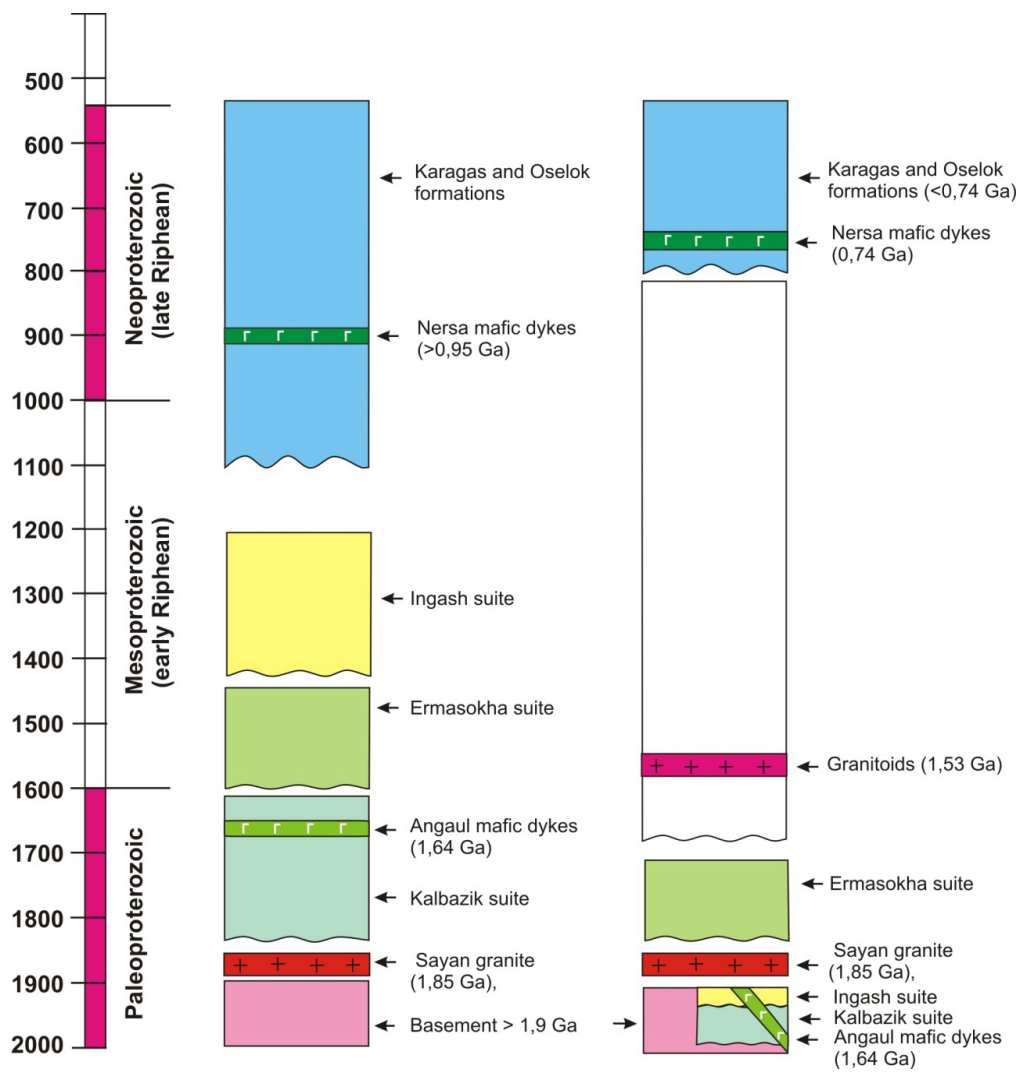

Рис. 16б. Схемы хронологической последовательности геологических событий на площади Присаянского поднятия: ранее допускаемая и пересмотренная с учетом новых геохронологических данных.

Fig. 16б. Schemes of the chronological sequence of geological events in the territory of the Prisayan uplift (assumed earlier and reviewed with account of new geochronological data). 
D.P. Gladkochub, E.Kh. Turutanov: The deep structure and paleogeodynamics of Siberia and Central Asia...
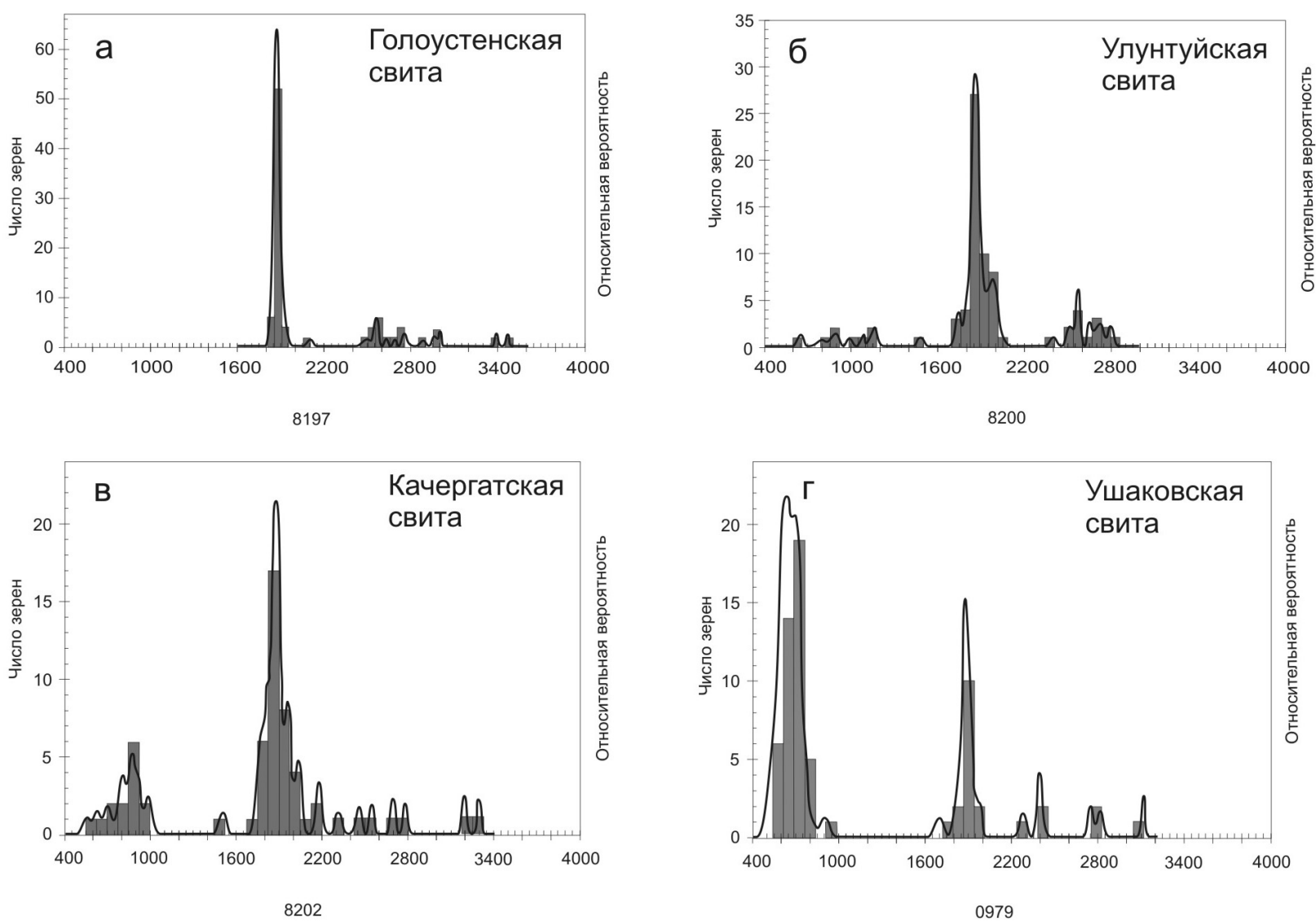

Рис. 17. U-Pb (<1 млрд лет) Pb-Pb (> 1 млрд лет) гистограммы и кривые относительной вероятности возраста детритовых цирконов из неопротерозойских осадочных пород южной части Сибирского кратона.

$a-8$ байкальская серия: $a$ - голоустенская свита, $\sigma$ - улунтуйская свита, 8 - качергатская свита; 2 - ушаковская свита.

Fig. 17. Histograms U-Pb ( $<1$ billion years) and $\mathrm{Pb}-\mathrm{Pb}(>1$ billion years) and curves of relatively probable ages detrital zircones from the Neoproterozoic sedimentary rocks of the southern part of the Siberian craton. The Baikal series.

a - Goloustenskaya suite, б - Uluntuiskaya suite, в - Kachergatskaya suite; г - Ushakovskaya suite.

О том, что это событие занимало продолжительный период времени, было известно и ранее, однако импульсность и совпадение базальтового и кислого магматизма показаны впервые. Показано, что пермотрасовый и среднетриасовый пики траппового (и сопутствовавшего) магматизма хорошо коррелируют с эпохами массовых вымираний, вызванных выбросами в атмосферу ядовитых метаморфогенных газов, образующихся при взаимодействии пластовых интрузий тел (силлов) с осадочными породами, богатыми органическими останками, нафтидами и солями. Сопоставление прецизионных результатов изотопного датирования траппов с палеонтологическими данными подтверждает эту гипотезу [Ivanov et al., 2013].

\section{2. СТАНОВЛЕНИЕ СТРУКТУРЫ СИБИРСКОГО КРАТОНА И ЦЕН- ТРАЛЬНО-АЗИАТСКОГО СКЛАДЧАТОГО ПОЯСА}

3.2.1. Синтез новых датировок и их применение для определения возрастных ограничений докембрийских осадочных толщ Прибайкалья позволили выявить для региона глобальный по своей продолжительности перерыв (между 1.7 и 0.8 млрд лет) в эндогенной активности, а также отсутствие осадочных комплексов, отвечающих данному периоду геологической истории. На площади Присаянского поднятия аналогичный перерыв охватывает интервал времени около 1.1 млрд лет (между 1.85 и 0.75 млрд лет) (рис. 16а), а перерыв в осадконакоплении в отдельных разрезах (Бирюсинский и Шарыжалгайский блоки) даже превосходит эту оценку (рис. 16б).

Выявленный феномен позволил обосновать необходимость коренного переосмысления сценария развития южной части Сибирского кратона в докембрии, а также акцентировать внимание на глобальном по своим масштабам перерыве в эндогенной активности и осадочных разрезах юга Сибирского кратона. Этот перерыв охватывает практически весь объем рифея.

Амагматичность, отсутствие свидетельств метаморфического преобразования пород и их вовлеченно- 


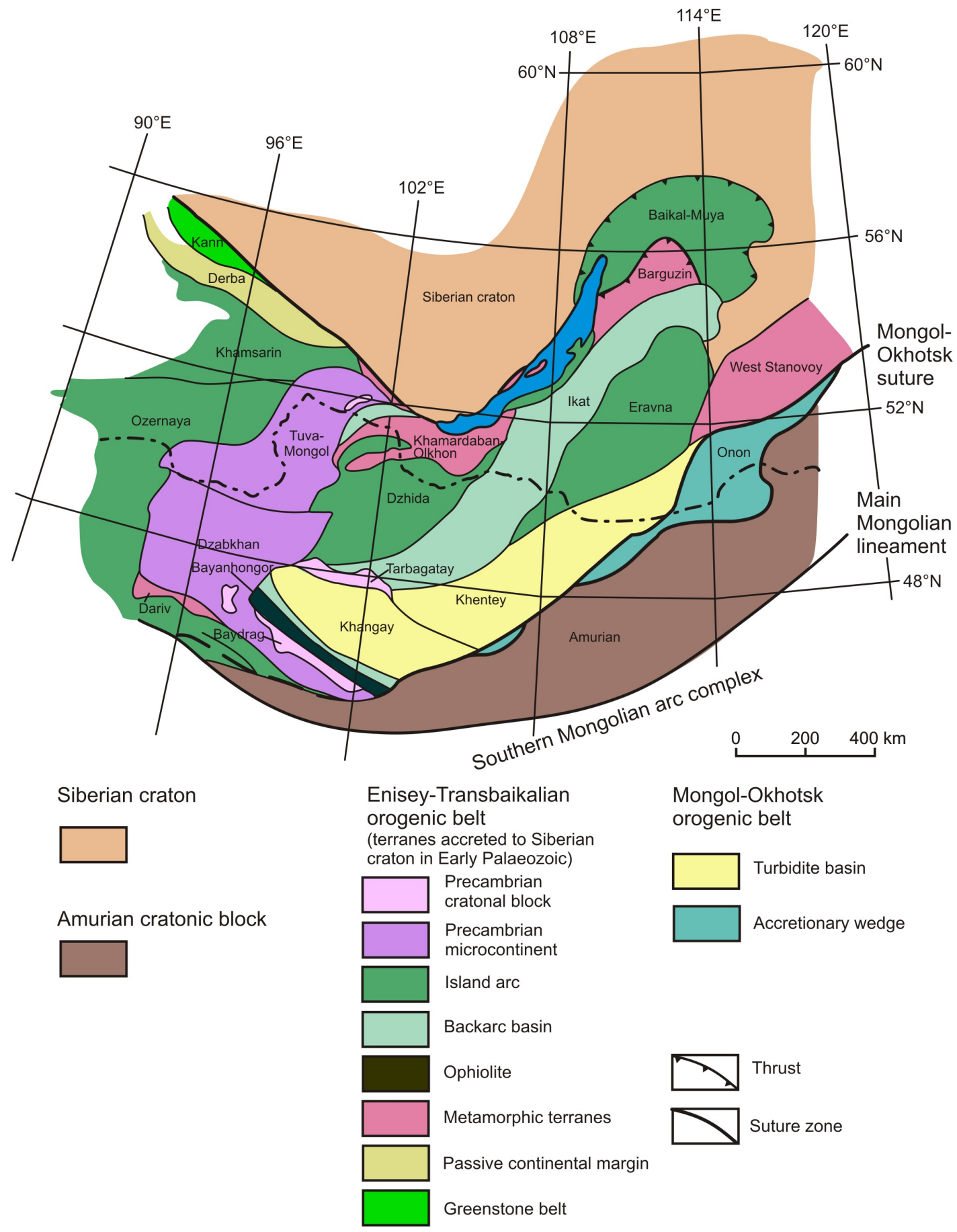

| Рис. 18. Карта террейнов северного сегмента Центрально-Азиатского складчатого пояса (по [Gladkochub et al., 2013]).

I Fig. 18. The map of terrains of the northern segment of the Central Asian folded belt according to [Gladkochub et al., 2013].

сти в какие-либо тектонические процессы на протяжении длительного ( 1.70-0.70 млрд лет) периода истории могут быть обусловлены нахождением южной части Сибирского кратона во внутренних областях коллажа нескольких древних кратонов (суперконтинента). Таким образом, полученные для юга Сибири данные могут свидетельствовать в пользу возможности существования на Земле транспротерозойского суперконтинента, т.е. фрагмента Нуны (Колумбии) (объединявшего Сибирь, Лаврентию и Гренландию), трансформировавшегося в Родинию и распавшегося в позднем неопротерозое.

Практически полное отсутствие рифейских (доэдиакарских) осадочных толщ на юге Сибирского кратона может быть объяснено сносом обломочного материала с площади Присаянского и Прибайкальского поднятий на прилегающие шельфы, которые в последующем, на стадии распада Родинии и раскрытия 


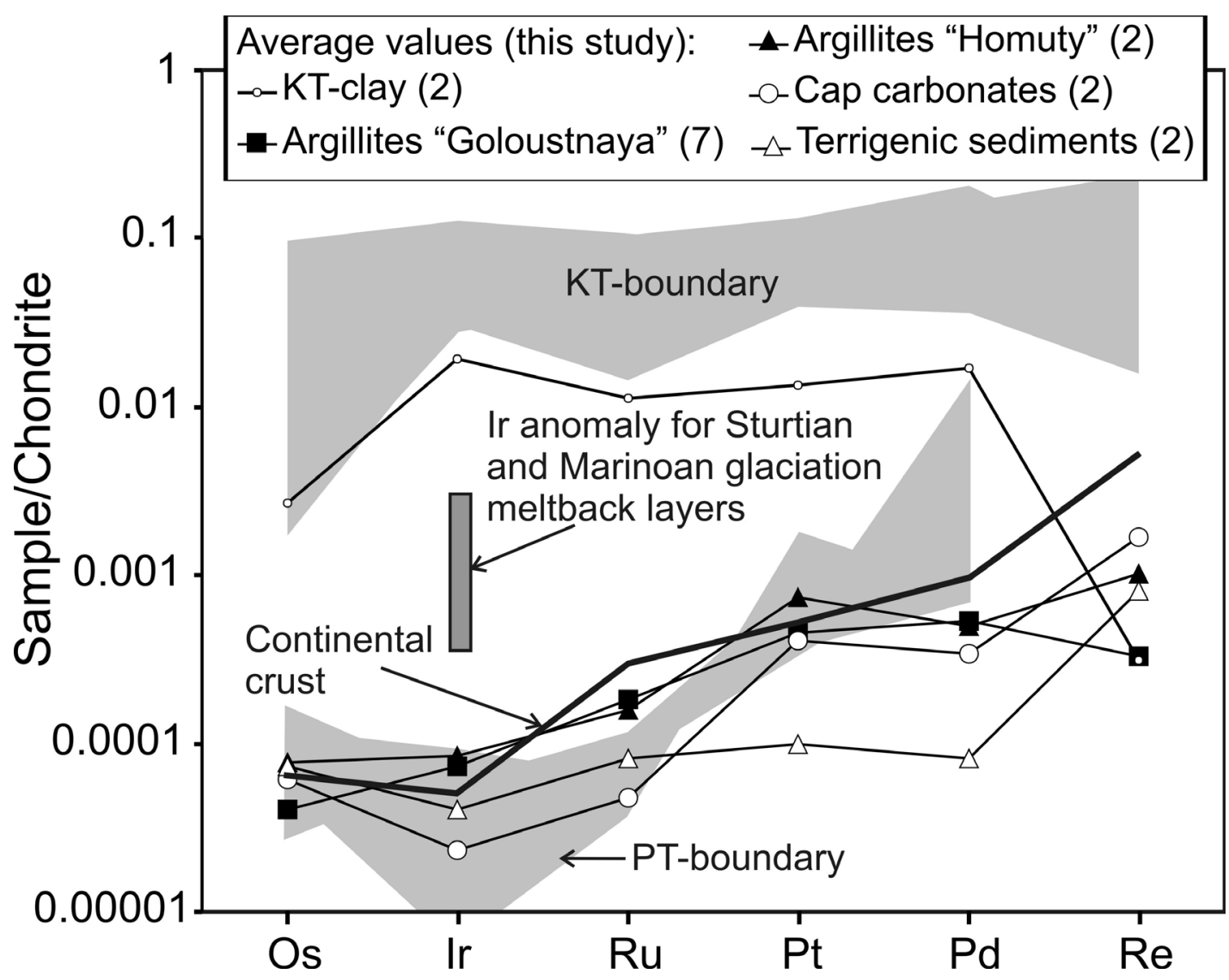

Рис. 19. Вариации нормированных к хондриту концентраций элементов платиновой группы и рения в матриксе ледниковых отложений оледенения Гаскье и постледниковых аргиллитах и карбонатах в сравнении с данными по осадкам пермотриасовой и мел-палеогеновой границ.

Приведен также диапазон нормированных концентраций Ir для постледниковых аргиллитов оледенений Стёрт и Мариноа, для которых предполагается режим «снежка». Цифрами в скобках указано число образцов, использованных для осреднения.

Fig. 19. Variations of chondrite-rated concentrations of platinum group elements and rhenium in the matrix of glacial deposits of Gasquier glaciation and post-glaciation argillites and carbonates in comparison with data on sediments at the Perm-Triassic and Cretaceous-Paleogenic boundaries.

See also the range of rated concentrations of Ir for post-glaciation argillites of Sturt and Marinoan glacial deposits with the assumed 'snow flurry' regime. Numbers in brackets show the number of samples referred to for averaging.

Палеоазиатского океана, оказались отчлененными от кратона и в настоящее время не могут быть надежно идентифицированы [Gladkochub et al., 2010].

3.2.2. С целью изучения условий седиментогенеза на южной окраине Сибирского кратона, протекавшего на фоне распада Родинии, раскрытия и начальных стадий развития Палеоазиатского океана, были исследованы отложения байкальской и слюдянской серий позднего докембрия Прибайкалья. В рамках работ выполнено изучение U-Pb возраста (LA-ICP-MS) детритовых цирконов из терригенных пород байкальской серии и ушаковской свиты Западного Прибайкалья (рис. 17) и дана интерпретация источников обломочного материала для изученных осадочных толщ. Установлено, что возраст наиболее молодой группы детритовых цирконов, выделенных из отложений верхней части байкальской серии и ушаковской свиты, позво- ляет ограничить время седиментации этих толщ вендом. Выявлено отсутствие в большей части проанализированных проб детритовых цирконов мезопротерозойского возраста, что подтверждает гипотезу о существовании глобального по своей продолжительности (около 1 млрд лет) перерыва в эндогенной активности, проявившегося в пределах южного фланга Сибирского кратона на протяжении докембрийского этапа его развития. Сделан вывод о том, что обилие неопротерозойских цирконов в песчаниках из верхних горизонтов байкальской серии и ушаковской свиты может быть объяснено сокращением площади океанического бассейна в результате сближения кратона с микроконтинентами и островными дугами (рис. 18), существовавшими в пределах Палеоазиатского океана [Гладкочуб и др., 2013].

Определены концентрации элементов группы пла- 


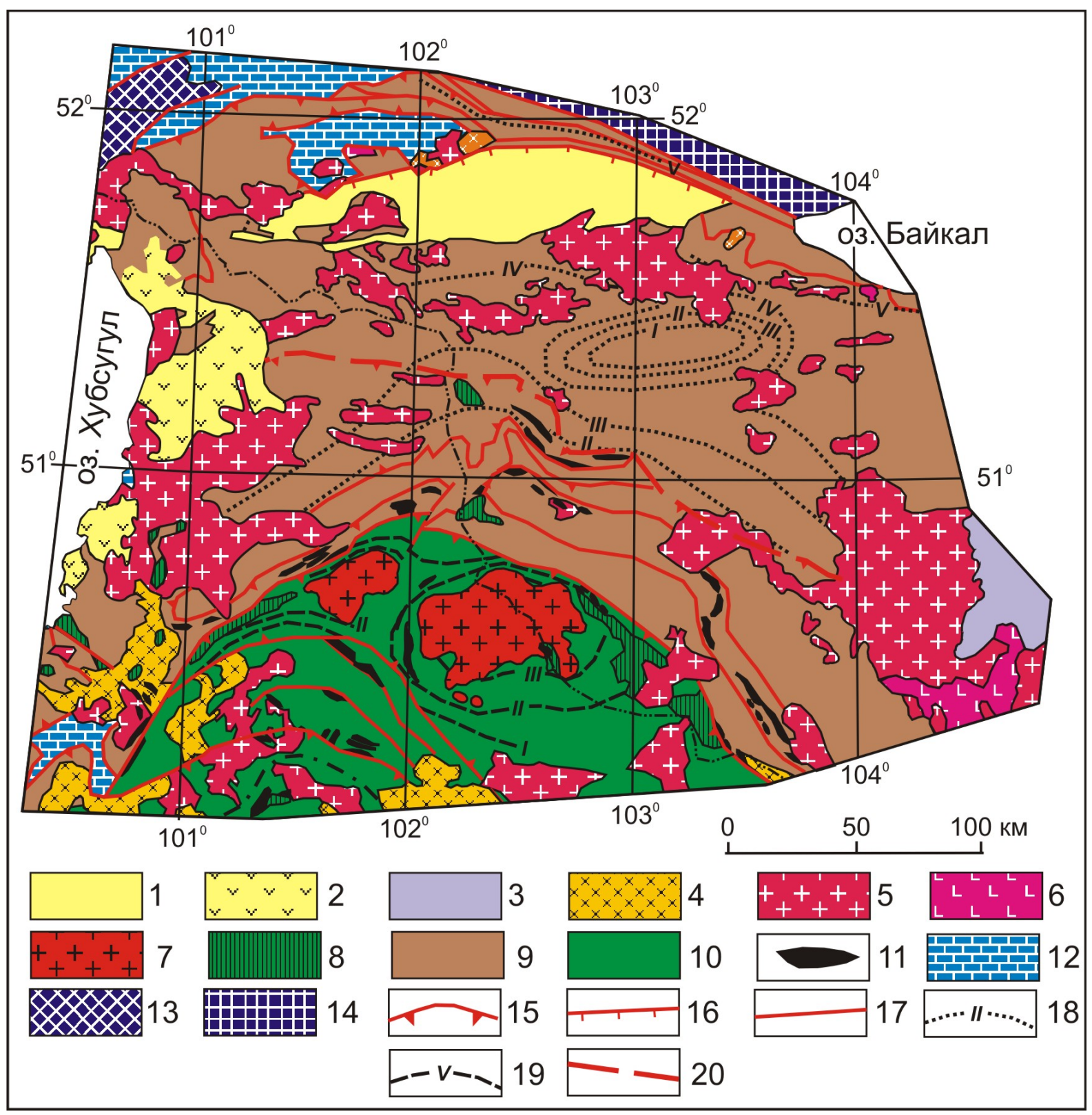

Рис. 20. Геологическое строение Джидинско-Хамардабанского района.

1 - кайнозойские отложения Тункинской рифтовой впадины; 2 - кайнозойские базальты; 3 - мезозойская осадочно-вулканогенная толща; 4 - позднепалеозойские (298 Ма) граносиениты и сиениты; 5 - ордовикские (478-495 Ма) гранитоиды; 6 - ордовикские диориты и габбро; 7 - кембрийские (505-540 Ма) тоналиты и гранодиориты; 8 - кембрийские габбро и диориты; 9 - венд-раннепалеозойские осадочные и осадочно-вулканогенные серии пород окраинного бассейна; 10 - венд-раннепалеозойские вулканогенные и осадочно-вулканогенные серии островной дуги; 11 - гипербазиты (фрагменты расчлененных офиолитов); 12 - венд-раннепалеозойский карбонатный чехол Тувино-Монгольского микроконтинента; 13 - Гарганская глыба (ранний докембрий); 14 - Сибирский кратон; 15 - надвиги; 16 сбросы; 17 - разломы с неустановленной кинематикой; 18 - изограды ордовикского метаморфизма: I - граната, II - ставролита и андалузита, III - силлиманита, IV - силлиманита - калиевого полевого шпата, $V$ - гиперстена; 19 - изограды кембрийского метаморфизма: I - граната, II - ставролита и дистена, III - силлиманита; 20 - предполагавшаяся ранее граница между Джидинской (к югу) и Хамардабанской ( к северу) зонами.

Fig. 20. The geological setting of the Dzhida-Khamardabam region.

1 - Cenozoic deposits of the Tunka rift basin; 2 - Cenozoic basalts; 3 - Mesozoic sedimentary-volcanogenic bed; 4 - Late Paleozoic (298 Ma) granosienites and sienites; 5 - Ordovician (478-495) granitoides; 6 - Ordovician diorites and gabbro; 7 - Cambrian (505-540 Ma) tonalities and granodiorites; 8 - Cambrian gabbro and diorites; 9 - Vend-Early Paleozoic volcanogenic and sedimentary-volcanogenic series of rocks of the marginal basin; 10 - Vend-Early Paleozoic sedimentary and sedimentary-volcanogenic series of the island arc; 11 - ultrabasites (fragments of split ophiolites); 12 - Vend-Early Paleozoic carbonate cover of the Tuva-Mongolian micro-continent; 13 - Gargan rock (Early Precambrian); 14 - Siberian craton; 15 - thrusts; 16 - normal faults; 17 - faults with unidentified kinematics; 18 - isogrades of the Ordovician metamorphism: I - garnet, II - stavrolite and andalusite, III - sillimanite, IV - sillimanite-potassium fieldspar, V - hypersthene; 19 - isogrades of the Cambrian metamorphism: I - garnet, II - stavrolite and distene, III - sillimanite; 20 - earlier assumed boundary between the Dzida (southward) and Khamardaban (northward) zones. 


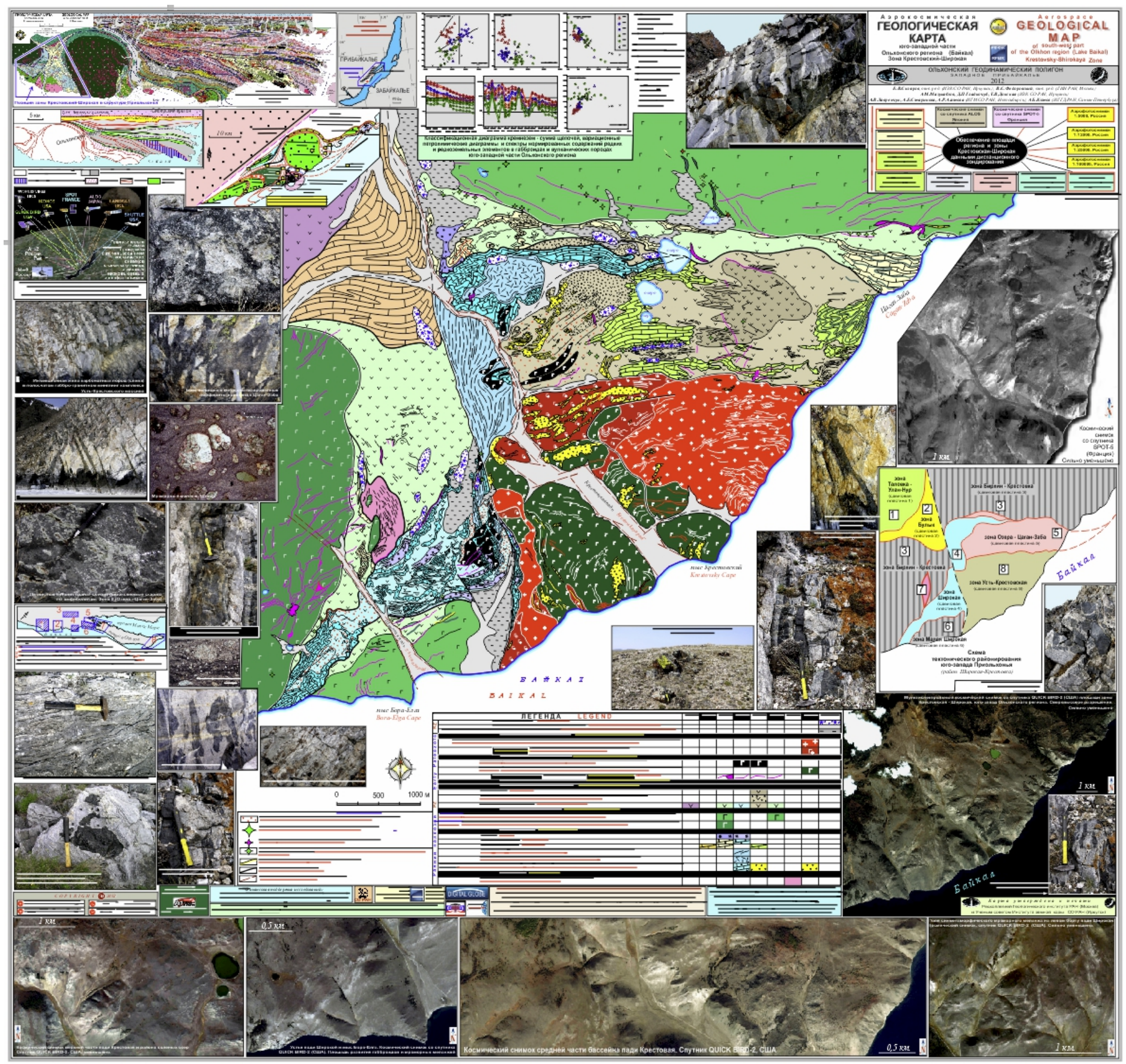

Рис. 21. Аэрокосмическая геологическая карта юго-западной части Ольхонского региона (Байкал).

Зона Крестовский - Широкая. Ольхонский геодинамический полигон.

Fig. 21. The aero-space geological map of the south-western part of the Olkhon region (Baikal).

The Krestovsky-Shirokaya zone. The Olkhon geodynamic test area.

тины в отложениях голоустенской свиты байкальской серии (рис. 19), а именно в прослое аргиллитов, сформировавшемся во время резкого перехода от оледенения Гаскье к стадии постледникового теплого климата. В связи с тем, что типичных, с точки зрения гипотезы «Snowball Earth», повышенных концентраций космической пыли (маркирующейся повышенными концен- трациями элементов платиновой группы) в исследуемых образцах обнаружено не было, был сделан вывод либо о кратком характере оледенения Гаскье, либо о его региональной распространенности [Ivanov et al., 2013].

3.2.3. Детально изучена геохимия метавулканитов Тункинского террейна (рис. 20), расположенного в 

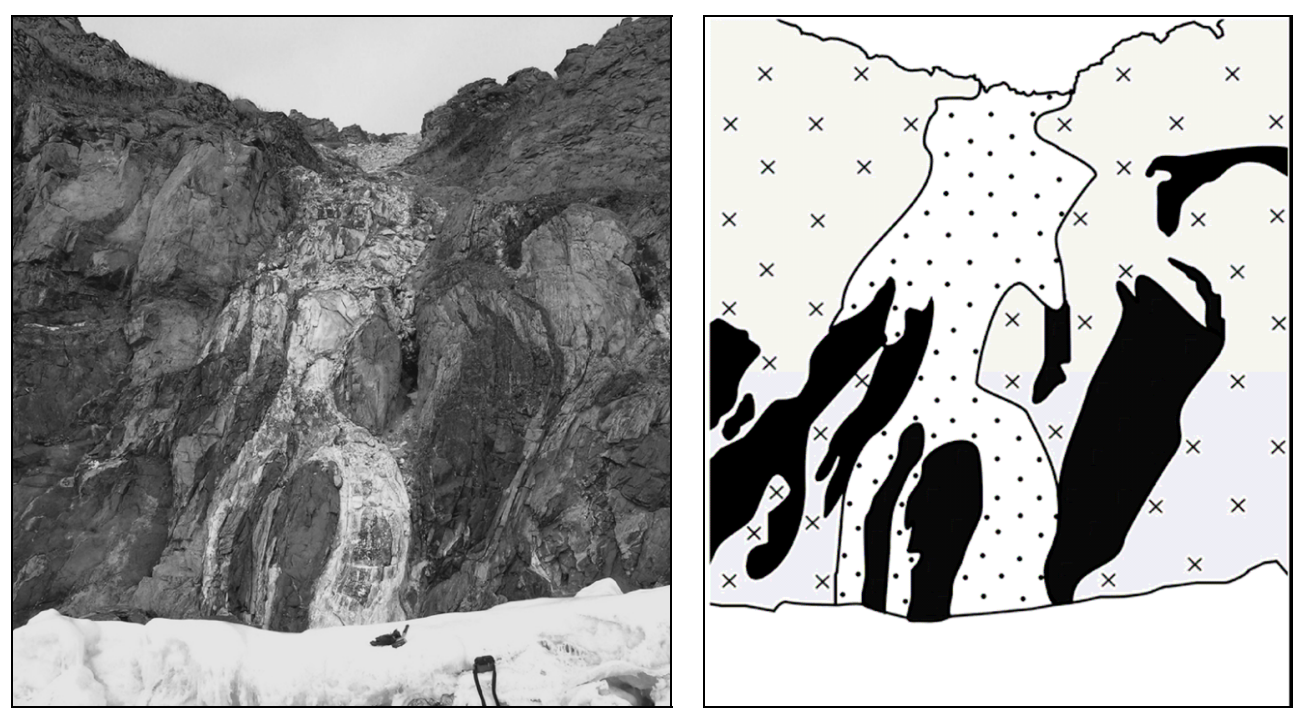

Рис. 22. Фотография и зарисовка по фотографии жилы бруситовых мраморов, прорывающей сиениты с тектонизированной дайкой субщелочных габбро (Тажеранский массив).

Fig. 22. A photo and a drawing based on the photo of the brucite marble vein cutting through syenites with the tectonic dyke of subalkaline gabbro in the Tazheran massif.
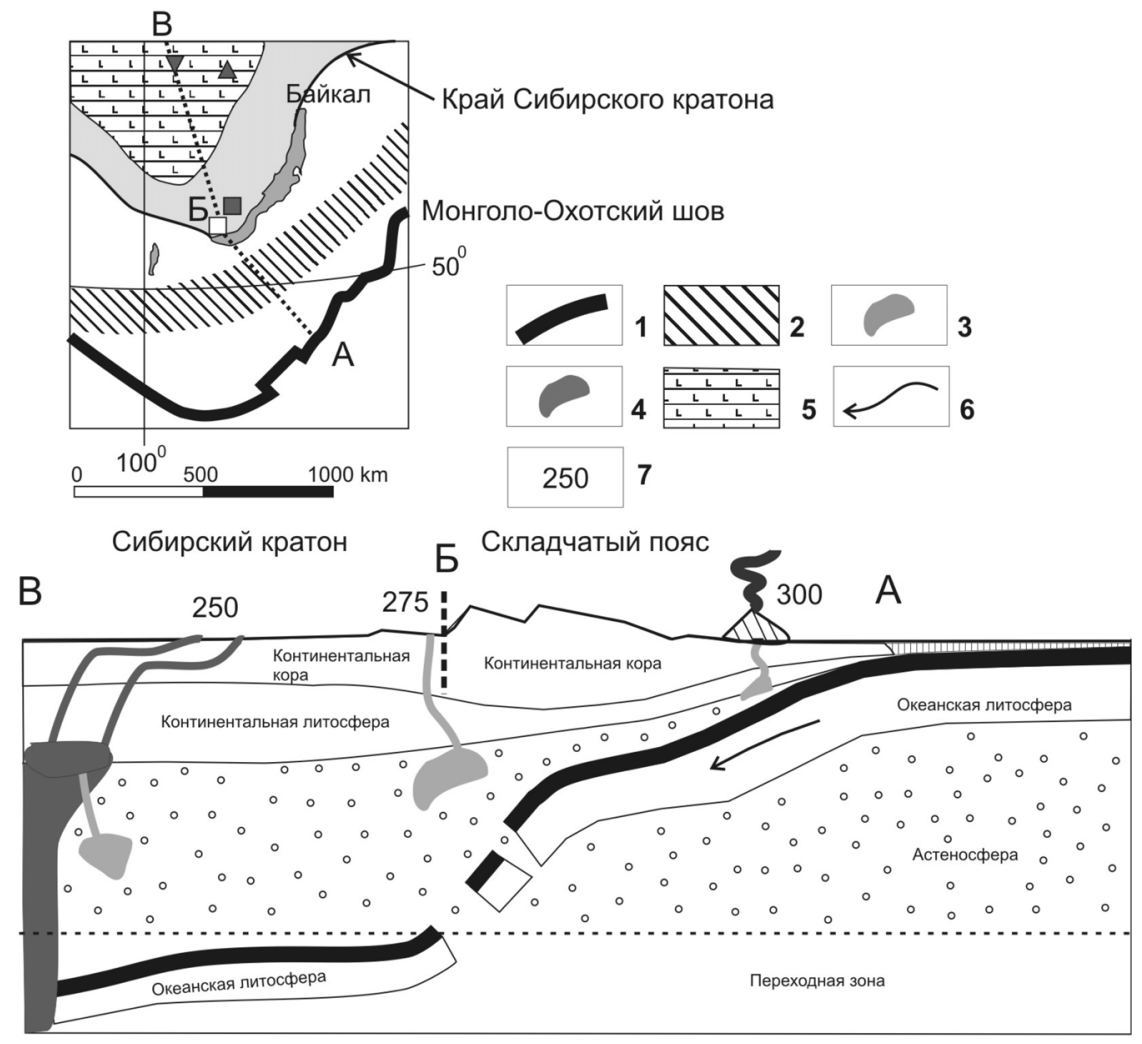

Рис. 23. Модель магматизма позднего палеозоя - раннего мезозоя в пределах южного фланга Сибирского кратона и в прилегающих областях ЦАСП.

1 - субдуцируемый слэб; 2 - вулканоплутонические ассоциации позднего палеозоя на площади ЦАСП; 3 - субдукционно обогащенные источники; 4 - вещество Сибирского суперплюма; 5 - поле развития раннемезозойских траппов (Ангаро-Тасеевская синеклиза); 6 - направление движения субдуцируемой плиты Монголо-Охотского океана; 7 - возраст магматических событий.

Fig. 23. The Late Paleozoic magmatism model of the southern flank of the Siberian craton and the neighbouring regions of the Central Asian folded belt (CAFB).

1 - subduction slab; 2 - Late Paleozoic volcano-plutonic associations in the territory of CAFB; 3 - sources saturated due to subduction; 4 - material of the Siberian super-plume; 5 - field where the Early Mesozoic trapps are developed (Angara-Taseevskaya syncline); 6 - movement direction of the subduction plate of the Mongol-Okhotsk Ocean; 7 - age of magmatic occurrences. 
северо-восточной части Центрально-Азиатского складчатого пояса.

Установлено, что протолиты метавулканитов представлены рядом базальт-андезибазальт-андезит. Основная геохимическая особенность метавулканитов различная степень обогащения несовместимыми элементами относительно N-MORB и отсутствие ярко выраженных аномалий по $\mathrm{Nb}$, что позволяет классифицировать их как базальтоиды задуговых бассейнов. Происхождение первичных базальтовых магм связывается с частичным плавлением мантийного источника, близкого к шпинелевому перидотиту в области мантийного клина, метасоматически проработанного в связи с дегидратацией субдуцирующей океанической плиты и контаминированного при подплавлении дегидратированного слэба [Школьник и др., 2009].

3.2.4. Установлена близость геохимических составов метавулканитов, выявленных в центральной части Тункинских гольцов, к составам, имеющим бонинитовую и пикритовую специфику. Наличие базальтоидов как с выраженной отрицательной, так и с положительной $\mathrm{Nb}$ аномалией, а также совместное нахождение данных пород в разрезе с серпентинитами могут маркировать древнюю зону спрединга задугового бассейна в пределах Тункинского террейна. Предложены модели, объясняющие присутствие двух геохимически различающихся типов вулканитов. Один вариант - результат плавления двух исходных мантийных источников. Нельзя исключить также неодновременность образования высоко- и низкотитанистых вулканитов. Возможно, деплетированные вулканиты образовывались на более ранних стадиях, в период максимального раскрытия задугового бассейна с активным спредингом. Обогащенные разности вулканитов могли отвечать более поздним стадиям, когда обстановка спрединга (растяжения) сменилась субдукционной (сжатия), маркирующейся в вулканитах 1-й группы высокими содержаниями крупноионных литофильных и легких редкоземельных элементов относительно высокозарядных элементов и выраженными отрицательными $\mathrm{Nb}, \mathrm{Ti}$ аномалиями. Нельзя полностью исключить и возможность их формирования в разных частях активной окраины с последующим тектоническим совмещением. Таким образом, с учетом одной из последних интерпретаций структуры Саяно-Байкальской складчатой области [Зорин и др., 2009], можно считать, что Тункинский террейн является составной частью задугового бассейна активной островодужной окраины, а примитивные высокомагнезиальные метавулканиты маркируют задуговый палеоспрединг [Школьник и др., 2011].

3.2.5. На примере Ольхонской коллизионной системы показана связь субщелочного мантийного магматизма со сдвиговой тектоникой при коллизионном тектогенезе. Характерной особенностью внедрения базитовых магм является их тесная ассоциация с салическими породами (граниты, сиениты) корового проис- хождения, что обусловило широкое проявление процессов минглинга. Для Ольхонской системы характерно широкое проявление комбинированных даек базитгранитного состава. Возраст этих даек составляет 463 млн лет. В пределах Тажеранского массива тела пластовой и конической формы тесно ассоциируют с сиенитами и карбоналитами (продуктами плавления коровых карбонатных толщ), являясь более поздними по отношению к безнефелиновым сиенитам и субсинхронными с нефелиновыми сиенитами и карбоналитами. Предполагается, что глубокопроникающие сдвиги дренируют мантию, обуславливая проникновение мантийных магм через «горячую» вязко-пластическую матрицу глубинных частей коры на поздних стадиях коллизионного процесса. Термальное состояние нижней коры способствует процессам ее частичного плавления и внедрения продуктов плавления в верхние горизонты вместе с базитами [Федоровский и др., 2010].

3.2.6. На основании детального картирования составлена карта масштаба 1:12500 юго-западной части Ольхонского региона (Зона Крестовский - Широкая) (рис. 21). Принципиально новыми результатами, отраженными на этой карте, являются: 1) выделение Бирхинской вулканоплутонической ассоциации с возрастом около 500 млн лет; 2) обоснование факта широкого распространения минглинга как в дайках, так и в более крупных телах; 3) доказательство широкого распространения инъекционных карбонатных и карбонатно-силикатных пород, к наиболее характерным представителям которых относятся зоны мраморного меланжа и жилы в магматических и метаморфических комплексах [Скляров и др., 2012].

3.2.7. В пределах Ольхонской коллизионной системы раннего палеозоя (Западное Прибайкалье) выделено два типа инъекционных карбонатных и карбонатносиликатных пород: синметаморфический мраморный меланж и жильные тела в амфиболитах, габброидах и сиенитах (рис. 22). Для мраморного меланжа характерно присутствие разноразмерных обломков силикатных пород (кристаллические сланцы, гнейсы, метагаббро, граниты). Жильные тела кальцитового, доломитового состава и карбонатно-силикатных пород характеризуются массивной текстурой и мелкозернистым строением. Нередко они ассоциируют с субсинхронными жилами гранитов и дайками долеритов, обнаруживая иногда признаки карбонатно-силикатного минглинга. Для этих жил предполагается внедрение порций карбонатного или карбонатно-силикатного состава на поздних стадиях синметаморфического тектогенеза. По своим изотопно-геохимическим и минералогическим характеристикам эти карбонатные породы отличаются от мантийных карбонатитов, и, скорее всего, их образование связано с плавлением осадочных карбонатных пород в нижней коре в присутствии водного флюида. Процессы сдвигового тектогенеза способствовали дренированию нижней коры и верхней мантии и обеспечивали поступление на верхние уров- 
(a) $\mathrm{D}_{2}-\mathrm{C}$

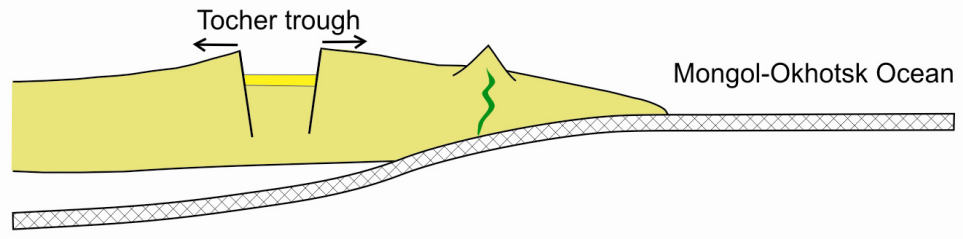

Angara-Vitim batholith

(b) $\mathrm{C}_{1-2}$

(c) $\mathrm{C}_{2}-\mathrm{P}_{1}$

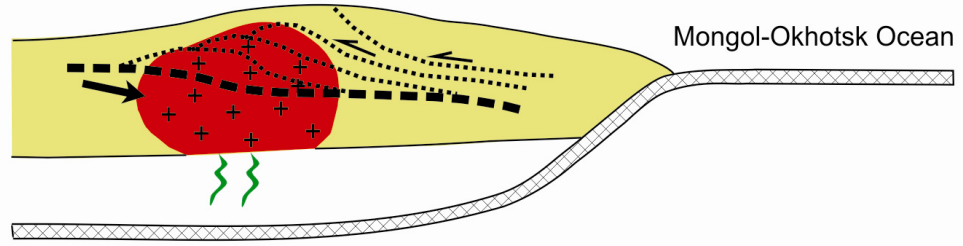

Western

Angara-Vitim Transbaikalian
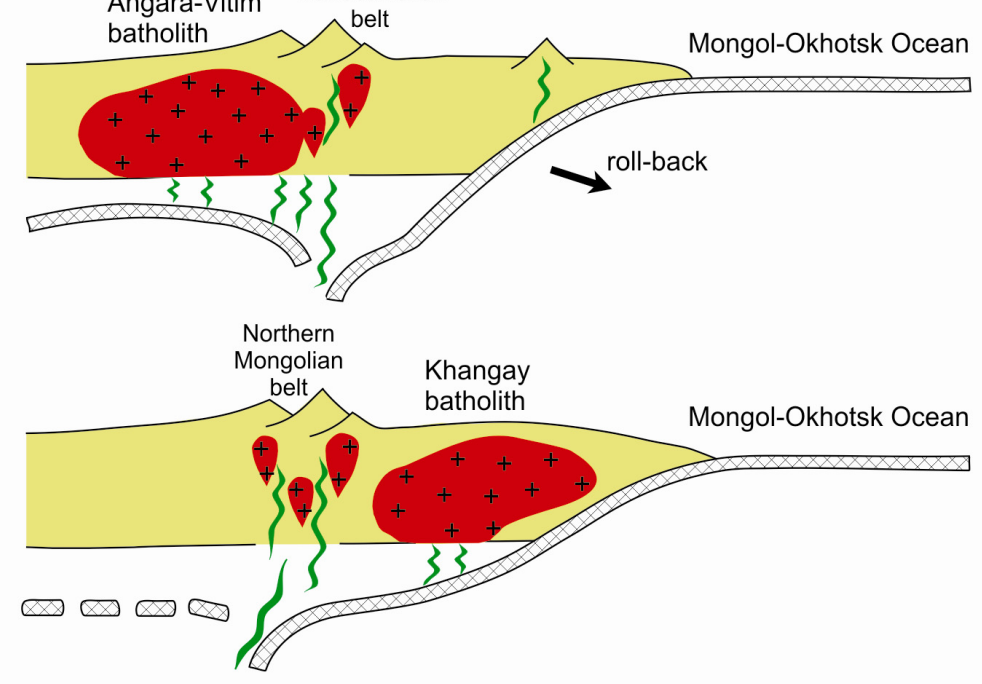

(d) $P_{3}-T_{2}$

(e) $T_{3}$

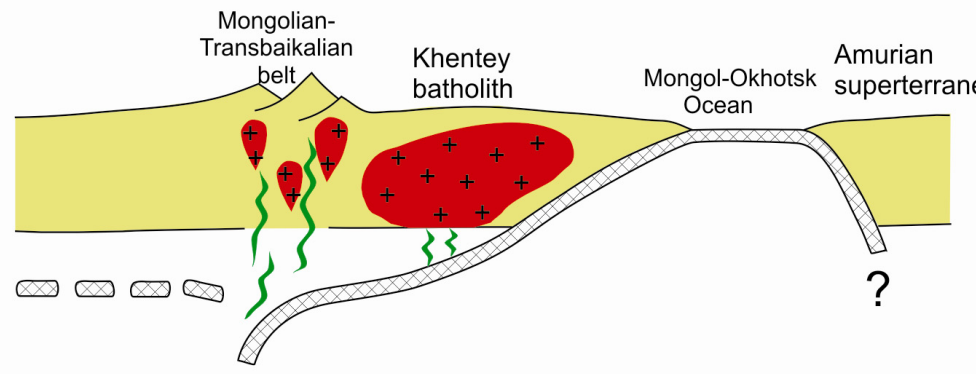

(f) $J_{3}$

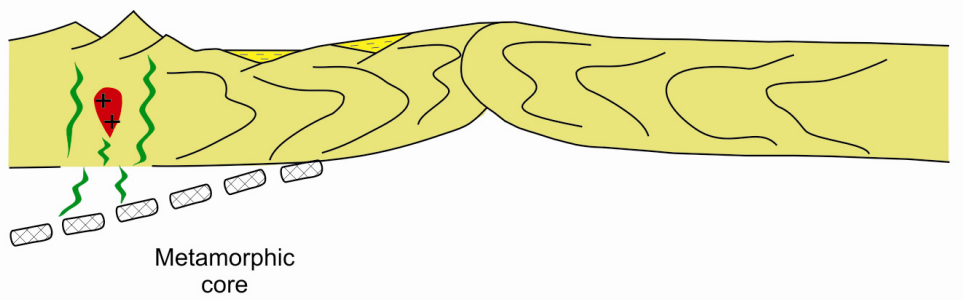

(g) $\mathrm{K}_{1}$

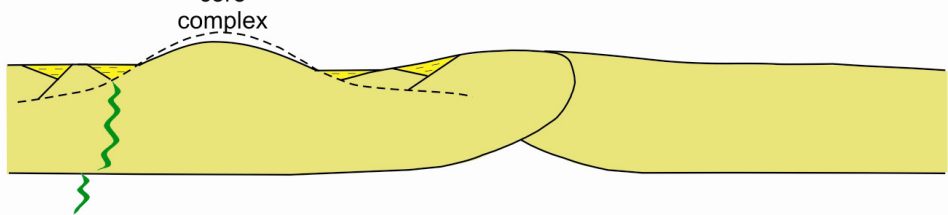

Рис. 24. Модель эволюции забайкальского сегмента ЦАСП в позднем палеозое - мезозое [Donskaya et al., 2013].

Fig. 24. The model of evolution of the Transbaikalian segment of CAFB in the Late Paleozoic - Mesozoic, according to [Donskaya et al., 2013]. 
D.P. Gladkochub, E.Kh. Turutanov: The deep structure and paleogeodynamics of Siberia and Central Asia...

ни коры карбонатного материала в виде выплавок и вязко-пластических смесей, равно как и коровых гранитов, а также порций мантийных базитовых расплавов. Инъекционные карбонатные породы описаны и в других метаморфических комплексах, в том числе в каледонидах Норвегии и в пределах Гималайской коллизионной системы [Скляров и др., 2013].

\section{3. ГЕОДИНАМИКА ОБЛАСТИ СОЧЛЕНЕНИЯ СИБИРСКОГО КРАТОНА И ЦЕНТРАЛЬНО-АЗИАТСКОГО СКЛАДЧАТОГО ПОЯСА}

3.3.1. Для южного фланга Сибирского кратона обосновано выделение трех основных этапов фанерозойского базитового магматизма. Установлено, что первое событие фиксируется дайками долеритов с возрастом около 500 млн лет, внедрение которых происходило на фоне аккреционно-коллизионных событий, связанных с начальными этапами становления Центрально-Азиатского складчатого пояса, когда на южном фланге Сибирского кратона, выступающем в качестве индентера, возникали области рассеянного растяжения, способствующие внедрению базитовых расплавов в верхние горизонты коры. Позднепалеозойский этап базитового магматизма фиксируется дайками с возрастом около 275 млн лет. Подобные дайки, в совокупности с несколько более древними (290 млн лет) вулканическими образованиями забайкальского сегмента ЦАСП, маркируют процессы растяжения, имевшие место в тылу активной окраины Сибирского континента на фоне субдукции под нее коры МонголоОхотского океана. Трапповый магматизм раннего мезозоя на юге Сибирского кратона проявлен многочисленными базитовыми интрузиями Ангаро-Тасеевской синеклизы с возрастом 240-245 млн лет. Образование траппов происходило при взаимодействии вещества нижнематийного плюма с материалом слэба МонголоОхотского океана.

Показано, что более молодой возраст траппов, по сравнению с вышерассмотренными базитами позднего палеозоя (290-275 млн лет), отражает прогрессирующее продвижение слэба под южной окраиной Сибирского кратона (в северо-западном направлении в современных координатах), прекратившееся, по-видимому, после достижения слэбом области распространения вещества Сибирского суперплюма (рис. 23). Сделано предположение о том, что отсутствие последующих магматических событий на юге Сибирского кратона обусловлено тем, что после раннемезозойской активизации произошла окончательная консолидация литосферы рассматриваемого фрагмента кратона, препятствующая развитию в его пределах условий растяжения, благоприятных для внедрения базитовых интрузий [Гладкочуб и др., 2010].

3.3.2. Синтез геологических, геохимических и геохронологических данных по магматическим образованиям как основного, так и кислого состава в пределах северного сегмента Центрально-Азиатского складчатого пояса позволяет предложить следующую геодинамическую модель развития активной континентальной окраины с варьирующимся во времени наклоном погружающегося океанического слэба и влиянием горячей точки мантии (рис. 24) [Donskaya et al., 2013].

В девоне, после завершения раннепалеозойских орогенных событий, началось пологое погружение океанического слэба под венд-раннепалеозойскую окраину Сибирского континента.

Ранне-позднекарбоновый период характеризуется сменой режима растяжения на сжатие, что привело к формированию складчато-надвиговых деформаций, развитию дуплекс-структур и в завершение - к утолщению континентальной коры. На этой стадии произошло формирование автохтонных биотитовых гранитов Ангаро-Витимского батолита в утолщенной континентальной коре.

Позднекарбоновый - раннепермский этап характеризуется деструкцией океанического слэба с откатом его в сторону желоба. В результате этого возникли условия для растяжения континентальной литосферы и проникновения мантийного вещества в верхние горизонты коры. В течение этого периода был сформирован основной объем гранитоидов Ангаро-Витимского батолита, а также щелочные гранитоиды, вулканиты и многочисленные дайки основного и кислого состава Западно-Забайкальского пояса. Формирование магматических образований этого этапа может быть связано с растяжением в пределах утолщенной континентальной коры.

Позднепермский - позднетриасовый период характеризуется разнообразным интрузивным и эффузивным магматизмом над погружающейся под нормальным углом зоной субдукции. Позднепермские - среднетриасовые известково-щелочные гранитоиды Хангайского батолита и позднетриасовые известково-щелочные гранитоиды Хентейского батолита были внедрены вблизи Монголо-Охотской сутуры, в то время как щелочные гранитоиды и бимодальные вулканические серии формировались во внутренней части континента в условиях растяжения над разрушающимся слэбом.

Юрский период характеризуется значительным уменьшением магматической активности в пределах северного сегмента ЦАСП. Возможно, это связано с прекращением субдукции океанической коры Монголо-Охотского океана в западной части океанического бассейна.

Раннемеловой период характеризуется закрытием Монголо-Охотского океана в его восточной части. В Забайкалье и Северной Монголии в течение этого временного интервала начался коллапс Монголо-Охотского орогена и формирование комплексов метаморфических ядер.

3.3.3. Получены результаты, позволяющие определить время проявления основных тектонических пере- 


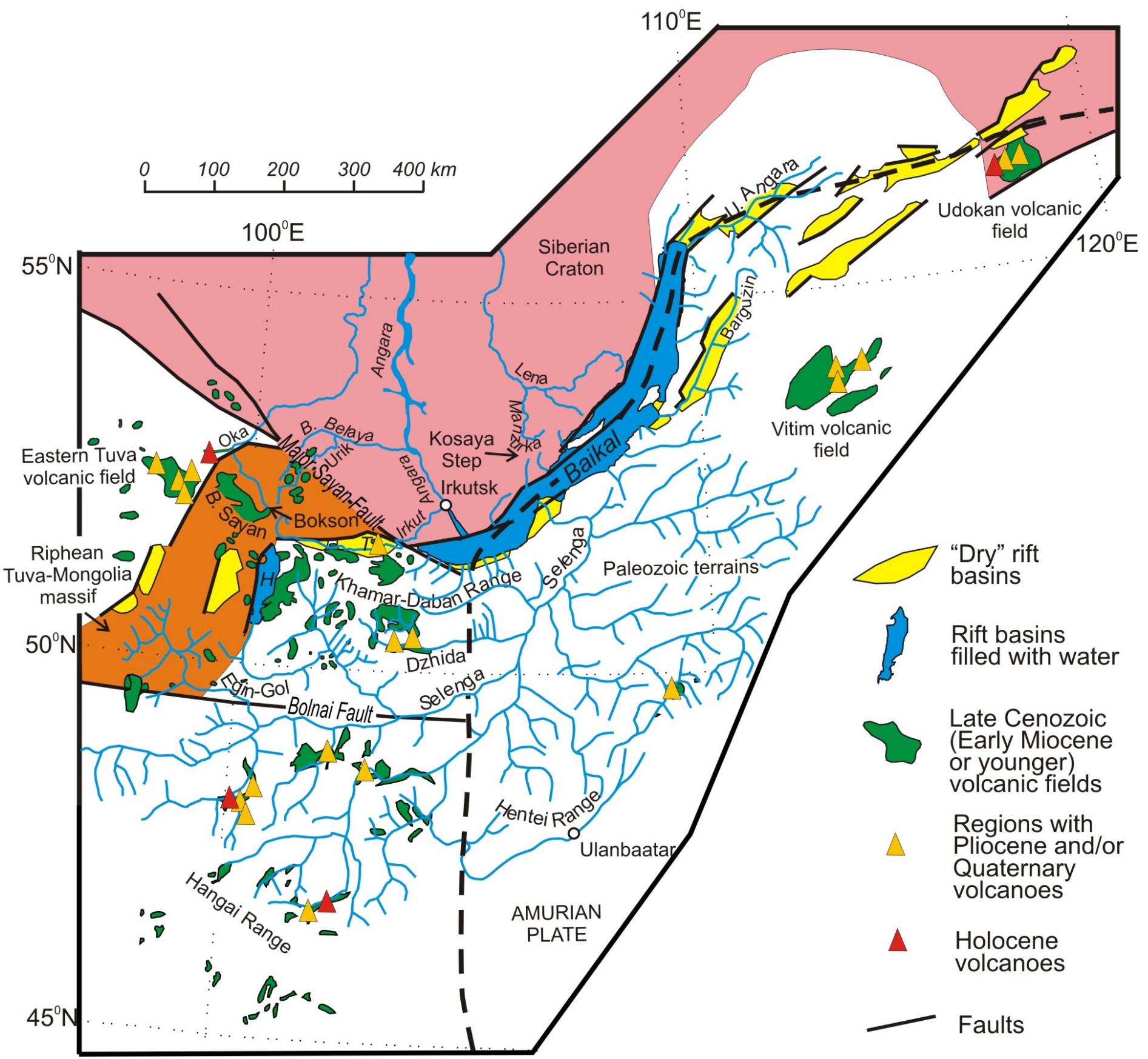

| Рис. 25. Байкальская рифтовая система и сопредельные регионы.

I Fig. 25. The Baikal rift system and neighbouring regions.

строек в Байкальской рифтовой зоне (рис. 25). Выявлен ранее не описанный эпизод воздымания и расчленения рельефа, имевший место около 20 млн лет назад. Весьма вероятно, что современная структура речной сети на юго-западе Байкальской рифтовой системы начала формироваться именно в результате этого тектонического эпизода. Лавы с возрастом $\sim 8$ млн лет в Западном Прихубсугулье заполняли хорошо выраженные речные палеодолины, которые впоследствии были разнесены на разные гипсометрические уровни при вертикальных тектонических движениях по рифтокон- тролирующим разломам. Таким образом, формирование Хубсугульской рифтовой впадины началось после этого эпизода вулканизма.

Сделан вывод о том, что, несмотря на то, что раннемиоценовые лавы на сегодняшний день находятся на вершинах гор, в момент излияния они заполняли речные долины глубиной не менее 100 м [Ivanov, Demonterova, 2009].

3.3.4. Получена наиболее полная запись тектонической истории по изучению осадочных кернов, отобранных с подводного Академического хребта в ходе 


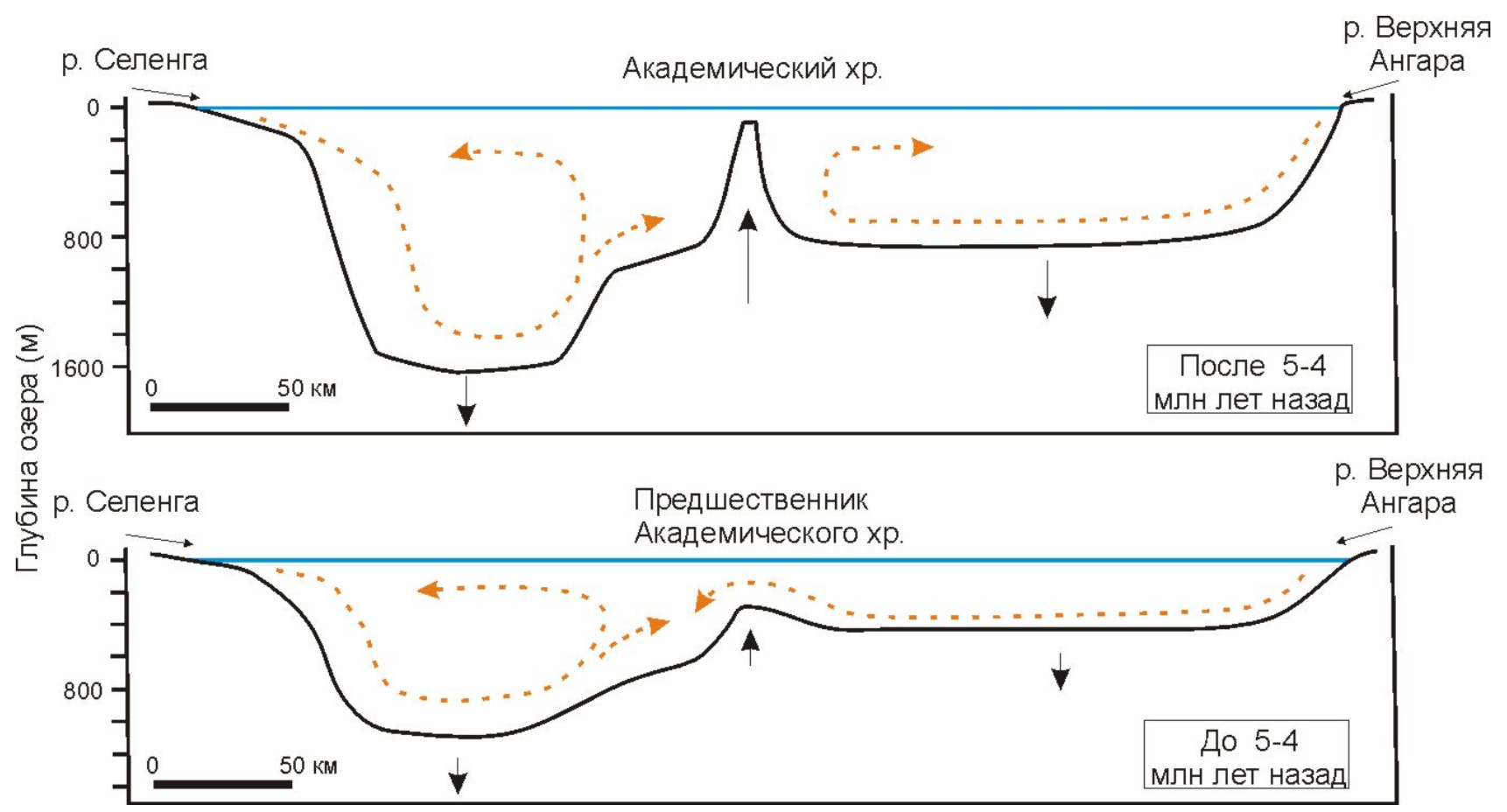

Рис. 26. Изменение условий осадконакопления на подводном Академическом хребте в результате его воздымания и углубления впадин [Ivanov, Demonterova, 2009].

Fig. 26. Changes of sedimentation conditions at the underwater Academic ridge which result from its uplift and deepening of basins, according to [Ivanov, Demonterova, 2009].

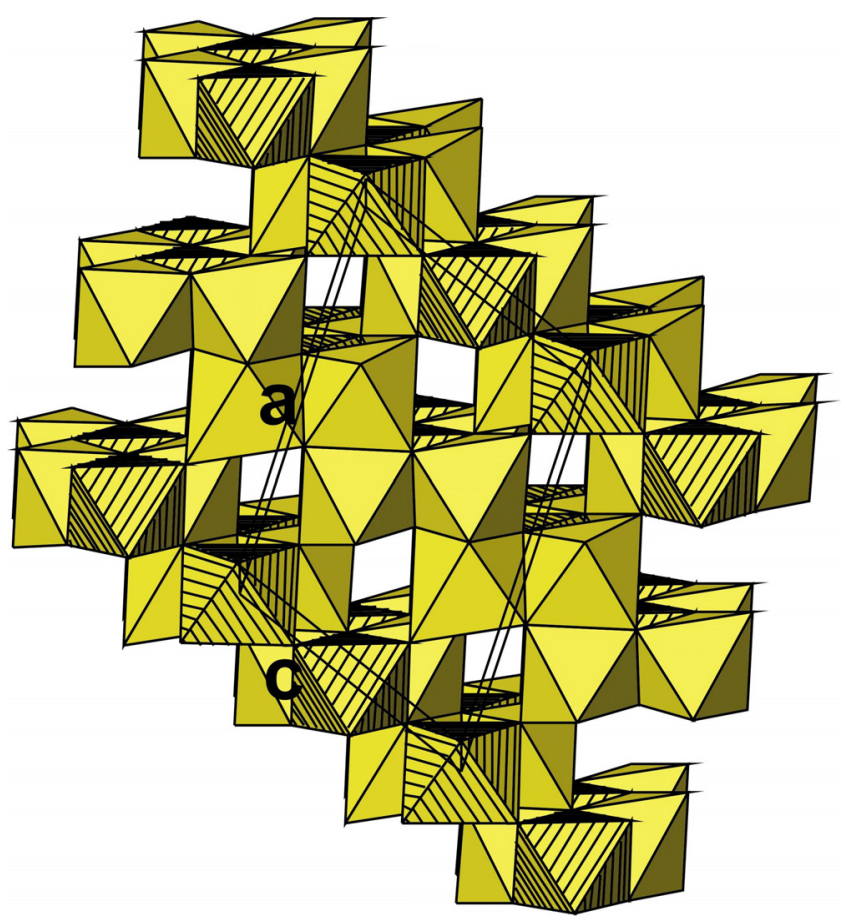

Рис. 27. Кристаллическая структура оксиванита.

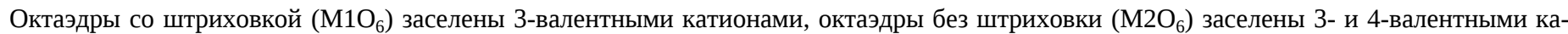
тионами.

Fig. 27. The crystalline structure of oxivanite.

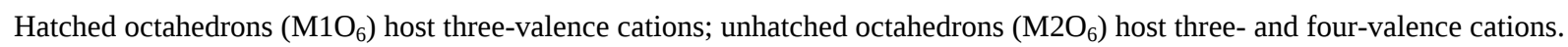


проекта «Байкал-бурение». В этой записи отчетливо видны три тектонических события, произошедшие около 7, 5 и 0.1 млн лет назад. Первое из них характеризуется увеличением скорости осадконакопления, что, по-видимому, связано с ростом гор, сопутствующим разрастанию рифта от его исторического центра в районе Южно-Байкальской впадины на фланги (рис. 26). В это время, очевидно, началось формирование Хубсугульской впадины. Второе событие, наоборот, маркируется практически двукратным снижением скорости осадконакопления. Столь резкое снижение скорости осадконакопления может быть объяснено своеобразным расположением подводного Академического хребта, с которого отобраны осадочные керны. Второе тектоническое событие отражает смену от стадии «медленного» к стадии «быстрого» рифтогенеза. Третье, наиболее позднее, событие фиксируется по изменению изотопного состава диатомовых и терригенных осадков. Рост ${ }^{87} \mathrm{Sr} /{ }^{86} \mathrm{Sr}$ отношений связан с увеличением поступления терригенного вещества в озеро в результате увеличения скорости эрозии при росте гор, ускорившемся из-за таяния ледников. Этот рост гор, в частности, привел к прекращению стока из озера Байкал через палеореку Манзурка в реку Лена и появлению современного стока через реку Ангара. По данным термолюминесцентного датирования манзурских осадков в районе поселка Косая Степь сток из Байкала в Лену происходил еще в позднем плейстоцене, приблизительно 100 тыс. лет назад. Таким образом, по данным изучения времени щелочно-базальтовых извержений, положения датированных лав в палео- и современном рельефе, а также анализа скорости осадконакопления во впадинах и состава осадков в Байкальской рифтовой системе фиксируется четыре основных тектонических перестройки - около 20, 7, 5 и 0.1 млн лет назад [Ivanov, Demonterova, 2009].

\section{4. НОВЫЕ МИНЕРАЛЫ И ИХ РОЛЬ В РЕКОНСТРУКЦИИ ГЕОДИНАМИЧЕСКИХ РЕЖИМОВ}

3.4.1. Открыт новый минерал - оксиванит (рис. 27), который получил одобрение Комиссии по новым минералам PMO и утвержден Комиссией по новым минералам, номенклатуре и классификации Международной минералогической ассоциации (IMA 2008044). Решена кристаллическая структура оксиванита и оксиванита-бердесинскиита.Установлено, что она аналогична структуре синтетического высокотемпературного $\mathrm{V}_{3} \mathrm{O}_{5}$ и подобна структурам синтетических $\mathrm{Fe}_{2} \mathrm{TiO}_{5}, \mathrm{CrTi}_{2} \mathrm{O}_{5}, \mathrm{Ti}_{3} \mathrm{O}_{5}, \mathrm{Cr}_{2} \mathrm{TiO}_{5}$. Эту структуру можно представить как плотнейшую гексагональную упаковку атомов кислорода, в которой 3/5 октаэдрических интерстиций заселены трех- и четырехвалентными катионами $\left(\mathrm{V}^{3+}\right.$ и $\mathrm{V}^{4+}$ в $\left.\mathrm{V}_{3} \mathrm{O}_{5}\right)$. Связанные ребрами катионсодержащие октаэдры образуют тройные цепочки, вытянутые по [010]. Стержень цепочек составляют октаэдры $M 1$, образующие общие входящие углы и об- щие ребра с незначительно наклоненными прилегающими октаэдрами M2. Позиции M1 оккупируются трехвалентными, а позиции $M 2$ - трех- и четырехвалентными катионами. В структурном типе оксиванита и бердесинскиита цепочки складываются в лестничноподобную (ступенчатую) конструкцию. Связь цепочек реализуется через общие плоскости прилегающих октаэдров $M 2$ с образованием общих углов с плоскостями октаэдров M1. Лестнично-подобная, ступенчатая морфология связанных цепочек ответственна за моноклинную симметрию оксиванита [Armbruster et al., 2009].

3.4.2. В метаморфических породах слюдянского комплекса Южного Прибайкалья открыт новый минерал купрокалининит $\mathrm{CuCr}_{2} \mathrm{~S}_{4}$ (утвержден KHМ MMA, меморандум 2010-008). Купрокалининит относится к редкой в природе группе минералов, так называемым халькогенидным шпинелям, в которых кислород замещен селеном, теллуром или серой. В последнем случае подгруппа выделяется как сульфошпинели. Особенно редки хромовые сульфошпинели. Купрокалининит - третья хромовая сульфошпинель, открытая в земных породах (рис. 28). При редкости в природе, халькогенидные шпинели интенсивно синтезируются и изучаются в физике и химии твердых тел, поскольку отличаются большим диапазоном и сильной взаимосвязью оптических, магнитных и электрических свойств (ферри-, ферро- и антиферромагнетики, полупроводники, металлы, сверхпроводники). Тиохромат меди, природным аналогом которого является купрокалининит, выделяется среди других сульфошпинелей необычным сочетанием ферромагнетизма с металлической проводимостью, что стабильно привлекает внимание исследователей [Резницкий и др., 2010].

3.4.3. Установлено, что клинопироксены Cr-Vсодержащих параметаморфических пород слюдянского кристаллического (гранулитового) комплекса представлены тройной серией твердых растворов диопсид $\mathrm{CaMgSi}_{2} \mathrm{O}_{6}$ - космохлор $\mathrm{NaCrSi}_{2} \mathrm{O}_{6}-$ наталиит $\mathrm{NaVSi}_{2} \mathrm{O}_{6}$, включающей наряду с тройными смесями бинарные изоморфные ряды. Из них наиболее детально проанализирован непрерывный ряд диопсид-космохлор в диапазоне от $\mathrm{Di}_{100}$ до $\mathrm{Kos}_{94}\left(\mathrm{Cr}_{2} \mathrm{O}_{3} 30.83\right.$ мас. \%) (рис. 29). Непрерывный, без разрыва смесимости полный ряд установлен впервые. На основании реакционных взаимоотношений эсколаита с диопсидом сделан вывод, что образование космохлора и высокохромистых членов ряда произошло за счет метаморфического эсколаита в связи с привносом натрия после этапа прогрессивного метаморфизма. Низкая скорость диффузии (амобильность) хрома обусловила незавершенность реакций образования космохлора, неоднородность состава зерен клинопироксенов и совместное присутствие в породах разных членов ряда диопсидкосмохлор. Следовательно, хромистость клинопироксена в метаморфитах лимитируется не непосредственно Р-Т-параметрами процесса и ограниченной 


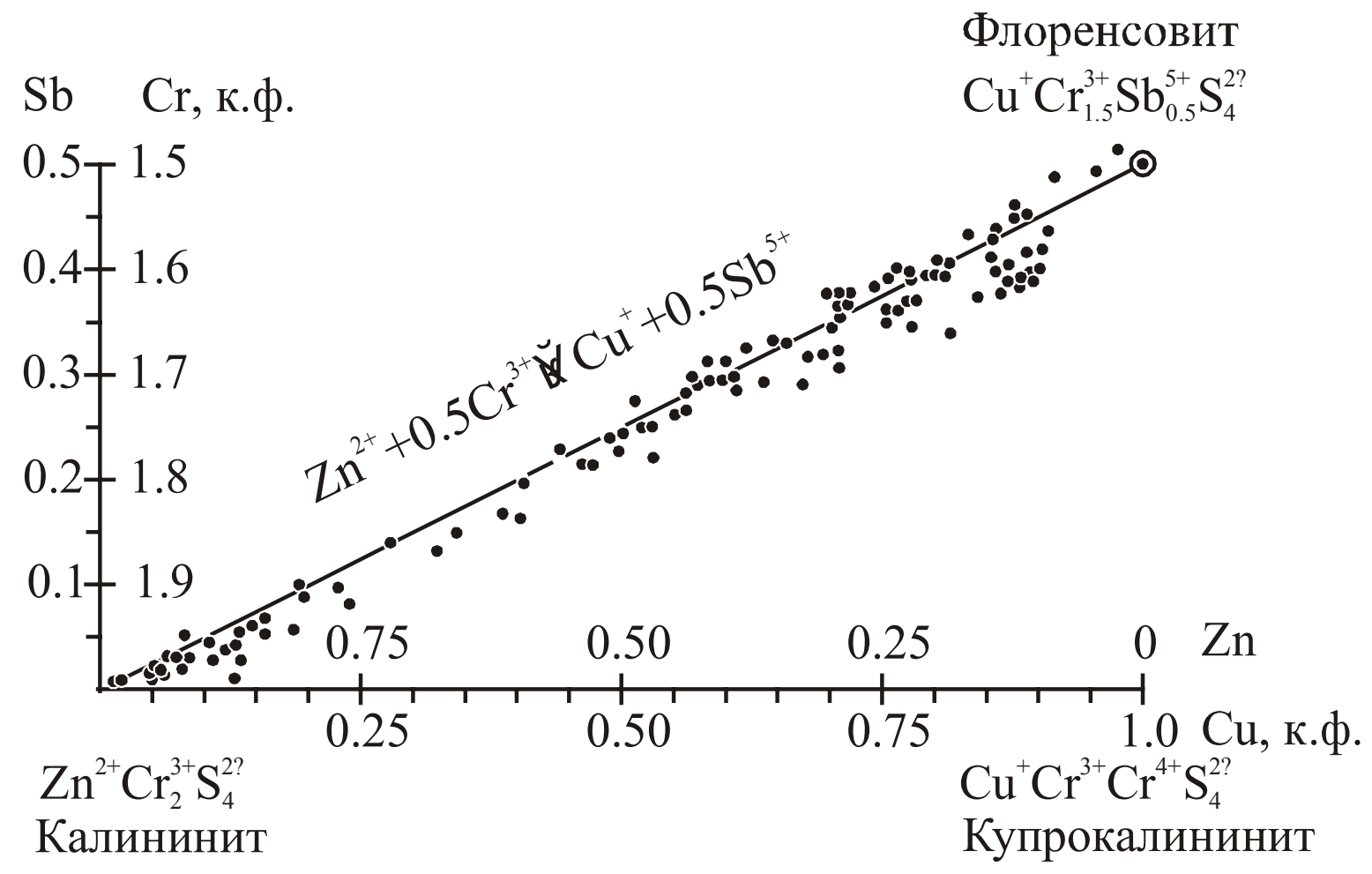

І Рис. 28. Соотношения трех хромовых сульфошпинелей, известных в земных породах.

Fig. 28. Ratios between the three chrome sulfospinels common for the Earth rocks.

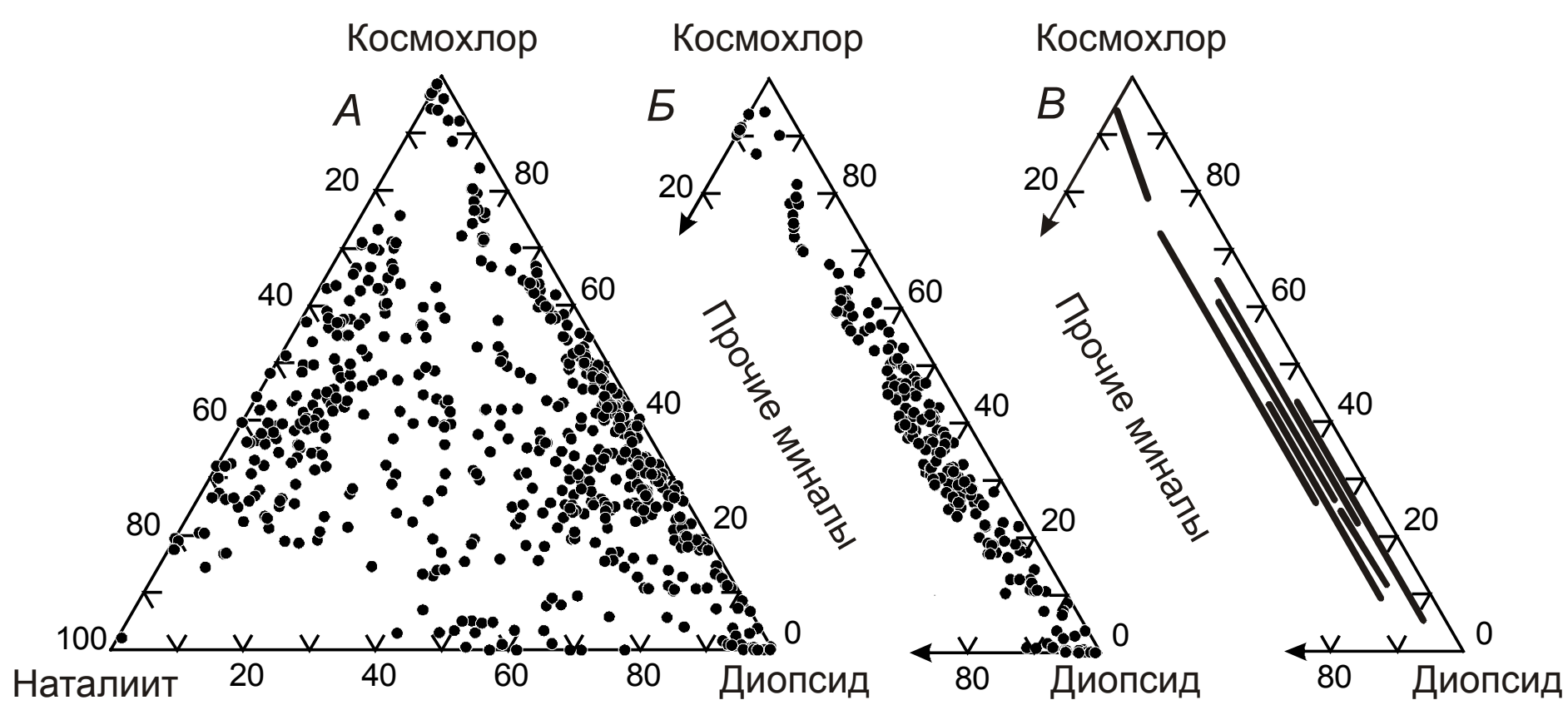

Рис. 29. Компонентный состав Cr-V-содержащих клинопироксенов слюдянского комплекса (мол. \%).

$A$ - соотношение наталиитового, космохлорового и диопсидового миналов. $Б$ - ряд диопсид-космохлор. $B$ - диапазоны диопсидкосмохлор, установленные в отдельных монокристальных зернах.

Fig. 29. Composition of Cr-V-bearing clinopyroxenes of the Slyudyanka complex (mol. \%).

$A$ - ratio between nataliite, cosmochlore and diopside minals. $\overline{-}$ - diopside-cosmochlore row. $B$ - diopside-cosmochlore ranges revealed for individual and single-crystal grains. 

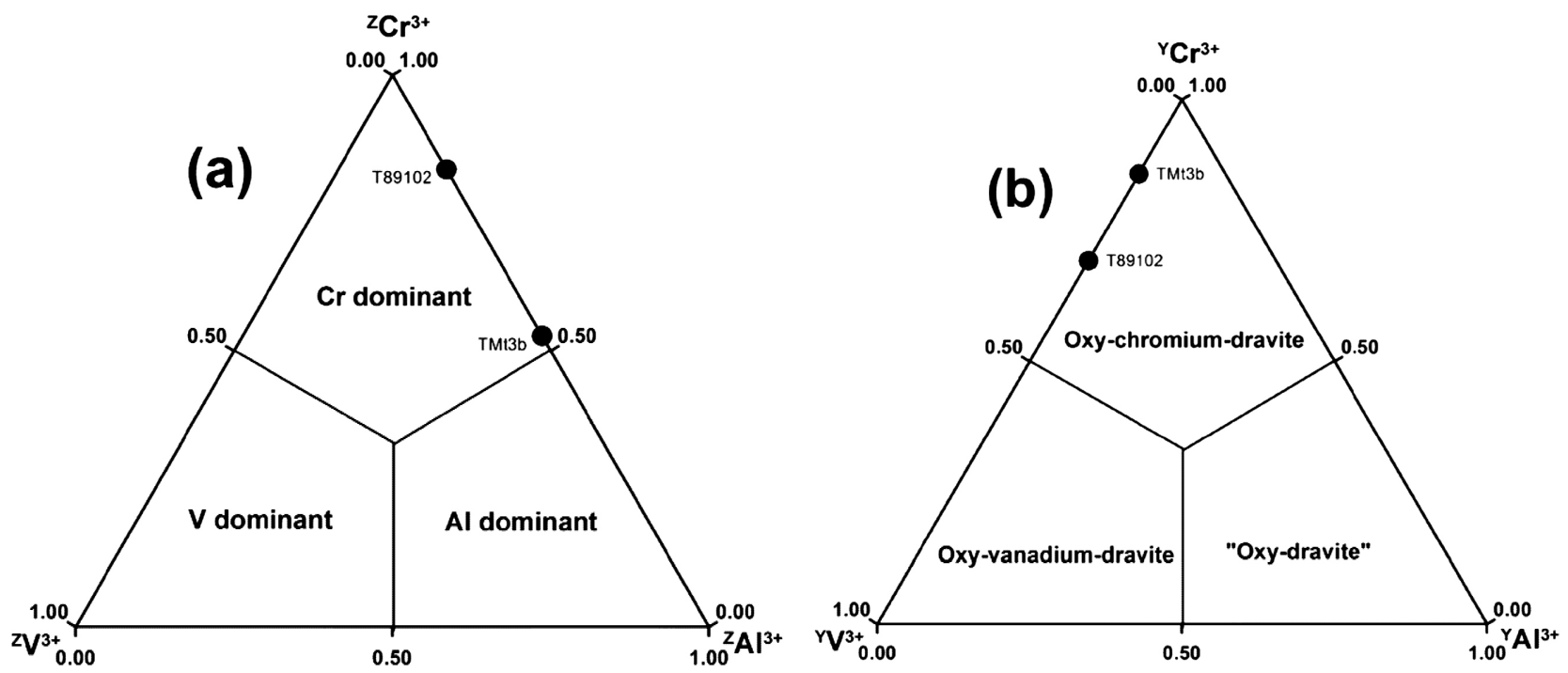

Рис. 30. Тройные диаграммы для подсистемы Al-V-Cr, показывающие положение окси-хромдравита в позициях Z (a) и Y $(b)$.

Fig. 30. Triple diagrams for Al-V-Cr subsystem showing the position of oxi-chromedravite in positions Z (a) and Y (b).
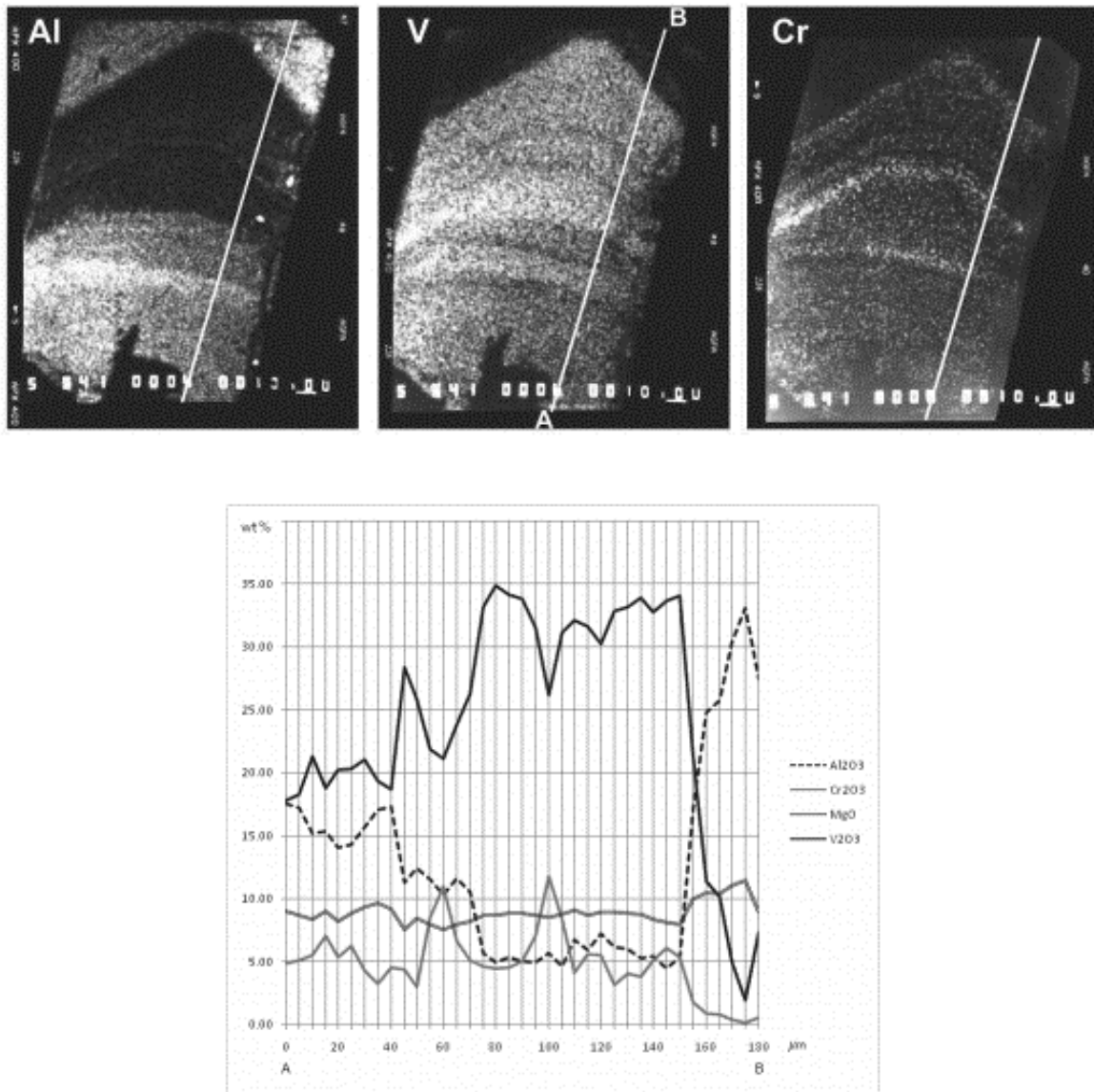

Рис. 31. Зональный кристалл Al-Cr-V-окси-турмалина, иллюстрирующий переходы от окси-ванадиум-дравита к хром- и алюминий-доминантным окси-турмалинам.

Fig. 31. A zonal crystal of Al-Cr-V-oxi-turmaline that illustrates transition from oxi-vanadium-dravite to chrome- and aluminumdominant oxi-turmalines. 
взаимной растворимостью твердого раствора диопсидкосмохлор, а кинетическими факторами. Анализ литературных данных по другому типу метаморфических пород, высокобарным, преимущественно апоультрабазитовым, обнаруживает подобный механизм образования космохлора и космохлорсодержащих клинопироксенов - замещение магматического хромита при привносе натрия [Резницкий и др., 2011].

3.4.4. В метаморфических породах слюдянского комплекса открыт новый минерал из группы турмалина окси-хромдравит $\mathrm{NaCr}_{3}\left(\mathrm{Cr}_{4} \mathrm{Mg}_{2}\right)\left(\mathrm{Si}_{6} \mathrm{O}_{18}\right)\left(\mathrm{BO}_{3}\right)_{3}(\mathrm{OH})_{3} \mathrm{O}$. Его отличительными особенностями является преобладание хрома в структурных позициях $\mathrm{Y}$ и $\mathrm{Z}$ и кислорода в позиции W (рис. 30) [Bosi et al., 2012].

3.4.5. На основе монокристальных рентгеноструктурных исследований произведено уточнение структуры ванадиодравита. В соответствии с новой классификацией и по согласованию с Комиссией по новым минералам и названиям новых минералов изменена формула и уточнено название: окси-ванадиумдравит $\mathrm{Na}\left(\mathrm{V}_{3}\right)\left(\mathrm{V}_{4} \mathrm{Mg}_{2}\right) \mathrm{Si}_{6} \mathrm{O}_{18}\left(\mathrm{BO}_{3}\right)_{3}(\mathrm{OH})_{3} \mathrm{O}$ (рис. 31). Из этой же серии окси-турмалинов изучен новый турмалин - железосодержащий хромо-алюмино-повондраит. В окситурмалинах реализуется гетеровалентный компенсационный изоморфизм $\mathrm{Mg}+\mathrm{O} \leftrightarrow \mathrm{Cr}, \mathrm{V}+\mathrm{OH}$. Турмалины этого типа являются индикаторами кислородного режима (оксибарометрами) [Bosi et al., 2013a, 2013b].

Перспективы развития лаборатории видятся как в сохранении и совершенствовании методик, которые уже успешно реализуются на базе института, так и в освоении новых передовых наработок. Среди приоритетов в этом направлении может быть отмечено развитие термохронологии с использованием U-Th-Pb-He метода для датирования неотектонических событий, определения возраста поднятия к поверхности магматических интрузий (и кимберлитовых тел), фиксации начала процессов диагенеза, сопряженного с формированием низкотемпературных рудных месторождений.

Отдельное внимание в работах лаборатории будет уделяться возрождению рудной тематики, направленной на изучение процессов рудогенеза, в том числе ответственных за формирование крупных и гигантских месторождений полезных ископаемых. Как известно, формирование подобных месторождений неразрывно связано как с глубинными процессами, так и с конкретными геодинамическими обстановками (режимами). В связи с этим, изучение вопросов, касающихся геодинамического контроля формирования и размещения месторождений полезных ископаемых на площади Сибирского кратона и в пределах ЦентральноАзиатского складчатого пояса, представляется перспективным направлением, способным укрепить баланс между фундаментальными исследованиями и инновационными направлениями, развиваемыми в лаборатории палеогеодинамики.

Всего за период с 2009 по 2013 г. по теме НИР опубликовано 10 монографий, 4 карты, 32 статьи в зарубежных и 80 статей в российских научных журналах. Перечень основных публикаций приводится ниже.

\section{4. СПИСОК ОСНОВНЫХ РАБОТ ПО ТЕМЕ НИР «ГЛУБИННОЕ СТРОЕНИЕ И ГЕОДИНАМИЧЕСКАЯ ЭВОЛЮЦИЯ ЮЖНОГО ФЛАНГА СИБИРСКОГО КРАТОНА И ПРИЛЕГАЮЩИХ ОБЛАСТЕЙ ЦЕНТРАЛЬНО- АЗИАТСКОГО СКЛАДЧАТОГО ПОЯСА», ОПУБЛИКОВАННЫХ ЛАБОРАТОРИЯМИ КОМПЛЕКСНОЙ ГЕОФИЗИКИ И ПАЛЕОГЕОДИНАМИКИ В 2009-2013 ГГ.}

\section{1. МОНОГРАФИИ}

Байкаловедение: Учебник для студентов естественнонаучных специальностей университетов в 2 кн. Раздел в монографии: Гладчочуб Д.П., Мазукабзов А.М., Донская Т.В. Глава 4. Геологическое строение и геодинамика Прибайкалья. Новосибирск: Наука, 2012. Кн. 1. 468 с. С. 301-335.

Бямба Ж., Арвисбаатар Н., Турутанов Е.Х. Глубинное строение Монголии // Геология Монголии. T. IV. Тектоника литосферных плит. Улаанбаатар: Изд-во АДМОН, 2009. С. 403-425 (Глава в монографии на монгольском языке. 1-е издание).

Бямба Ж., Арвисбаатар Н., Турутанов Е.Х. Глубинное строение Монголии // Геология Монголии. T. IV. Tектоника литосферных плит. Улаанбаатар: Изд-во АДМОН, 2012. С. 403-425 (Глава в монографии на монгольском языке. 2-е издание).

Имаева Л.П., Мельникова В.И., Имаев В.С., Козьмин Б.М., Мельников А.И., Гриб Н.Н. Эволюция сейсмотектонических процессов северо-восточного фланга Байкальской рифтовой зоны. Иркутск: Институт земной коры СО PAH, 2012. 232 c.

Никольский Ф.В., Анисимова С.А., Титоренко Т.Н., Гелетий Н.К. Региональная тектоника. Морфология и генезис складчатой структуры Байкало-Патомского нагорья и Приленского плато: Учебное пособие. Иркутск: Изд-во Иркутского государственного университета, 2013. 72 с.

Скляров Е.В., Дорофеева Р.П. Институт земной коры: люди, события, даты, 1949-2009. Иркутск, ИЗК СО РАН, 2009. 672 c.

Турутанов Е.X. Строение кайнозойских впадин северо-восточного и юго-западного окончаний Байкальской рифтовой системы по гравиметрическим данным. Иркутск: Изд-во ИрГТУ, 2010. 167 с. 
Турутанов Е.X. Морфология базитовых интрузий Ольхонского региона по гравимагнитным данным (Западное Прибайкалье). Иркутск: Изд-во ИрГТУ, 2011. 208 с.

Турутанов Е.X. Морфология мезозойских гранитных плутонов Монголии по гравиметрическим данным. Иркутск: Изд-во ИрГТУ. 2012. 223 с.

Чароит. Сиреневое чудо Сибири. Иллюстрированное научно-популярное издание. Иркутск: Изд-во Петрографика, 2013. 192 c.

\section{2. КАРТЫ}

Скляров Е.В. (отв. ред.), Федоровский В.С. (отв. ред.), Мазукабзов А.М., Гладкочуб Д.П., Донская Т.В., Лавренчук A.В., Старикова А.Е., Агатова А.Р., Котов А.Б. Аэрокосмическая геологическая карта юго-западной части Ольхонского региона (Байкал). Зона Крестовский - Широкая. Ольхонский геодинамический полигон. М.: Группа компаний A1 TIS, 2012

Федоровский В.С. (отв. ред.), Мазукабзов А.М., Скляров Е.В., Гладкочуб Д.П., Донская Т.В., Лавренчук А.В., Изох А.Э., Агатова А.Р., Котов А.Б. Аэрокосмическая геологическая карта юго-западной части зон Черноруд и Томота Ольхонского региона (Байкал). Ольхонский геодинамический полигон. М.: Группа компаний A1 TIS, 2012.

Федоровский В.С., Скляров Е.В., Мазукабзов А.М., Гладкочуб Д.П., Донская Т.В., Лавренчук А.В., Изох А.Э., Агатова A.P., Котов А.Б. Аэрокосмическая геологическая карта северо-восточной части Приольхонья (Байкал). Зоны Нутгей и Оргойта-Змеиная падь. Ольхонский геодинамический полигон. М.: Группа компаний A1 TIS, 2011.

Федоровский В.С., Скляров Е.В., Мазукабзов А.М., Котов А.Б., Каргополов С.А., Лавренчук А.В., Старикова А.Е. Геологическая карта массива Тажеран. М.: Группа компаний A1 TIS, 2009.

\section{3. СТАТЬИ В ЗАРУБЕЖНЫХ РЕФЕРИРУЕМЫХ ЖУРНАЛАХ}

Anisimova S.A., Gelety N.K., Anisimov A.Y., Dol'nik T.A., de Boisgrollier T., 2012. Sedimentary Precambrian deposits in southwestern Transbaikalia (Siberia): phytoliths content, lateral correlations and geodynamics. Global Geology 15 (3), 85-96.

Armbruster T., Galuskin E.V., Reznitsky L.Z., Sklyarov E.V., 2009. X-ray structural investigation of the oxyvanite $\left(\mathrm{V}_{3} \mathrm{O}_{5}\right)-$ berdesinskiite $\left(\mathrm{V}_{2} \mathrm{TiO}_{5}\right)$ series: $\mathrm{V}^{4+}$ substituting for octahedrally coordinated $\mathrm{Ti}^{4+}$. European Journal of Mineralogy 21 (4), 885-891. http://dx.doi.org/10.1127/0935-1221/2009/0021-1951.

Armbruster T., Lazic B., Reznitsky L.Z., Sklyarov E.V., 2013. Kyzylkumite, $\mathrm{Ti}_{2} \mathrm{~V}^{3+} \mathrm{O}_{5}(\mathrm{OH})$ : new structure type, modularity and revised formula. Mineralogical Magazine 77 (1), 33-44. http://dx.doi.org/10.1180/minmag.2013.077.1.04.

Blanko D., Kravchinsky V.A., Konstantinov K.M., Kabin K., 2013. Paleomagnetic dating of Phanerozoic kimberlites in Siberia. Journal of Applied Geophysics 88, 139-153. http://dx.doi.org/10.1016/j.jappgeo.2012.11.002.

Bosi F., Reznitskii L.Z., Sklyarov E.V., 2013. Oxy-vanadium-dravite, $\mathrm{NaV}_{3}\left(\mathrm{~V}_{4} \mathrm{Mg}_{2}\right)\left(\mathrm{Si}_{6} \mathrm{O}_{18}\right)\left(\mathrm{BO}_{3}\right)_{3}(\mathrm{OH})_{3} \mathrm{O}$ : Crystal structure and redefinition of the "vanadium-dravite" tourmaline. American Mineralogist 98, 501-505. http://dx.doi.org/10.2138/ am.2013.4243.

Bosi F., Reznitskii L., Skogby H., 2012. Oxy-chromium-dravite, $\mathrm{NaCr}_{3}\left(\mathrm{Cr}_{4} \mathrm{Mg}_{2}\right)\left(\mathrm{Si}_{6} \mathrm{O}_{18}\right)\left(\mathrm{BO}_{3}\right)_{3}(\mathrm{OH})_{3} \mathrm{O}$, a new mineral species of the tourmaline supergroup. American Mineralogist 97, 2024-2030. http://dx.doi.org/10.2138/am.2012.4210.

Bosi F., Skogby H., Hålenius U., Reznitskii L.Z., 2013. Crystallographic and spectroscopic characterization of Fe-bearing chromo-alumino-povondraite and its relations with oxy-chromium-dravite and oxy-dravite. American Mineralogist 98, 1557-1564. http://dx.doi.org/10.2138/am.2013.4447.

Courtillot V., Kravchinsky V.A., Quidelleur X., Renne P.R., Gladkochub D.P., 2010. Preliminary dating of the Viluy traps (Eastern Siberia): Eruption at the time of Late Devonian extinction events? Earth and Planetary Science Letters 300, 239-245. http://dx.doi.org/10.1016/j.epsl.2010.09.045.

Daoudene Y., Gapais D., Ledru P., Cocherie A., Hocquet S., Donskaya T.V., 2009. The Ereendavaa Range (north-eastern Mongolia): an additional argument for Mesozoic extension throughout eastern Asia. International Journal of Earth Sciences 98, 1381-1393. http://dx.doi.org/10.1007/s00531-008-0412-2.

de Boisgrollier T., Petit C., Fournier M., Leturmy P., Ringenbach J.-C., San'kov V.A., Anisimova S.A., Kovalenko S.N., 2009. Palaeozoic orogeneses around the Siberian craton: Structure and evolution of the Patom belt and foredeep. Tectonics 28, TC1005. http://dx.doi.org/10.1029/2007TC002210.

Didenko A.N., Vodovozov V.Yu., Pisarevsky S.A., Gladkochub D.P., Donskaya T.V., Mazukabzov A.M., Stanevich A.M., Bibikova E.V., Kirnozova T.I., 2009. Palaeomagnetism and U-Pb dates of the Palaeoproterozoic Akitkan Group (South Siberia) and implication for the pre-Neoproterozoic tectonics. Geological Society of London Special Volume «Palaeoproterozoic Supercontinents and Global Evolution» 23, 224-241. http://dx.doi.org/10.1144/SP323.7.

Donskaya T.V., Gladkochub D.P., Pisarevsky S.A., Poller U., Mazukabzov A.M., Bayanova T.B., 2009. Discovery of Archaean crust within the Akitkan orogenic belt of the Siberian craton: new insight into its architecture and history. Precambrian Research 170, 61-72. http://dx.doi.org/10.1016/j.precamres.2008.12.003.

Donskaya T.V., Gladkochub D.P., Mazukabzov A.M., Ivanov A.V., 2013. Late Paleozoic - Mesozoic subduction-related magmatism at the southern margin of the Siberian continent and the 150 million-year history of the Mongol-Okhotsk Ocean. Journal of Asian Earth Science 62, 79-97. http://dx.doi.org/10.1016/j.jseaes.2012.07.023. 
Gladkochub D., Donskaya T., 2009. Overview of geology and tectonic evolution of the Baikal-Tuva area. Biosilica in Evolution, Morphogenesis, and Nanobiology (W.E.G. Müller and M.A. Grachev, eds.), Marine Molecular Biotechnology 47, 726. http://dx.doi.org/10.1007/978-3-540-88552-8_1.

Gladkochub D.P., Donskaya T.V., Reddy S.M., Poller U., Bayanova T.B., Mazukabzov A.M., 2009. Palaeoproterozoic to Eoarchaean crustal growth in southern Siberia: a Nd-isotope synthesis. Geological Society of London, Special Volume «Palaeoproterozoic Supercontinents and Global Evolution» 23, 127-143. http://dx.doi.org/10.1144/SP323.6.

Gladkochub D.P., Donskaya T.V., Wingate M.T.D., Mazukabzov A.M., Pisarevsky S.A., Sklyarov E.V., Stanevich A.M., 2010. A one-billion-year gap in the Precambrian history of the southern Siberian Craton and the problem of the Transproterozoic supercontinent. American Journal of Sciences 310, 812-825. http://dx.doi.org/10.2475/09.2010.03.

Gladkochub D.P., Pisarevsky S.A., Donskaya T.V., Ernst R.E., Wingate M.T.D., Söderlund U., Mazukabzov A.M., Sklyarov E.V., Hamilton M.A., Hanes J.A., 2010. Proterozoic mafic magmatism in Siberian craton: An overview and implications for paleocontinental reconstruction. Precambrian Research 183, 660-668. http://dx.doi.org/10.1016/j.precamres.2010. 02.023.

Ivanov A.V., Demonterova E.I., 2009. Tectonics of the Baikal rift deduced from volcanism and sedimentation: A review oriented to the Baikal and Hovsgol Lake systems. Biosilica in Evolution, Morphogenesis, and Nanobiology (W.E.G. Müller and M.A. Grachev, eds.), Marine Molecular Biotechnology 47, 27-54. http://dx.doi.org/10.1007/978-3-540-88552-8_2.

Ivanov A.V., Gladkochub D.P., Deverchere J., Ernst R.E., 2013. Introduction to special issue: Geology of the Lake Baikal region. Journal of Asian Earth Sciences 62, 1-3. http://dx.doi.org/10.1016/j.jseaes.2012.12.010.

Ivanov A.V., He H., Yan L., Ryabov V.V., Shevko A.Y., Palesskii S.V., Nikolaeva I.V., 2013. Siberian Traps Large Igneous Province: Evidence for two flood basalt pulses around the Permo-Triassic boundary and in the Middle Triassic, and contemporaneous granitic magmatism. Earth-Science Reviews 122, 58-76. http://dx.doi.org/10.1016/j.earscirev.2013.04. 001.

Ivanov A.V., He H., Yang L., Nikolaeva I.V., Palesskii S.V., 2009. ${ }^{40} \mathrm{Ar} /{ }^{39} \mathrm{Ar}$ dating of intrusive magmatism in the AngaraTaseevskaya syncline and its implication for duration of magmatism of Siberian Traps. Journal of Asian Earth Sciences 35, 1-12. http://dx.doi.org/10.1016/j.jseaes.2008.11.006.

Ivanov A.V., Mazukabzov A.M., Stanevich A.M., Palesskiy S.V., Kozmenko O.N., 2013. Testing the snowball Earth hypothesis for the Ediacaran. Geology 41, 787-790. http://dx.doi.org/10.1130/G34345.1.

Jolivet M., T. De Boisgrollier, Petit C., Fournier M., Sankov V.A., Ringenbach J.-C., Byzov L., Miroshnichenko A.I., Kovalenko S.N., Anisimova S.V., 2009. How old is the Baikal Rift Zone? Insight from apatite fission track thermochronology. Tectonics 28, TC3008. http://dx.doi.org/10.1029/2008TC002404.

Kovach V., Salnikova E., Wang K-L., Jahn B-M., Chiu H-Y., Reznitskiy L., Kotov A., Iizuka Y., Chung S-L., 2013. Zircon ages and Hf isotopic constraints on sources of clastic metasediments of the Slyudyansky high-grade complex, southeastern Siberia: Implication for continental growth and evolution of the Central Asian Orogenic Belt. Journal of Asian Earth Sciences 62, 18-36. http://dx.doi.org/10.1016/j.jseaes.2011.08.008.

Kravchinsky V.A., Sklyarov E.V., Gladkochub D.P., Harbert W.P., 2010. Paleomagnetism of the Precambrian Eastern Sayan rocks: Implications for the Ediacaran-Early Cambrian paleogeography of the Tuva-Mongolian composite terrane. Tectonophysics 486 (1-4), 65-80. http://dx.doi.org/10.1016/j.tecto.2010.02.010.

Li Z.X., Bogdanova S.V., Collins A.S., Davidson A., De Waele B., Ernst R.E., Fitzsimons I.C.W., Fuck R.A., Gladkochub D.P., Jacobs J., Karlstrom K.E., Lu S., Natapov L.M., Pease V., Pisarevsky S.A., Thrane K., Vernikovsky V.A., 2009. How not to assemble a Precambrian supercontinent. A reply to J.D.A. Piper. Precambrian Research 174, 208-214. http://dx.doi. org/10.1016/j.precamres.2009.06.007.

Pisarevsky S.A., Gladkochub D.P., Konstantinov K.M., Mazukabzov A.M., Stanevich A.M., Murphy J.B., Tait J.A., Donskaya T.V., 2013. Konstantinov I.K. Paleomagnetism of Cryogenian Kitoi mafic dykes in South Siberia: Implications for Neoproterozoic paleogeography. Precambrian Research 231, 372-382. http://dx.doi.org/10.1016/j.precamres.2013.04. 007.

Powerman V., Shatsillo A., Coe R., Zhao X., Gladkochub D., Buchwaldt R., Pavlov V., 2013. Palaeogeography of the Siberian platform during middle Palaeozoic Times ( 450-400Ma): new palaeomagnetic evidence from the Lena and Nyuya rivers. Geophysical Journal International 194, 1412-1440. http://dx.doi.org/10.1093/gji/ggt197.

Radziminovich N.A., Gileva N.A., Melnikova V.I., Ochkovskaya M.G., 2013. Seismicity of the Baikal rift system from regional network observations. Journal Of Asian Earth Sciences 62, 146-161. http://dx.doi.org/10.1016/j.jseaes.2012. 10.029 .

Rojas-Agramonte Y., Kröner A., Demoux A., Xia X., Wang W., Donskaya T., Liu D., Sun M., 2011. Detrital and xenocrystic zircon ages from Neoproterozoic to Palaeozoic arc terranes of Mongolia: Significance for the origin of crustal fragments in the Central Asian Orogenic Belt. Gondwana Research 19 (3), 751-763. http://dx.doi.org/10.1016/j.gr.2010.10.004.

Safonova I., Seltman R., Gladkochub D., Kim J., Komiya T., Kroener A., Schulmann K., Sun M., Xiao W., 2011. A new concept of continental construction in the Central Asian orogenic belt (compared to actualistic examples from the Western Pacific). Episodes 34 (3), 186-196.

Wang T., Zheng Y., Zhang J., Zeng L., Donskaya T., Guo L., Li J., 2011. Pattern and kinematic polarity of late Mesozoic extension in continental NE Asia: perspectives from metamorphic core complexes. Tectonics 30, TC6007. http://dx.doi.org/ 10.1029/2011TC002896.

Wingate M.T.D., Pisarevsky S.A., Gladkochub D.P., Donskaya T.V., Konstantinov K.M., Mazukabzov A.M., Stanevich A.M., 2009. Geochronology and paleomagnetism of mafic igneous rocks in the Olenek Uplift, northern Siberia: Implications for 
Mesoproterozoic supercontinents and paleogeography. Precambrian Research 170, 256-266. http://dx.doi.org/10.1016/ j.precamres.2009.01.004.

\section{4. СТАТЬИ В РОССИЙСКИХ РЕФЕРИРУЕМЫХ ЖУРНАЛАХ}

Ivanov A.V., 2010. Deep-level geodynamics: boundaries of the process according to geochemic and petrologic data. Geodynamics \& Tectonophysics 1 (1), 87-102.

Reznitsky L.Z., Sklyarov E.V., Armbruster T., Suvorova L.F., Ushchapovskaya Z.F., Kanakin S.V., 2013. Kyzylkumite: A finding in the Southern Baikal Region, Russia and Refinement of Its Crystal Chemical Formula. Geology of Ore Deposits 55 (8), 107-120.

Reznitsky L.Z., Sklyarov E.V., Armbruster T., Ushchapovskaya Z.F., Galuskin E.V., Polekhovsky Yu.S., Barash I.G., 2010. Oxyvanite, $\mathrm{V}_{3} \mathrm{O}_{5}$, a New Mineral Species and the Oxyvanite-Berdesinskiite $\mathrm{V}_{2} \mathrm{TiO}_{5}$ Series from Metamorphic Rocks of the Slyudyanka Complex, Southern Baikal Region. Geology of Ore Deposits 52 (7), 1-10.

Sklyarov E.V., Rasskazov S.V., Yasnygina T.A., 2010. Cenozoic Continental Rifting Symposium dedicated to the memory of Academician N.A. Logatchev, Irkutsk, Russia, June 7-11, 2010. Geodynamics \& Tectonophysics 1 (3), 322-329.

Stanevich A.M., Mashchuk I.M., Mazukabzov A.M., Postnikov A.A., Kornilova T.A., 2010. The southern fragment of the Siberian craton: "landscape" history over two billion years. Geodynamics \& Tectonophysics 1 (1), 103-118.

Агеенков Е.В., Давыденко Ю.А., Фомицкий В.А. Влияние неосевого расположения приемной и питающей электрических линий на результаты дифференциально-нормированного метода электроразведки // Геология и геофизика. 2012. T. 53. № 1. С. 150-157.

Ананьин Л.В., Мордвинова В.В. Строение земной коры и верхов мантии вдоль Байкальской рифтовой системы по телесейсмическим данным // Доклады АН. 2012. Т. 444. № 4. С. 440-443.

Ананьин Л.В., Мордвинова В.В., Гоць М.Ф., Канао М., Суворов В.Д., Татьков Г.И., Тубанов Ц.А. Скоростное строение коры и верхней мантии Байкальской рифтовой зоны по долговременным наблюдениям широкополосных сейсмостанций // Доклады АН. 2009. Т. 428. № 2. С. 211-214.

Басов А.Д., Черных Е.Н. О наблюдении среднесрочного предвестника землетрясения в Иркутске // Физика Земли. 2010. № 1. С. 80-89.

Бахмутов В.Г., Гладкочуб Д.П., Шиира В.В. Возрастная позиция, геодинамическая специфика и палеомагнетизм меловых - палеоценовых интрузивных комплексов западного побережья Антарктического полуострова и Аргентинских островов // Геофизический журнал. 2013. № 2. С. 22-31.

Гладкочуб Д.П., Донская Т.В., Вингейт М.Т.Д., Мазукабзов А.М., Писаревский С.А., Корнилова Т.А. Изотопное датирование гибридных пород из зон эндоконтакта как способ выяснения возраста внедрения базитов (южный фланг Сибирского кратона) // Геология и геофизика. 2013. Т. 54. № 11. С. 1714-1730.

Гладкочуб Д.П., Донская Т.В., Иванов А.В., Эрнст Р., Мазукабзов А.М., Писаревский С.А., Ухова Н.А. Фанерозойский базитовый магматизм южного фланга Сибирского кратона и его геодинамическая интерпретация // Геология u геофизика. 2010. Т. 51. № 9. С. 1222-1239.

Гладкочуб Д.П., Донская Т.В., Федоровский В.С., Мазукабзов А.М., Ларионов А.Н., Сергеев С.А. Ольхонский метаморфический террейн Прибайкалья: раннепалеозойский композит фрагментов неопротерозойской активной окраины // Геология и геофизика. 2010. Т. 51. № 5. С. 571-588.

Гладкочуб Д.П., Донская Т.В., Эрнст Р., Мазукабзов А.М., Скляров Е.В., Писаревский С.А., Вингейт М., Седерлунд У. Базитовый магматизм Сибирского кратона в протерозое: обзор основных этапов и их геодинамическая интерпретация // Геотектоника. 2012. № 4. С. 28-41.

Гладкочуб Д.П., Костровицкий С.И., Донская Т.В., ДеВаэле Б., Мазукабзов А.М. Возраст цирконов из алмазоносных лампроитов Восточного Саяна как индикатор известных и ранее не установленных эндогенных событий на юге Сибирского кратона // Доклады АН. 2013. Т. 450. № 5. С. 567-572.

Гладкочуб Д.П., Костровицкий С.И., Донская Т.В., Мазукабзов А.М., ДеВаэле Б. Возраст цирконов из алмазоносных лампроитов Восточного Саяна как индикатор известных и ранее не установленных эндогенных событий на юге Сибирского кратона // Доклады АН. 2013. Т. 450. № 5. С. 567-572.

Гладкочуб Д.П., Николь Г., Станевич А.М., Мазукабзов А.М., Скляров Е.В., Писаревский С.А., Донская Т.В., Тайт Дж. Возраст и источники вещества позднедокембрийских осадочных толщ Южного Прибайкалья: результаты U$\mathrm{Pb}$ (LA-ICP-MS) датирования детритовых цирконов // Доклады АН. 2013. Т. 450. № 3. С. 318-322.

Гладкочуб Д.П., Писаревский С.А., Мазукабзов А.М., Седерлунд У., Скляров Е.В., Донская Т.В., Эрнст Р.Е., Станевич А.M. Первые свидетельства палеопротерозойского постколлизионного базитового магматизма в Присаянском выступе фундамента Сибирского кратона // Доклады АН. 2013. Т. 450. № 4. С. 440-444.

Гладкочуб Д.П., Писаревский С.А., Эрнст Р., Донская Т.В., Седерлунд У., Мазукабзов А.М., Хейнс Дж. Крупная магматическая провинция (КМП) с возрастом 1750 млн лет на площади Сибирского кратона // Доклады АH. 2010. T. 430. № 5. C. 654-657.

Гладкочуб Д.П., Станевич А.М., Мазукабзов А.М., Донская Т.В., Писаревский С.А., Николь Г., Мотова З.Л., Корнилова T.A. Ранние этапы развития Палеоазиатского океана: данные по LA-ICP-MS датированию детритовых цирконов из позднедокембрийских толщ южного фланга Сибирского кратона // Геология и геофизика. 2013. Т. 54. № 10. C. 1472-1490. 
Гладкочуб Д.П., Станевич А.М., Травин А.В., Мазукабзов А.М., Константинов К.М., Юдин Д.С., Корнилова Т.А. Уджинский мезопротерозойский палеорифт (север Сибирского кратона): новые данные о возрасте базитов, стратиграфии и микрофитологии // Доклады АН. 2009. Т. 425. № 5. С. 642-648.

Голубев В.А. Геофизические данные об отсутствии позднекайнозойских мантийных интрузий в земной коре под Байкальской впадиной // Доклады АН. 2009. Т. 426. № 2. С. 235-239.

Голубев В.А. Тепловое поле и глубины очагов землетрясений Байкальской рифтовой зоны // Доклады АН. 2010. T. 433. № 5. С. 641-644.

Гордиенко И.В., Ковач В.П., Елбаев А.Л., Котов А.Б., Сальникова Е.Б., Резницкий Л.З., Яковлева С.З., Анисимова И.В. Возраст и условия формирования коллизионных гранитоидов Джидинской зоны Центрально-Азиатского складчатого пояса, Юго-Западное Забайкалье // Петрология. 2012. т. 20. № 1. С. 45-65.

Давыденко Ю.А., Давыденко А.Ю., Куприянов И.С., Пестерев И.Ю., Попков П.А., Слепцов С.В., Яковлев С.В. Эффект интеграции робастного регрессионного анализа с инверсией для переходных процессов в методе срединного градиента при изучении трубок взрыва на Анабарском щите // Записки горного института. 2013. Т. 200. С. 28-33.

Демонтерова Е.И., Иванов А.В., Карманов Н.С. Базальтовые игнимбритоподобные породы вулкана Сайхан (СевероЗападный Хангай, Монголия) // Вулканология и сейсмология. 2009. № 4. С. 44-52.

Демонтерова Е.И., Иванов А.В., Резницкий Л.З., Беличенко В.Г., Хунг Ц.Х., Чунг С.Л., Иизука Йо., Ванг К.Л. История формирования Тувино-Монгольского массива по данным U-Pb-датирования методом LA-ICP-MS детритовых цирконов из песчаника дархатской серии (Западное Прихубсугулье, Северная Монголия) // Доклады АН. 2011. T. 441. № 3. С. 358-362.

Добрецов Н.Л., Буслов М.М., Де Граве Й., Скляров Е.В. Взаимосвязь магматических, осадочных и аккреционноколлизионных процессов на Сибирской платформе и ее складчатом обрамлении // Геология и геофизика. 2013. T. 54. № 10. С. 1451-1471.

Донская Т.В., Гладкочуб Д.П., Мазукабзов А.М., Пресняков С.Л., Баянова Т.Б. Палеопротерозойские гранитоиды чуйского и кутимского комплексов (юг Сибирского кратона): возраст, петрогенезис и геодинамическая природа // Геология и геофизика. 2013. Т. 54. № 3. С. 371-389.

Донская Т.В., Гладкочуб Д.П., Федоровский В.С., Мазукабзов А.М., Чо М., Чонг В., Ким Дж. Синметаморфические гранитоиды ( 490 млн лет) - индикаторы аккреционной стадии в эволюции Ольхонского террейна (Западное Прибайкалье) // Геология и геофизика. 2013. Т. 54. № 10. С. 1543-1561.

Зорин Ю.А., Скляров Е.В., Беличенко В.Г., Мазукабзов А.М. Механизм развития системы островная дуга - задуговый бассейн и геодинамика Саяно-Байкальской складчатой области в позднем рифее - раннем палеозое // Геология и геофизика. 2009. Т. 50. № 3. С. 209-226.

Иванов А.В. Взаимодействие мантийных расплавов с корой при их подъеме к поверхности: причина и следствие // Геодинамика и тектонофизика. 2012. Т. 3. № 1. С. 19-26.

Иванов А.В., Демонтерова Е.И. Растяжение в Байкальском рифте и глубина формирования базальтовых магм // Доклады АН. 2010. Т. 435. № 4. С. 510-515.

Имаева Л.П.,. Мельникова В.И., Имаев В.С. Сейсмотектоническая деструкции земной коры северо-восточного фланга Байкальской рифтой зоны // Доклады АН. 2012. Т. 443. № 4. С. 492-494.

Кожевников В.М., Соловей О.А. Трехмерная модель мантии Центральной Азии по данным фазовых скоростей волн Рэлея // Вулканология и сейсмология. 2010. № 4. С. 30-39.

Константинов К.М., Томшин М.Д., Гладкочуб Д.П., Васильева А.Е. Палеомагнитные и петрогеохимические исследования раннемезозойских базитов бассейна р. Уджа (северо-восток Сибирской платформы) // Литосфера. 2012. № 3. С. 80-98.

Котов А.Б., Мазукабзов А.М., Сковитина Т.М., Великославинский С.Д., Сорокин А.А., Сорокин А.П. Структурная эволюция и геодинамическая позиция Гонжинского блока (Верхнее Приамурье) // Геотектоника. 2013. № 5. C. $48-60$.

Котов А.Б., Мазукабзов А.М., Сковитина Т.М., Сорокин А.П., Великославинский С.Д., Сорокин А.А. Структурная эволюция Гонжинского блока Аргун-Идермегского супертеррейна Центрально-Азиатского складчатого пояса // Доклады АН. 2013. Т. 448. № 5. С. 563-566.

Левицкий В.И., Резницкий Л.З., Сальникова Е.Б., Левицкий И.В., Котов А.Б., Бараш И.Г., Яковлева С.З., Анисимова И.В., Плоткина Ю.В. Возраст и происхождение Китойского месторождения силлиманитовых сланцев (Восточная Сибирь) // Доклады АН. 2010. Т. 431. № 3. С. 386-391.

Лысак С.В. Термальная эволюция, геодинамика и современная геотермальная активность литосферы Китая // Геология и геофизика. 2009. Т. 40. № 9. С. 1058-1071.

Мазукабзов А.М., Донская Т.В., Гладкочуб Д.П., Падерин И.П. Геодинамика Западно-Забайкальского сегмента Центрально-Азиатского складчатого пояса в позднем палеозое // Геология и геофизика. 2010. Т. 51. № 5. С. 615-628.

Мазукабзов А.М., Скляров Е.В., Донская Т.В., Гладкочуб Д.П., Федоровский В.С. Комплексы метаморфических ядер Забайкалья: обзор // Геодинамика и тектонофизика. 2011. Т. 2. № 2. С. 95-125.

Мельникова В.И., Гилева Н.А., Арефьев С.С., Быкова В.В., Середкина А.И. Култукское землетрясение 2008г. с $M_{\mathrm{w}}=6.3$ на юге Байкала: напряженно-деформированное состояние очаговой области по данным об афтершоках // Физика Земли. 2013. № 4. С. 1-15. 
Мельникова В.И., Гилева Н.А., Имаев В.С., Радзиминович Я.Б., Тубанов Ц.А. Особенности сейсмических активизаций Среднего Байкала в 2008 - 2011 годах // Доклады АН. 2013. Т. 453. № 6. С. 1-6.

Мельникова В.И., Гилева Н.А., Масальский О.К., Радзиминович Я.Б., Радзиминович Н.А. К вопросу об условиях генерации сильных землетрясений в Южном Байкале // Доклады АН. 2009. Т. 429. № 3. С. 1-5.

Мельникова В.И., Радзиминович Я.Б., Гилева Н.А., Радзиминович Н.А., Папкова А.А. Балейское землетрясение 6 января 2006 г.: отражение современной тектонической активности Восточного Забайкалья // Доклады АН. 2011. T. 437. № 6. C. 828-832.

Мордвинова В.В., Артемьев А.А. Трехмерная модель юга Байкальской рифтовой зоны и сопредельных территорий по объемным волнам // Геология и геофизика. 2010. Т. 51. № 6. С. 887-904.

Наговицин К.Е., Станевич А.М., Корнилова Т.А. Стратиграфическое положение и возраст комплекса TAPPANIA содержащих протерозойских ископаемых биот Сибири // Геология и геофизика. 2010. Т. 51. № 11. С. 1531-1538.

Немеров В.К., Станевич А.М., Развозжаева Э.А., Будяк А.Е., Корнилова Т.А. Биогенно-седиментационные факторы рудообразования в неопротерозойских толщах Байкало-Патомского региона // Геология и геофизика. 2010. Т. 51. № 5. С. 729-747.

Патон М.Т., Иванов А.В., Фиорентини М.Л., МакНаугтон Н.Ж., Мудровская И., Резницкий Л.З., Демонтерова Е.И. Позднепермские и раннетиасовые магматические импульсы в Ангаро-Тасеевской синклинали, Южно-Сибирские траппы и их возможное влияние на окружающую среду // Геология и геофизика. 2010. Т. 51. № 9. С. 1298-1309.

Радзиминович Н.А., Очковская М.Г. Выделение афтершоковых и роевых последовательностей землетрясений Байкальской рифтовой зоны // Geodynamics \& Tectonophysics. 2013. Т. 4. № 2. С. 169-186.

Радзиминович Я.Б., Мельникова В.И., Середкина А.И., Гилева Н.А., Радзиминович Н.А., Папкова А.А. Землетрясение 6 января 2006 г. (Mw=4.5): редкий случай проявления сейсмической активности в Восточном Забайкалье // Геология и геофизика. 2012. Т. 53. № 10. С. 1430-1444.

Резницкий Л.З., Скляров Е.В., Армбрустер Т., Ущаповская З.Ф., Галускин Е.В., Полеховский Ю.С., Бараш И.Г. Новый минерал оксиванит $\mathrm{V}_{3} \mathrm{O}_{5}$ и изоморфный ряд оксиванит-бердесинскиит $\mathrm{V}_{2} \mathrm{TiO}_{5}$ в метаморфических породах слюдянского комплекса (Южное Прибайкалье) // Записки РМО. 2009. № 3. С. 70-81.

Резницкий Л.з., Скляров Е.В., Галускин Е.В. Непрерывный изоморфный ряд диопсид-космохлор $\mathrm{CaMgSi}_{2} \mathrm{O}_{6}-$ $\mathrm{NaCrSi}_{2} \mathrm{O}_{6}$ в метаморфических породах слюдянского комплекса // Геология и геофизика. 2011. Т. 52. № 1. C. 51-65.

Резницкий Л.З., Скляров Е.В., Ущаповская З.Ф., Суворова Л.Ф., Полеховский Ю.С., Дзержановский П., Бараш И.Г. Купрокалининит $\mathrm{CuCr}_{2} \mathrm{~S}_{4}$ - новая сульфошпинель из метаморфических пород слюдянского комплекса (Южное Прибайкалье) // Записки РМО. 2010. № 6. С. 65-75.

Резницкий Л.З., Скляров Е.В.,. Армбрустер Т, Суворова Л.Ф., Ущаповская 3.Ф., Канакин С.В. Кызылкумит: находка в Южном Прибайкалье (Россия), уточнение кристаллохимической формулы // Записки РМО. 2013. № 2. С. 107120.

Резницкий Л.З., Травин А.В., Беличенко В.Г., Школьник С.И., Бараш И.Г., Летникова Е.Ф. ${ }^{40} \mathrm{Ar} /{ }^{39} \mathrm{Ar}$ возраст полифациального метаморфизма осадочно-вулканогенных толщ Тункинских Гольцов (Восточный Саян) // Доклады АН. 2013. T. 448. № 6. С. 684-688.

Сапожников А.Н., Канева Е.В., Черепанов Д.И., Суворова Л.Ф., Левицкий В.И., Иванова Л.А., Резницкий Л.З. Владимиривановит $\mathrm{Na}_{6} \mathrm{Ca}_{2}\left[\mathrm{Al}_{6} \mathrm{Si}_{6} \mathrm{O}_{24}\right]\left(\mathrm{SO}_{4}, \mathrm{~S}_{3}, \mathrm{Cl}\right)_{2} \cdot \mathrm{H}_{2} \mathrm{O}$ - новый минерал из группы содалита // Записки РМО. 2011 . № 5. С. $36-45$.

Середкина А.И. Скоростные неоднородности земной коры и верхней мантии и сейсмические структуры центральной части Азии: Автореф. дис. ... канд. физ.-мат. наук. Иркутск. 2013. 22 с.

Середкина А.И., Мельникова В.И. Тензор сейсмического момента прибайкальских землетрясений по поверхностным волнам // Доклады АН. 2013. Т. 451. № 1. С. 91-94.

Скляров Е.В., Солотчина Э.П., Вологина Е.Г., Игнатова Н.В., Изох О.П., Кулагина Н.В., Склярова О.А., Солотчин П.А., Столповская Н.В., Ухова Н.Н., Федоровский В.С., Хлыстов О.М. Детальная летопись климата голоцена из карбонатного разреза соленого озера Цаган-Тырм (Западное Прибайкалье) // Геология и геофизика. 2010. Т. 51. № 3. С. 303-328.

Скляров Е.В., Федоровский В.С., Котов А.Б., Лавренчук А.В., Мазукабзов А.М., Левицкий В.И., Сальникова Е.Б., Старикова А.Е., Яковлева С.З., Анисимова И.В., Федосеенко А.М. Карбонатиты в коллизионных обстановках и квазикарбонатиты Ольхонской коллизионной системы // Геология и геофизика. 2009. Т. 50. № 12. С. 1405-1423.

Скляров Е.В., Федоровский В.С., Котов А.Б., Лавренчук А.В., Мазукабзов А.М., Старикова А.Е. Инъекционные карбонатные и силикатно-карбонатные комплексы в коллизионных системах на примере Западного Прибайкалья, Россия) // Геотектоника. 2013. № 3. С. 58-77.

Станевич А.М., Мазукабзов А.М., Корнилова Т.А., Максимова Е.Н. Минерализованная микробиота улунтуйской свиты неопротерозоя // Литология и полезные ископаемые. 2012. № 1. С. 98-107.

Станевич А.М., Максимова Е.Н., Корнилова Т.А., Гладкочуб Д.П., Мазукабзов А.М., Донская Т.В. Микрофоссилии арымасской и дебенгдинской свит рифея Оленекского поднятия: возраст и предполагаемая природа // Стратиграфия. Геологическая корреляция. 2009. № 1. С. 45-58. 
D.P. Gladkochub, E.Kh. Turutanov: The deep structure and paleogeodynamics of Siberia and Central Asia...

Турутанов Е.X. Ангаро-Витимский батолит: форма и размеры по гравиметрическим данным // Доклады АН. 2011. T. 440. № 6. С. 815-818.

Турутанов Е.X. Состав и морфология крупных плотностных неоднородностей земной коры - фактор влияния на сейсмическую активность // Отечественная геология. 2012. № 3. С. 66-72.

Федоровский В.С., Скляров Е.В. Ольхонский геодинамический полигон (озеро Байкал): аэрокосмические данные высокого разрешения и геологические карты нового поколения // Геодинамика и тектонофизика. 2010. Т. 1. № 4. C. 331-418.

Федоровский В.С., Скляров Е.В., Изох А.Э., Котов А.Б., Лавренчук А.В., Мазукабзов А.М. Сдвиговый тектогенез и щелочно-базитовый магматизм в коллизионной системе каледонид Западного Прибайкалья // Геология и геофизика. 2010. Т. 51. № 5. С. 682-700.

Школьник С.И., Бараш И.Г., Беличенко В.Г., Летникова Е.Ф. Высокоглиноземистые венд-кембрийские отложения Тункинских гольцов (Восточный Саян) // Доклады АН. 2011. Т. 436. № 2. С. 253-257.

Школьник С.И., Беличенко В.Г., Резницкий Л.з. Высокомагнезиальные пикрит-базальтовые ассоциации Тункинского террейна (Байкало-Хубсугульский регион) как индикатор спрединга окраинного бассейна // Геология и геофизика. 2013. № 2. С. 203-218.

Школьник С.И., Беличенко В.Г., Резницкий Л.З., Бараш И.Г. Фрагмент зоны задугового палеоспрединга в Тункинском террейне // Доклады АН. 2011. Т. 436. № 1. С. 109-113.

Школьник С.И., Резницкий Л.З., Бараш И.Г. Возможность диагностики задуговых палеобассейнов по высокоградным ортометаморфитам (на примере основных кристаллосланцев Слюдянского кристаллического комплекса, Южное Прибайкалье) // Геохимия. 2011. № 12. С. 1253-1257.

Школьник С.И., Резницкий Л.З., Беличенко В.Г., Бараш И.Г. Геохимия, вопросы петрогенезиса и геодинамическая типизация метавулканитов Тункинского террейна (Байкало-Хубсугульский регион) // Геология и геофизика. 2009. T. 50. № 9. С. 1013-1024.

Шохонова М.Н., Донская Т.В., Гладкочуб Д.П., Мазукабзов А.М., Падерин И.П. Палеопротерозойские базальтоиды Северо-Байкальского вулканоплутонического пояса Сибирского кратона: возраст и петрогенезис // Геология $u$ геофизика. 2010. Т. 51. № 8. С. 1049-1072.

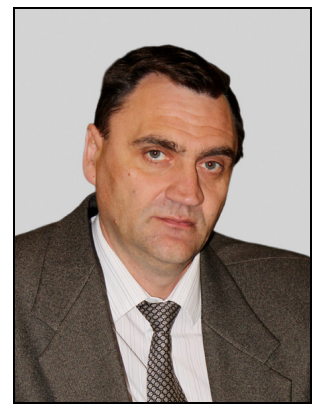

Гладкочуб Дмитрий Петрович, докт. геол.-мин. наук, директор института Институт земной коры СО РАН

664033, Иркутск, ул. Лермонтова, 128, Россия

\e-mail: dima@crust.irk.ru

Gladkochub, Dmitry P., Doctor of Geology and Mineralogy, Director of the Institute Institute of the Earth's Crust, Siberian Branch of RAS

128 Lermontov street, Irkutsk 664033, Russia

$\triangle$ e-mail: dima@crust.irk.ru

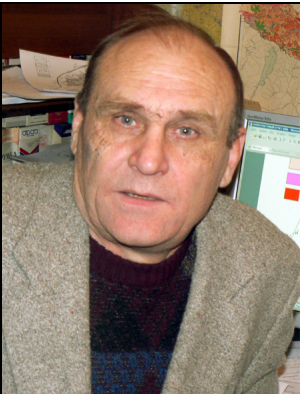

Турутанов Евгений Хрисанфович, канд. геол.мин.наук, зав. лабораторией комплексной геофизики Институт земной коры СО РАН

664033, Иркутск, ул. Лермонтова, 128, Россия

Тел.: 8(3952)428792; email: tur@crust.irk.ru

Turutanov, Evgeni Kh., Candidate of Geology and Mineralogy, Head of Laboratory of integrated Geophysics Institute of the Earth's Crust, Siberian Branch of RAS

128 Lermontov street, Irkutsk 664033, Russia

Tel.: 8(3952)428792; email: tur@crust.irk.ru 